\title{
THE IMPACT OF TRANSLATION STRATEGIES ON SECOND LANGUAGE WRITING
}

A dissertation submitted

to Kent State University in partial

fulfillment of the requirements for

the degree of Doctor of Philosophy

by

Carine Graff

August 2018

(C) Copyright

All rights

reserved

Except for previously published materials 


\section{Dissertation written by}

\section{Carine Graff}

Licence, University of Mulhouse, 1999

Maîtrise, University of Mulhouse, France, 2001

M.A., University of Wisconsin-Milwaukee, 2011

Ph.D., Kent State University, 2018

Approved by

$\underline{\text { Richard Washbourne, }}$ Chair, Doctoral Dissertation Committee

Erik Angelone __ Members, Doctoral Dissertation Committee

$\underline{\text { Brian Baer }}$

Sarah Rilling

$\underline{\text { Sara Newman }}$

Accepted by

Keiran Dunne ___ Chair, Department of Modern and Classical Language Studies

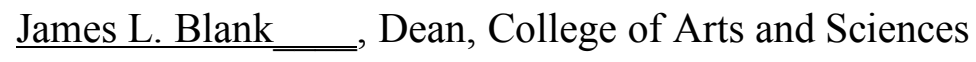




\section{TABLE OF CONTENTS}

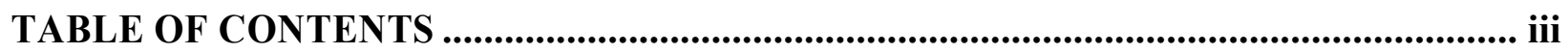

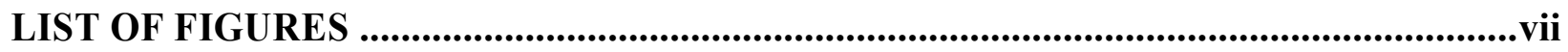

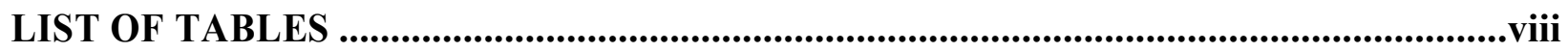

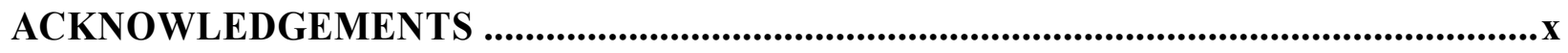

Chapter 1: Introduction ...........................................................................................................

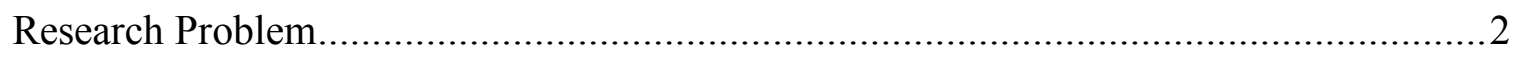

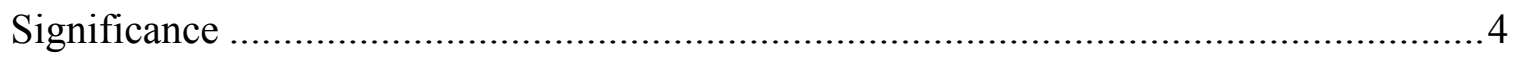

Scholars who are for the use of translation in FL classrooms.........................................

Scholars who are against the use of translation in FL classrooms................................... 5

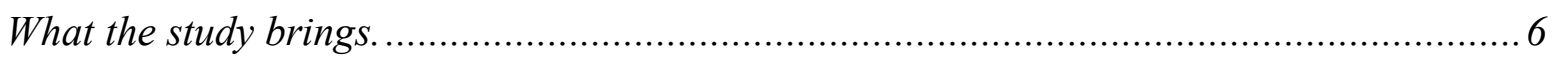

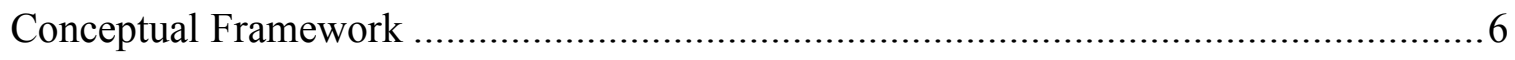

How to teach L2 writing in the foreign language classroom. .......................................... 6

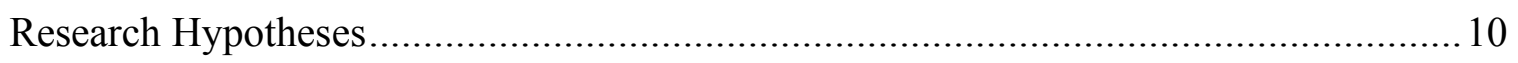

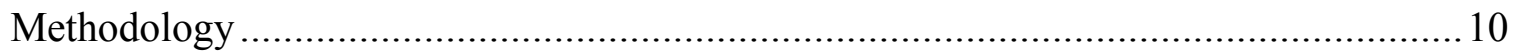

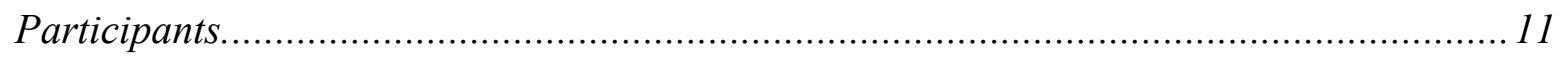

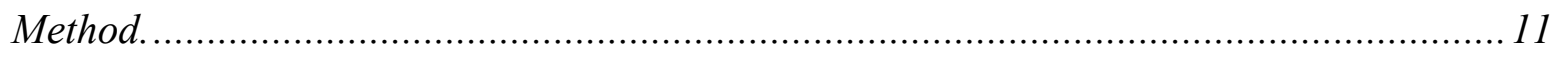

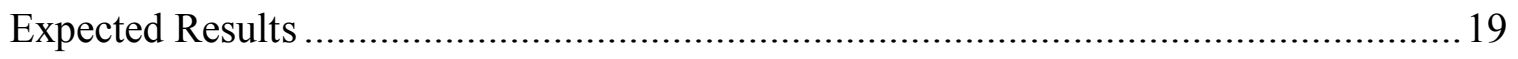

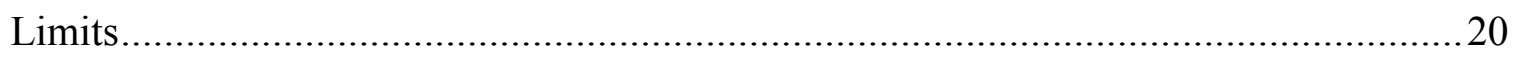

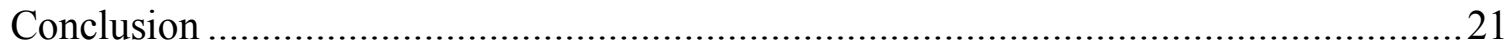

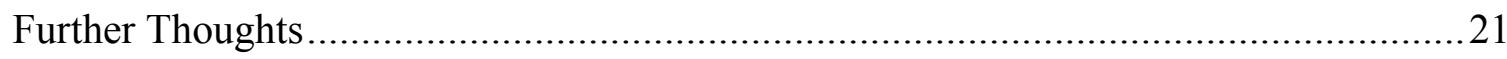

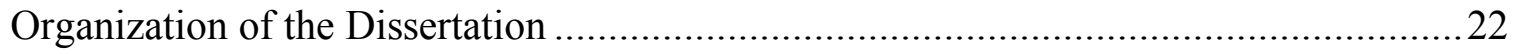

Chapter 2: Literature Review ....................................................................................................23 
What is Translation?.

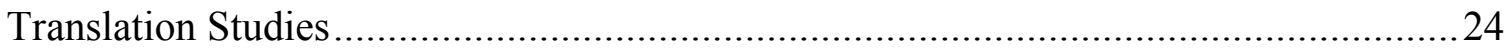

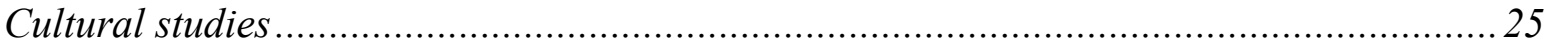

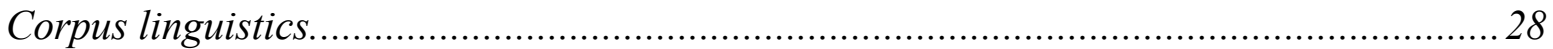

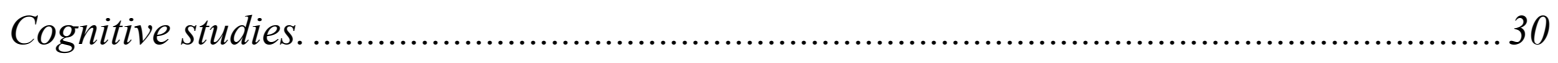

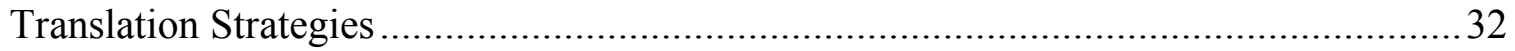

Translation and Second Language Acquisition ....................................................... 38

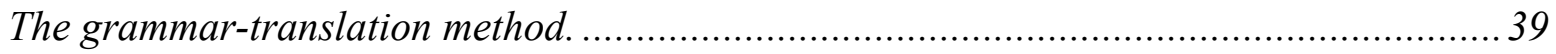

Ban of grammar-translation method and rise of the communicative method.................... 40

The positive use of the $L 1$ in the foreign language classroom...................................... 44

The Return of Translation in the Foreign Language Classroom (Pedagogical Translation) .

Scholars who are against, and scholars who are for, the use of translation.................... 49

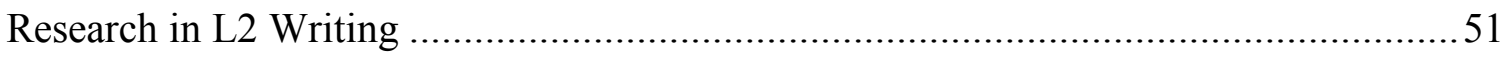

Chapter 3: Methodology ......................................................................................................55

Classes and Selection of Participants .................................................................. 55

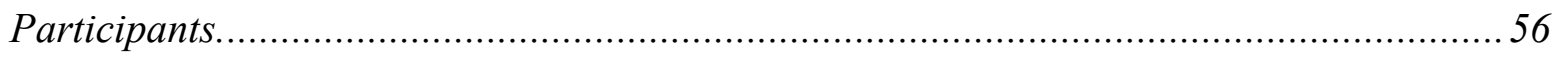

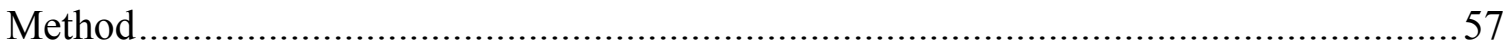

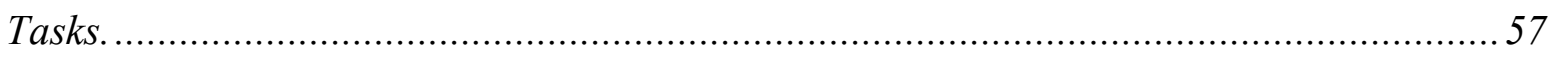

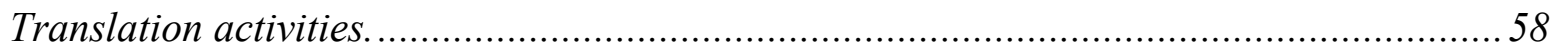

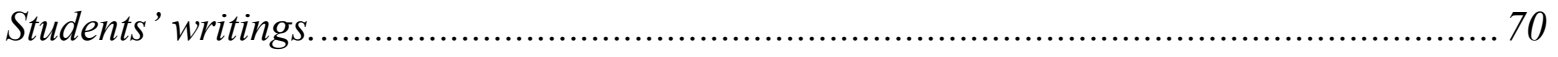

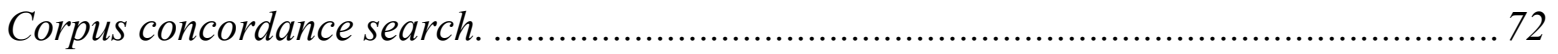

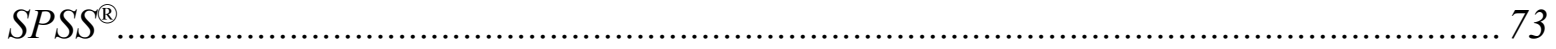


Chapter 4: Results and analysis ...........................................................................76

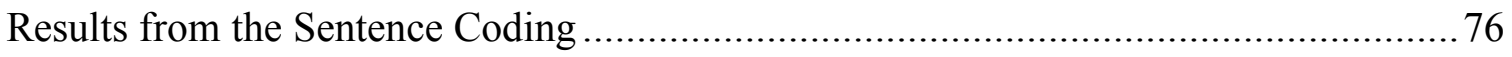

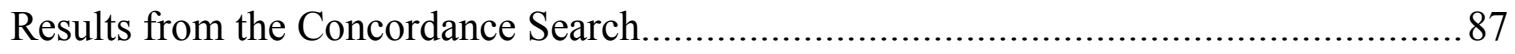

Results from the Statistical Analysis............................................................ 90

Chapter 5: Conclusion .................................................................................................95

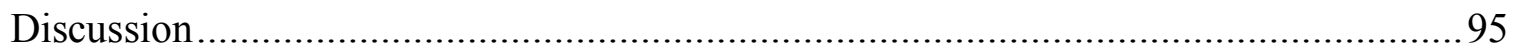

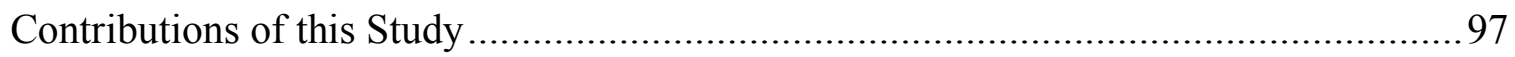

Translation and $L 2$ reading skills - The reading/writing relationship........................... 99

Relationship between translation and creative writing: translators are writers.............. 104

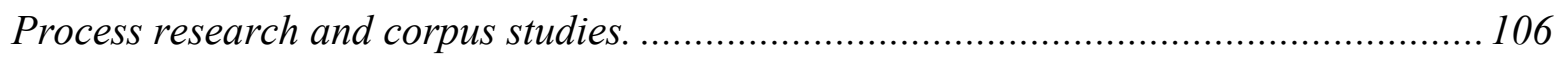

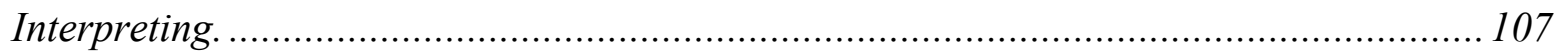

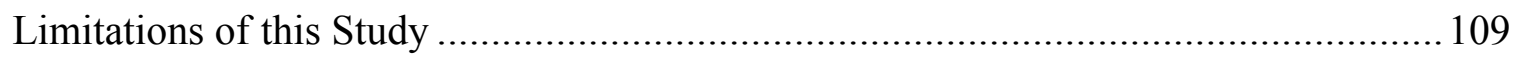

Recommendations for Further Research ................................................. 112

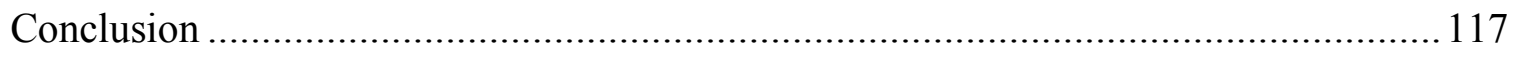

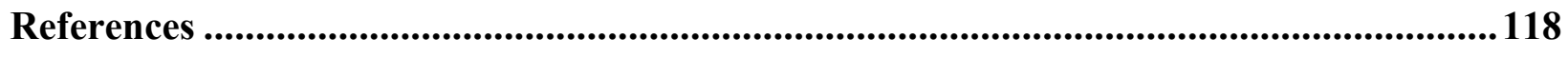

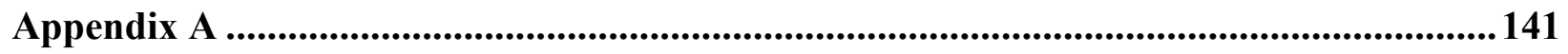

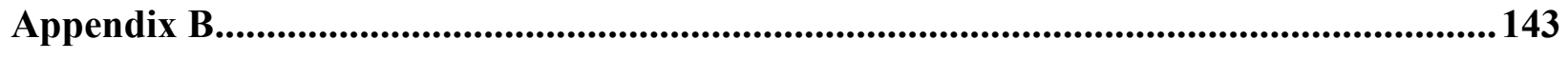

Appendix C ...........................................................................................................................150

Appendix D ................................................................................................................ 158

Appendix E....................................................................................................................... 166

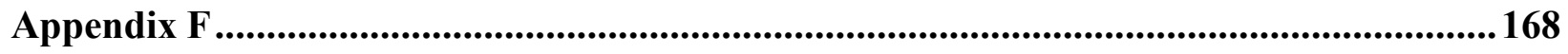

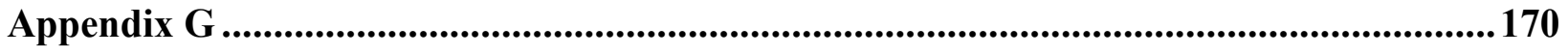

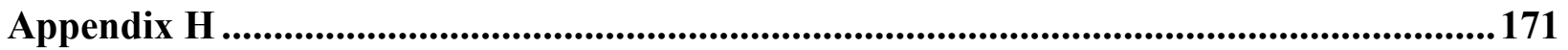


Appendix I................................................................................................................... 172

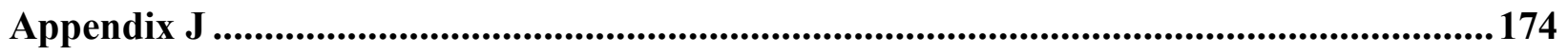

Appendix K K..............................................................................................................175

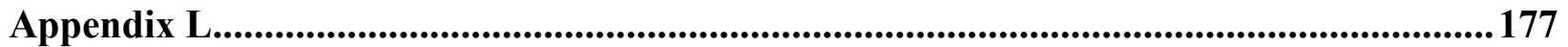




\section{LIST OF FIGURES}

Figure 1. Screen shot showing collocations for the French verb "marier" .............................. 14

Figure 2 Example of concordance search for the verb "s'appeler" ....................................... 73

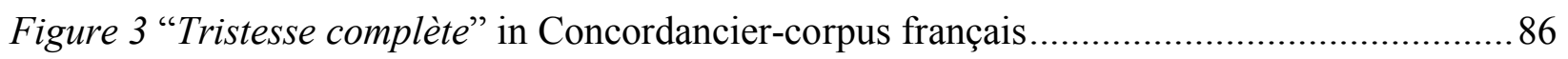

Figure 4 "à sa maison" in Concordancier-corpus français ................................................ 86

Figure 5 "près de la fin" in Concordancier-corpus français ................................................. 86

Figure 6 Intertwined Language Processing Types ........................................................ 103

Figure 7 Diagram showing the links between the sub competences of translation and second

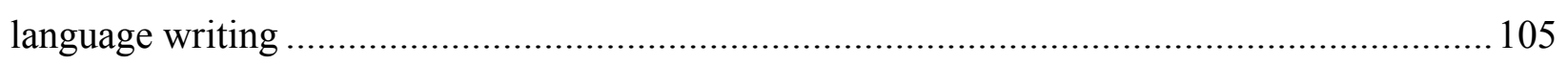

Figure 8 Venn Diagram representing Translation Studies and its sub-competences................ 108

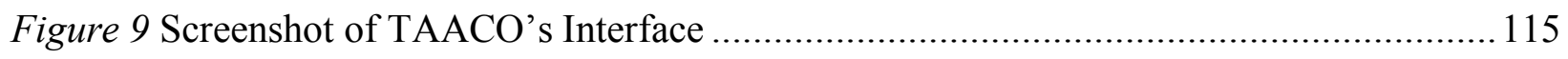




\section{LIST OF TABLES}

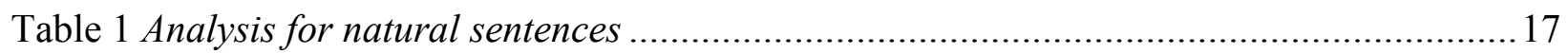

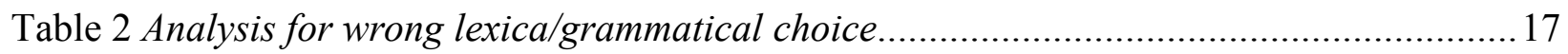

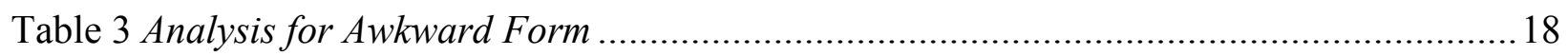

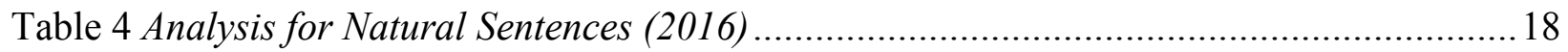

Table 5 Analysis for Wrong Lexical/Grammatical Choice (2016) .......................................... 18

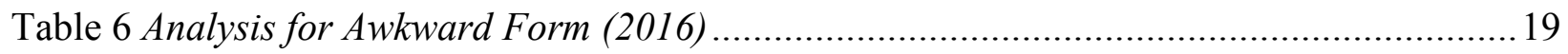

Table 7 Adapted from Vinay and Darbelnet's Main Translation Procedures Listed in Increasing

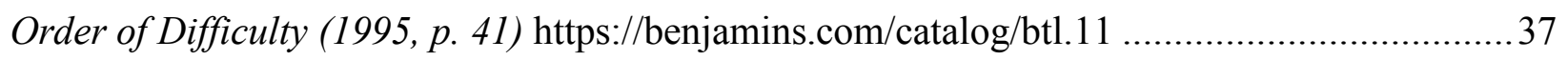

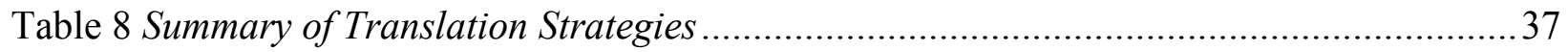

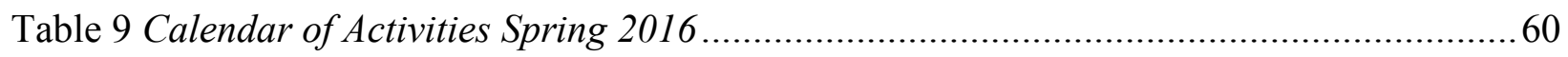

Table 10 Total Number of Lexical/grammatical Choice Errors, Deviant sentences, Natural

Sentences, Sentences, and Words before and after (Fall 2014) ..........................................76

Table 11 Total Number of Lexica/grammatical l Choice Errors, Deviant sentences, Natural

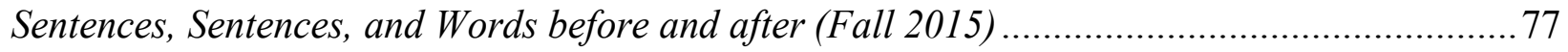

Table 12 Total Number of Lexical/grammatical Choice Errors, Deviant sentences, Natural

Sentences, Sentences, and Words before and after (Spring 2016) ....................................... 78

Table 13 Total Number $\langle L 1 M>$, $<N G>$, and $<G A>$ in the Whole Corpus ........................... 78

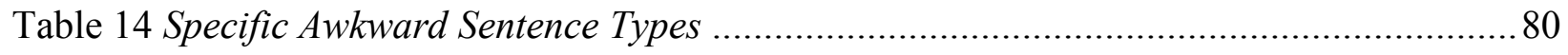

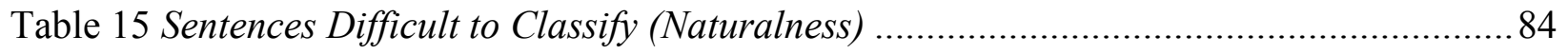

Table 16 Excerpt of Concordance Search Results for the Fall 2014 Class' First Composition .. 88

Table 17 Mean and Standard Deviation Before and After ................................................ 91 
Table 18 Similarities Between Experts in L2 Writing and Experts in Translation in the Way They

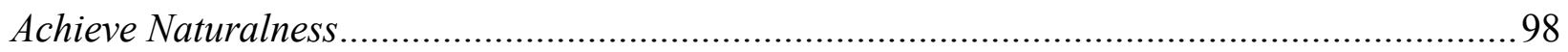

Table 19 Similarities Between Second Language Writing and Translating .............................. 98 Table 20 Knowledge Categories Common to Readers and Writers (After Fitzgerald and

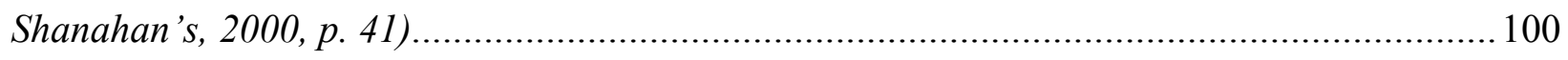

Table 21 Similarities: Reading for Comprehension and Reading for Translation ................... 102 


\section{ACKNOWLEDGEMENTS}

I would like to thank Dr. Richard Kelly Washbourne, who mentored me during this study, as well as all the committee members including Dr. Erik Angelone, Dr. Brian Baer, Dr. Sarah Rilling, and Dr. Sara Newman for their valuable suggestions, help, and guidance. I am grateful for the Department of Modern \& Classical Language Studies and the Institute for Applied Linguistics at Kent State University for the financial support offered during my doctoral studies. I also would like to express my gratitude to Dr. Isabel Lacruz and the Research and Evaluation Bureau at Kent State University for their help with the statistical analysis. And

finally, I would like to thank all my colleagues, friends, and family, who supported me during this long journey. 


\section{Chapter 1: Introduction}

This dissertation presents a study that proposes to test whether the introduction of translation strategies as informed by Translation Studies in the foreign language classroom affects second language writing. For a long time after the demise of the grammar translation method in the 1980s, translation was banned from the foreign or second language classroom (Cook, G., 2007). Translation was seen as a mere mechanical device used in pedagogical drills to consolidate grammar structures in the foreign or second language or to serve as a comprehension check. It has been considered as a hindrance to the communicative method that sees language as a communicative device and seeks to make the classroom conducive to active communication in the foreign/second language (Machida, 2011). After almost three decades, however, translation is beginning to return to foreign language classrooms. A few studies such as Károly (2014) and González Davies' (2014) have shown that, far from being a hindrance to foreign language acquisition, translation may help learners of a foreign language improve their grammar and enhance their cultural understanding in the foreign language (Machida, 2011). The current study aims to map how translation, as perceived in Translation Studies, can be beneficial for students' writing skills in the foreign language classroom. It focuses on undergraduate students in three French Composition classes: a first control class in the Fall of 2014 in which no translation task and strategy was introduced, a second control class in the Fall of 2015 in which one translation task and strategy was introduced, and an experimental class in the Spring of 2016, in which more than two translation tasks and strategies were introduced-via their formal introduction followed 
by translationtasks—such as explicitation, amplification, modulation (Vinay \& Darbelnet, 1984), and approaches, such as Skopos theory (skopos means purpose in Greek; a translation has a purpose) (Vermeer, 1983). It explored the effect of these exercises on the students' writing. The progress of students was evaluated with the first and last compositions students produced in the two control classes. Then, in the experimental class, the students wrote a summary of the novel read in class, and after being exposed to translation strategies, they were tasked with writing another summary. To determine whether translation strategies enabled students to improve naturalness in second language (L2) writing, their summaries were error coded using Kobayashi \& Rinnert's (1992) method of awkward form and wrong lexical/grammatical choice, McCarthy's (2015) collocation search, and Owen's (1988) native speaker input. All the steps of the analysis were undertaken by the investigator and a second reader. The aim of the study is to empirically document the effect if any, of translation exercises on the acquisition of foreign language writing proficiency.

\section{Research Problem}

In the literature, some studies have shown that students writing in their L2 depend on their native language (L1), for example, at the draft stage when they are looking for ideas (Hayes \& Chenowith, 2001; Lifang, 2008). In the L2 control writing class French Composition and French Composition Extended at Kent State University—Fall 2015, it was noticeable that students relied on their mother tongue (English), but not isolated to the draft stage. In fact, some students wrote in the L2 (French) while using the syntax of their L1, which resulted in incoherent sentences in the L2. A probable cause behind this issue is that students translate mentally while writing in the L2, as demonstrated in Kobayashi and Rinnert's study (1992). If students translate 
mentally word for word, one solution would be to help them think in the L2, and to do so by introducing them to translation strategies that would prevent them from translating word for word mentally, and thus achieve more natural writing. Translation strategies are methods used by translators when they encounter a translation problem, such as translating an idiom. These can be conscious or unconscious procedures: the level of awareness depends on the level of expertise of the translator; for example, an expert, unlike a novice, will use those strategies automatically without thinking about them (Kaiser-Cooke, 1994). Different translation strategies essentially Vinay and Darbelnet's indirect strategies which enable to avoid structural parallelism as opposed to literal translation, which is a direct translation strategy mimicking structural parallelism from the source language to the target languagewill be presented below, but as a brief example we can consider transposition, which is a shift in the grammatical category from one language to the other: "Dès son lever (noun) $\rightarrow$ As soon as he gets up (verb)" (Vinay \& Darbelnet, 1984, p. 50). Those translation strategies authorize students to move away from a word for word translation. The present study will address the following research questions:

1) How does the introduction of translation strategies affect students' L2 writing?

2) Specifically, is students' L2 writing more natural after the introduction of translation strategies?

The goal of the study is to answer these questions via analysis of the work of students in three sections of a French composition class with different cohorts: two control classes (Fall 2014, and Fall 2015), and an experimental class (Spring 2016). 


\section{Significance}

The literature is lacking examples of studies that closely link Translation Studies and second language acquisition, especially second language writing. There are in fact two schools of thought: scholars who think that translation might hinder the improvement of students' L2 writing, and scholars who think that translation can improve it. These two groups include scholars from Second Language Acquisition (SLA), who perceive translation as "pedagogical translation," as well as scholars from Translation Studies who perceive translation from a Translation Studies perspective as an integral part of communication (Jakobson, 1959). In both disciplines, there are mixed opinions as to whether translation should be used in the foreign language classroom.

\section{Scholars who are for the use of translation in FL classrooms.}

Machida (2011) points out that translation can be a beneficial tool in the L2 classroom to help improve form, and meaning, allowing students to transfer a message correctly. The act of translating enables learners to understand errors, and address them at a higher cognitive level, instead of eliminating them in their language output, as in the AudioLingual method for example (Machida, 2011). Moreover, in Machida's study, which included writing in the L2 (direct composition) as well as writing in the L1 and then translation into the L2, Kobayashi and Rinnert (1992), demonstrate that students use their L1 in a helpful way while writing in the L2, especially to generate ideas. For Adrienn Károly, a functional approach, and some aspects of translation as taught for professional purposes, can be useful in the language classroom: "source text analysis, text comprehension, specific translation problems and translation strategies (grammatical and lexical transfer operations), specialized vocabulary, cohesion, the use of resources, revision (self or peer revision), EU-related background knowledge or the analysis of 
authentic target texts” (Károly, 2014 p.103). In The Translator as Writer (Bassnett \& Bush, 2006) Susan Bassnett argues that translation can help students learn how to write, as translating pushes the translator to speak different voices, as one translates different authors, and in that manner is more likely to then find one's own voice (Bassnett \& Bush, 2006).

\section{Scholars who are against the use of translation in FL classrooms.}

However, Kobayashi and Rinnert (1992) also found that relying too much on the L1 could hinder improvement in L2 writing (Kobayashi and Rinnert, 1992). According to them, students should write for the L2 audience, but using too much translation can inhibit secondlanguage writing fluency and prevent the students from developing an awareness of the second language audience's expectations (Kobayashi and Rinnert, 1992). For Christina Schäffner, translation used in language classrooms, and translation used in the industry are two different entities ( Schäffner, 1998): translation used for language purposes is a reproduction of the meaning of the source text while concentrating on grammatical forms, whereas translation for professional purposes is the production of text for a specific goal.

This is where the present study comes in. Students may translate mentally, and that cannot be prevented, so why not offer them tools to do so properly? Why not see translation, as it is presented in Translation Studies, as a means to communicate meaning to a target audience? Writing and translating are similar, for instance, in that one should consider the audience when translating and when writing (Cumming, 1989). The present study will try to test some of these scholars' assertions, and to refocus tasks toward functional ends, as well as show that translation in the language classroom can not only be used in a similar way as when taught in translator training and education, but also that translation can help enhance L2 learners' writing. 


\section{What the study brings.}

Identifying if or in what way translation strategies can improve second language writing would not only facilitate the idea of re-introducing translation in the language classroom, but also presenting it as a tool to improve students' writing in another perspective than when translation was used during the grammar method period, and to encourage colleagues to use it more in class. Translation would be a means to help students develop their second language writing skills, as well as their cultural knowledge, as it broadens the perspective of students being cultural communicators and mediators (Katan, 2009).

\section{Conceptual Framework}

\section{How to teach $\mathrm{L} 2$ writing in the foreign language classroom.}

Quite a lot has been written on how to teach second language writing, and the debate is still going on as to what the best method would be. There are mainly three theoretical orientations that govern the methods of teaching writing: text-focused, process-focused, and sociocultural methods (Barkaoui, 2007).

Text-oriented research focuses on the features of the text produced by the learners. Process-oriented research concentrates on planning, as well as content, form, and syntax (Cumming, 2001). For instance, according to Roca, Murphy, Marin, and Ariel (2002), writers have to acquire these behaviors:

The ability to manage complex mental representations, the ability to construct rhetorical and organizational goals and hold them in mind while composing, the efficient use of problem-solving procedures in order to formulate their texts, the ability to distinguish between editing and revision as two different operations distributed in different stages of 
the composition process, and the adoption of a flexible attitude toward the use of rhetorical devices (p. 27).

Sociocultural research focuses on genres, values and practices of the target audience (Barkaoui, 2007).

\section{How to use those methods in the foreign language classroom.}

In the foreign language classroom, process modeling can be used to show students how a process is performed. It gives examples to students of "how to". Text modeling, in text-focused and sociocultural orientations, which are used to teach students explicitly about L2 target texts, is a method that consists of concentrating on the purpose of the text, and the audience. It is a mix of both: text forms (grammar, vocabulary), and a broader view of context, and purpose. The reason a text is written, and how, can be explored in the foreign language class with reading activities. Consistent with this view, data from this study are based on students' thorough reading of Pierre Loti's Pêcheur d'Islande (1886): analysis of discourse, work on questions about the form and content of the text. Hyland (2002) (as cited in Barkaoui, 2007, p. 35), suggests that analysis of target texts can familiarize students with rhetorical conventions. The idea of text-analysis, and focus on the audience are relevant for this study, as they echo text analysis in Translation Studies.

\section{Methods used in translator training and education.}

Indeed, these theoretical orientations and methods can very well be compared to what is also used in translator training and education. There are many similarities. As regards textfocused, and sociocultural methods for example, text types are used in translator training to help determine not only the tone of the text, but also the audience (Nord, 1991). Similarly, to what can happen in SLA training, translator trainers focus analytical competence activities on the 
target audience, as the target text might need some adequacy depending on the norms, customs, and ethics of the target audience. The text has a purpose for this audience, and it needs to be determined in order for its message to be understood by the target audience as well as possible. A certain text type has a purpose (Nord \& Sparrow, 1991), which is called the "skopos"-Greek word for aim or purpose-and stems from Skopos Theory in Translation Studies by Hans Vermeer and Katharina Reiss (Reiss, K. Vermeer, 2014).

When tasked with deciding on their target audience, translation students in an introductory translation class usually have a hard time thinking of it and remembering that there is an audience that needs attention. That is why it is useful to have the learners perform a pretask during which they answer questions before they start translating. Once they have read the source text to translate, they can try to answer questions such as: what type of text is it (informative, expressive, operative)? What is its purpose? What is the register used? For whom are they translating? Students can reflect on these questions, and decide what tone to give their translation, which register to use, and which translation strategies to use. In an introductory class, these questions must be answered every time the learners translate a text. The question "Who are you translating for?" can be answered as a personal answer if the students decide who their audience is. However, the question can also be answered according to the brief - or instructions given, usually by the client in the translation industry. In class, the professor can give a translation brief that orientates the students toward their audience or the student can provide one or more.

Of course, in translation, the starting point is a text that is already available, whereas in SLA, when students write, they create their text from scratch: there is no primary physical text to which they can refer. The text students refer to is inscribed in their heads; it is a mental 
representation of ideas, which they think about in English most of the time. In direct

composition, the notion of intercultural text transfer is not present, but the notion of intercultural communication definitely is, which includes communicating in another language keeping in mind the cultural background such as customs and expectations of the target audience, as student writers need to communicate their ideas in another language in the foreign language class (Popescu, 2013).

In Translation Studies, process-oriented research is concentrating on how translators translate. Attempts to capture how it happens are often made with Think Aloud Protocols (TAPs), as they enable researchers to discover what the translator might be thinking while translating. The translation process in Translation Studies can also be analyzed while looking at the translation strategies used by the translator such as explicitation, transposition, or modulation for example (Lörscher, 2002).

\section{Similarities: how all of these methods can be used together (the methods as well as translation strategies) for common goals, which are naturalness in L2 writing.}

Similarities are found in how writing is approached in SLA and how translating is approached in Translation Studies (TS). Text modeling, in text-focused and sociocultural orientations can be used in SLA, as well as in translator training. When translation is used in the foreign language classroom, modeling can be very effective in showing students the differences between source and target text syntax for example. 


\section{Research Hypotheses}

The independent variable is the use of the first language (L1) by the students while writing. The dependent variable is the students' writing or their syntax. The research hypotheses can be stated as follows:

1. Translation strategies-which have been defined in the Research Problem section above-improve students' writing skills in French as an L2. The improvement will be measured in percentages of less lexical/grammatical errors and awkward forms, of more natural sentences.

2. This study, albeit limited, suggests that the introduction of translation strategies into foreign language writing courses can have a positive effect on the naturalness of student writing output..

\section{Methodology}

There are three French Composition classes considered for this study: three sections of different cohorts. One from Fall 2014, which is the first control class; no translation task and no translation strategy were introduced in that class. One from Fall 2015, which is the second control class, in which one translation task and strategy were introduced. One from Spring 2016, which is the experimental class, in which translation strategies were introduced formally in class with a handout, and with translation tasks, after students wrote a first summary of the novel they had to read. They then wrote a second summary. To test the naturalness in students' writing and see if there was any noticeable improvement in the experimental class after the translation strategies have been introduced, all students' writing was error coded for wrong lexical/grammatical choice, deviant sentences, and natural sentences. Three repeated measures 
ANOVAs were run, one for each dependent variable (wrong lexical/grammatical choice, deviant sentences, and natural sentences), to see if participants improved throughout time, if there were differences between groups, and if there was an interaction effect between group and time; one-tailed post-hoc sample paired t-tests were then run to explore changes for wrong lexical/grammatical choice, grammatically and semantically deviant sentences, and natural sentences at the beginning and at the end of the semester for the two control classes, and before and after the translation interventions in the experimental class; those tests concentrated on each group, separately.

\section{Participants.}

There were eight participants in each class, and all were undergraduate students attending a French Composition class 33212/33214 at Kent State University. They had all been studying French for more than four semesters. The students were attending a French Composition class that was divided in two: French Composition, and French Composition Extended. Both classes were taught back to back, and they involved the same students, and the same material. Students read a novel—Pêcheur d'Islande (An Iceland Fisherman), by Pierre Loti (1886) — and they were taught how to reflect on the author's ideas, or writing, by expressing their views in compositions. In this class, students also wrote summaries, and they were graded according to a holistic grading scale (See Appendix I, and Appendix J).

\section{Method.}

Usually, in that French Composition course, during a fifteen-week Spring semester, students are taught French grammar (detailed review of grammar points seen in previous French classes), French culture, French vocabulary, and French syntax. In the experimental class (Spring 2016), some indirect translation strategies from English to French that could be useful to them 
while writing in their second language (French) have also been introduced in the middle of the semester. Translation strategies from Vinay and Derbelnet (1984), for instance transposition (shift in grammatical category), modulation (shift in point of view), equivalence (the same situation exists in both languages, but it is expressed with different phrases, such as idioms), amplification (the L2 will be using more signifiers than the L1, to cover gaps in syntax or vocabulary), and explicitation (information added in the $\mathrm{L} 2$ that is implicit in the $\mathrm{L} 1$ to enhance semantic clarity), are meant to help students understand the cultural intricacies of the French text (novel) they are reading for the class, and enlighten differences between the French and the English syntax. After a formal introduction to the strategies (also known as indirect translation processes, solutions, techniques, shifts, and "translation procedures" developed by Vinay and Darbelnet in 1958) (Pym, 2014) via a handout, students are asked to recognize translation strategies in the translation of an extract from the first chapter of the novel (French into English). They are also asked to think of them while they are producing sentences in French. They are asked to write summaries, and three compositions in French during the semester. This research focuses on how translation techniques impact the students' writing: did their syntax improve, does their writing sound more natural in French compared to non-translated French writing or writing performed by a French native speaker (Kobayashi and Rinnert, 1992), after they have been introduced to those techniques? Naturalness will be operationally defined for this study as well-formedness or rather well-formed sentences in text, as opposed to grammatical wellformedness (Sinclair, 1984).

According to Sinclair (1991), naturalness of a sentence can be determined thanks to the context in which the sentence is found. One must look at the whole text to determine naturalness as opposed to well-formedness at the sentence level, as a sentence can be grammatically well- 
formed, but still sound unnatural:

If we accept that the requirements of coherence and communicative effectiveness shape a text in many subtle ways, the term naturalness is simply a cover term for the constraints that determine the precise relationship of any fragment of text with the surrounding text. (p. 6)

Sinclair divides those constraints into three parameters at the sentence level: neutrality, isolation, idiomacity; each of which can be accounted for by three variables: supporters, rangefinders, and allowables. A neutral sentence can be one that has no support in the surrounding context. An isolated sentence has no rangefinders or allowables. A "rangefinder" is a related item in the cotext or context. "Allowables", which are pronouns in the sentence, depend on the context to be defined, but they do not interfere with the sentence's well-formedness. The naturalness of a sentence can be decided according to these variables, which make its presence acceptable or not among the text (Murphy, 2002). Two other authors are interested in naturalness in writing, and help define the term: Owen and McCarthy. For Owen, naturalness depends on what a native speaker finds acceptable or not. Naturalness is not a question of syntactic or semantic faultiness. McCarthy takes a corpus linguistics approach, and focuses on occurrences of verbs in the Birmingham corpus of English language, the Bank of English (BoE). His conclusion is that there are preferred ways of arranging words in languages (Murphy, 2002).

In this study, students' syntax and naturalness in writing will be evaluated via two types of errors, which, according to Kobayashi and Rinnert hinder message comprehension for a native speaker: lexical/grammatical choice (wrong word for the context, gender of articles, verb forms), and awkward form (phrases that are grammatically or semantically deviant) (Kobayashi and Rinnert, 1992). The two types of errors will be counted in the students' first and last 
compositions of the semester for the two control classes. They will also be counted in the summaries of the experimental class before, and after the translation strategies were formally introduced (March 11, 2016) and other interventions pertaining to translation were performed (February to April 2016).

The second method used follows McCarthy's collocation-based research. The use of the Canadian corpus Concordancier-corpus français that includes texts from the French newspaper Le Monde enables to look at which instances collocate with a certain verb for example. If at least one instance from the corpus collocates with the verb tested for example in the student's sentence, then the sentence is considered natural.

Ex: “...marier une femme” (marry a woman)

Figure 1. Screen shot showing collocations for the French verb "marier"

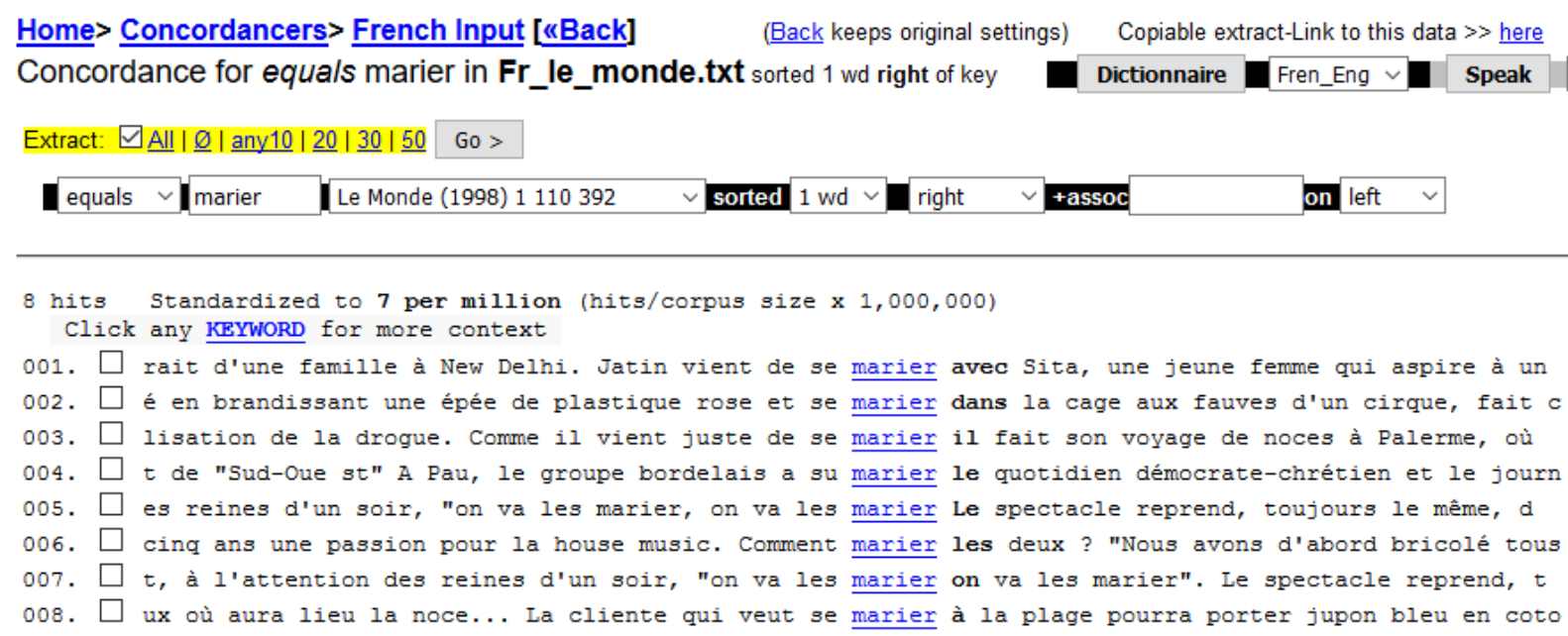

There are no instances in the corpus that correspond to the example given. The right expression in French is to use "with": se marier avec une femme, and the first instance displayed in the screen shot above shows such a usage. The third method follows Owen's method: a second reader and native speaker is asked to determine which sentences are natural.

In the experimental class, the second summary was written after formal translation 
strategies interventions that consist of the introduction of transposition in French and in English followed by exercises asking the students to use transposition in several sentences in relation to the novel they are reading (February 26-29). Other translation strategies such as modulation, transposition, explicitation were then introduced (Friday March 11). In a task in class, to be able to use those translation strategies, and understand them, students read a translation from an extract of the first chapter of the novel studied in class, and had to recognize translation strategies used by the translator (Monday March 14). As a second task, the same day, students wrote their own translation in English; they edited a translation from a peer, later in the semester (April 4); they back-translated from the translation of their peer (English back into French) to see how the communication went through or changed (April 6). This back-translation exercise-with an audience in mind - was beneficial in the sense that it opened discussions with the students that enabled them to become aware of their own language, and then realize the different processes used to reach different products. Reflecting on the L1 is a preliminary stage of awareness of how the L2 functions (linguistically, and culturally).

As an observation of those translation tasks in class, some of the students had strong reactions, and were even bewildered that the idea communicated had changed from the original text, depending on how their peers had translated the paragraph. As they were listening to their peers' feedback on their translations and back-translations, students understood the importance of being humble and accepting, but also that there are different ways to convey ideas to the target audience. There is no such idea as one and only one possible translation. Students realized how creative translation can be. They understood that sometimes even if the linguistic sign chosen is correct, the sentence can be unnatural. They realized that they have to step back from the sign, and look at the text as a whole. 
The breakdown of the coding and the data analysis is as follows:

1. Errors

\section{Coding}

For wrong lexical/grammatical choice: $<1>$ (wrong word for the context, gender of articles, verb forms)

For awkward form: $<2>$ (grammatically or semantically deviant sentences)

2. Naturalness

$>$ Coding

$<\mathrm{NG}>$ : Natural and grammatically correct

$<\mathrm{NG}>$ : Natural, grammatically incorrect

$<\mathrm{GN}>$ : Grammatically correct, but not natural

$<$ L1M $>$ : L1 Match: structural parallelism with the L1: unnatural but grammatically correct

Collocation search

Collocation search with the Canadian corpus Concordancier-corpus français

Statistical analysis

Three repeated measures ANOVAs were run, one for each dependent variable: wrong lexical/grammatical choice, deviant sentences, and natural sentences.

One-tailed post-hoc paired sample t-tests were run to track improvement in each group separately for each dependent variable.

The following tables represent a sample (with three students) of how the figures were obtained for the statistical analysis. 
CONTROL CLASSES (2014 and 2015)

Table 1 Analysis for natural sentences

\begin{tabular}{lll} 
& Control class (beginning) & Control class (end) \\
\hline Student 1 & $\begin{array}{l}\text { \# natural sentences } \div \text { Total \# } \\
\text { sentences in the text }\end{array}$ & $\begin{array}{l}\text { \# natural sentences } \div \text { Total \# } \\
\text { sentences in the text }\end{array}$ \\
\hline Student 2 & $\begin{array}{l}\text { \# natural sentences } \div \text { Total \# } \\
\text { sentences in the text }\end{array}$ & $\begin{array}{l}\text { \# natural sentences } \div \text { Total \# } \\
\text { sentences in the text }\end{array}$ \\
\hline Student 3 & \# natural sentences $\div$ Total \# & \# natural sentences $\div$ Total \# \\
& sentences in the text & \\
\hline
\end{tabular}

Table 2 Analysis for wrong lexica/grammatical choice

\begin{tabular}{lll} 
& Control class (beginning) & Control class (end) \\
\hline Student 1 & \# lexical/grammatical errors $\div$ & \# lexical/grammatical errors $\div$ \\
& Total \# words in the text & Total \# words in the text \\
\hline Student 2 & \# lexical/grammatical errors $\div$ & \# lexical/grammatical errors $\div$ \\
& Total \# words in the text & Total \# words in the text \\
\hline Student 3 & \# lexical/grammatical errors $\div$ & \# lexical/grammatical errors $\div$ \\
& Total \# words in the text & Total \# words in the text \\
\hline
\end{tabular}


Table 3 Analysis for Awkward Form

\begin{tabular}{lll} 
& Control class (beginning) & Control class (end) \\
\hline Student 1 & $\begin{array}{l}\text { \# deviant sentences } \div \text { Total \# } \\
\text { sentences in the text }\end{array}$ & $\begin{array}{l}\text { \# deviant sentences } \div \text { Total \# } \\
\text { sentences in the text }\end{array}$ \\
\hline Student 2 & $\begin{array}{l}\text { \# deviant sentences } \div \text { Total \# } \\
\text { sentences in the text }\end{array}$ & $\begin{array}{l}\text { \# deviant sentences } \div \text { Total \# } \\
\text { sentences in the text }\end{array}$ \\
\hline Student 3 & $\begin{array}{l}\text { \# deviant sentences } \div \text { Total \# } \\
\text { sentences in the text }\end{array}$ & $\begin{array}{l}\text { \# deviant sentences } \div \text { Total \# } \\
\text { sentences in the text }\end{array}$ \\
\hline
\end{tabular}

\section{EXPERIMENTAL CLASS}

Table 4 Analysis for Natural Sentences (2016)

\begin{tabular}{lll} 
& Pre-test & Post-test \\
\hline Student 1 & $\begin{array}{l}\text { \# natural sentences } \div \text { Total \# } \\
\text { sentences in the text }\end{array}$ & $\begin{array}{l}\text { \# natural sentences } \div \text { Total \# } \\
\text { sentences in the text }\end{array}$ \\
\hline Student 2 & $\begin{array}{l}\text { \# natural sentences } \div \text { Total \# } \\
\text { sentences in the text }\end{array}$ & $\begin{array}{l}\text { \# natural sentences } \div \text { Total \# } \\
\text { sentences in the text }\end{array}$ \\
\hline Student 3 & $\begin{array}{l}\text { \# natural sentences } \div \text { Total \# } \\
\text { sentences in the text }\end{array}$ & $\begin{array}{l}\text { \# natural sentences } \div \text { Total \# } \\
\text { sentences in the text }\end{array}$ \\
\end{tabular}

Table 5 Analysis for Wrong Lexical/Grammatical Choice (2016)

\begin{tabular}{lll} 
& Pre-test & Post-test \\
\hline Student 1 & \# lexical/grammatical errors $\div$ & \# lexical/grammatical errors $\div$ \\
& Total \# words in the text & Total \# words in the text \\
\hline Student 2 & \# lexical/grammatical errors $\div$ & \# lexical/grammatical errors $\div$ \\
& Total \# words in the text & Total \# words in the text \\
\hline Student 3 & \# lexical/grammatical errors $\div$ & \# lexical/grammatical errors $\div$ \\
& Total \# words in the text & Total \# words in the text \\
\hline
\end{tabular}


Table 6 Analysis for Awkward Form (2016)

\begin{tabular}{lll} 
& Pre-test & Post-test \\
\hline Student 1 & $\begin{array}{l}\text { \# deviant sentences } \div \text { Total \# } \\
\text { sentences in the text }\end{array}$ & $\begin{array}{l}\text { \# deviant sentences } \div \text { Total \# } \\
\text { sentences in the text }\end{array}$ \\
\hline Student 2 & $\begin{array}{l}\text { \# deviant sentences } \div \text { Total \# } \\
\text { sentences in the text }\end{array}$ & $\begin{array}{l}\text { \# deviant sentences } \div \text { Total \# } \\
\text { sentences in the text }\end{array}$ \\
\hline Student 3 & $\begin{array}{l}\text { \# deviant sentences } \div \text { Total \# } \\
\text { sentences in the text }\end{array}$ & $\begin{array}{l}\text { \# deviant sentences } \div \text { Total \# } \\
\text { sentences in the text }\end{array}$ \\
\hline
\end{tabular}

\section{Expected Results}

In the experimental class, the number of errors for lexical/grammatical choice and awkward forms are expected to decrease, and the number of natural sentences are expected to increase for the second summary, which would show that there was more cohesion in the students' texts after the translation strategies and tasks were introduced in class. Referring to Sinclair's theory of naturalness in text, a sentence is natural if its components have referents in the context. For example, a pronoun must have a referent in the previous sentence, otherwise it will not make sense. If lexical/grammatical choice errors, which correspond to: wrong word for the context, gender of articles, and verb forms, have decreased, it then means that students understood the right correspondences between pronouns and referents, for example, which reinforces the naturalness of the text.

It is expected that the results for the current study will show that translation strategies improve students' writing and made it more natural. Translation improves students' awareness of the language at the sentence and text level (vs. the sign). Translation strategies enable students to understand the functioning of the language beyond the lexical/grammatical level, or in other 
words to focus on the sentence and the text level.

\section{Limits}

The three classes were very heterogeneous. This could not be controlled; the students' background-if they spent some time abroad for example, if they already took an L1 writing class - did certainly determine their ability and openness to understand how translation strategies work.

In the experimental class, students were asked to self-reflect on their summaries, in a screen recording: they did this task for the first summary, and for the second summary. For the first summary or pre-test, students did not have any translation strategies in mind; they created a summary with the linguistic background they had at the beginning of the semester. They were then tasked with analyzing their writing in a reflection (self-reflection on their string of thought while they were writing the summary). For the second summary, this task came after the students studied the translation strategies in class; they wrote their summaries with the translation activities, as well as the audience, in mind. In a prompt, students were asked to address each of their sentences, and comment on their thinking process while they were building their sentences. It was expected that students understood, remembered, and applied what has been learned, and that should show in the reflection after the second summary. However, students were not used to this exercise, which did not yield results that are reliable. Additionally, this is a very demanding class; students are asked to read and to produce many essays and other assignments; follow-up interviews would have been too much for the students to handle given all the work they already produced. It was also noticed that students who were the least proficient in the language tended to be frustrated by translation until they became used to it. 
The novel used in class, assigned by the coordinator, is quite old (1886) with vocabulary that is sometimes obsolete, specific to the Brittany region of France, and written in a formal register. The students would thus have a hard time modeling this text, or in other words re-using its vocabulary and its syntax, even though reading in the target language always helps building their reading and their production competence in the target language.

\section{Conclusion}

Even if translation is still viewed by some as a tool that should be avoided in the language classroom, this study enables us to see how important it can be for students in a French composition class. Translation as perceived in Translation Studies—a communication toolcould be introduced at early stages of foreign language learning, so that students can get used to their role as communicators, and intercultural mediators. It will also help learners to perceive the second language as a whole, with its similarities and differences compared to their mother tongue. For example, using translation even in the elementary stages of second language learning enables the learners to look at the similarities first and then at the differences with their L1, and thus get a feeling of reassurance, as the new language is being linked to their familiar mother tongue (Nation, 2003).

\section{Further Thoughts}

This study should be furthered with even more students, perhaps at the graduate level, at which students are more mature, and more able to reflect on their own work. In his paper "Translator Training and Intercultural Competence", Katan mentions the different stages of students' maturity for cultural understanding, for example. The Developmental Model of 
Intercultural Competence (DMIS) shows how translators' beliefs about the task of translating for another culture changes over time (Katan, 2009). Cultural understanding and language learning go hand in hand, and translation can help develop this competence.

\section{Organization of the Dissertation}

This dissertation is written in five chapters. Chapter One introduces the study, and includes a summary of some background information, the research problem, the significance of the study, its conceptual framework, the research hypotheses, the methodology, the expected results, the limits, and further thoughts. Chapter Two offers a review of the literature regarding the history of Translation Studies and its relationship with second language acquisition. Chapter Three presents the methodology used to collect and analyze the data. Chapter Four describes the results obtained from the coding of sentences, the concordance search, and the statistical analyses. Chapter Five provides a conclusion to the study, with a discussion of the results, contributions of the study, its limits, and ideas for further research. 


\section{Chapter 2: Literature Review}

This chapter presents the literature linked to the history of Translation Studies (TS), and the relationship between that discipline and second language acquisition (SLA). The historical background is outlined, and different studies on the topic are discussed. As already mentioned in Chapter 1, translation in second language acquisition still divides scholars. Is translation beneficial for language learners, or does it hinder their learning?

\section{What is Translation?}

Defining translation and then Translation Studies is the first step to be able to comprehend why it has motivated our study. Translation can have different meanings in different contexts. Outside of Translation Studies, laymen would search for the term in the dictionary, and for example, give a definition as found in the Merriam Webster Dictionary: "a change to a different substance, form, or appearance" or "a rendering from one language into another; also: the product of such a rendering”. The Oxford English Dictionary is a little more precise; instead of using "a rendering" like the Webster, it uses the words "action" and "process": "The action or process of turning from one language into another; also, the product of this; a version in a different language", in rhetoric, "a transference of meaning, a metaphor". In the medical field and physics for example, it can refer to a "transference" of a disease or a form of energy. In creative writing, the writer translates words into thoughts (Perteghella, 2013). A "transference"

of meaning in rhetoric is considered an act of communication, and as George Steiner points out 
in his book, After Babel: Aspects of Language and Translation, "All acts of communication are acts of translation" (Steiner, 1975 p. 490). This means that verbal, visual or musical communication can be considered as acts of translation (Schulte, 2012). When we translate, we communicate a message from one language to another, and from one audience to another. Translation is intercultural communication. However, in Translation Studies, even though it is still difficult today to be satisfied with a definition of what translation really is (TirkkonenCondit, 2010, p. 220), some scholars argue that translation cannot be perceived as the "transfer" of a message because there is no pre-existing meaning. In other words, there is no such thing as the original, as a translation is a creation in itself. Different beliefs about this idea exist, depending on the translation domain. For instance, a localized product will be regarded by the audience as an entity in its own right, whereas in the scientific field, the reader may have to be referred to pre-existing text (Tirkonnen-Condit, 2010, p. 220). Translation Studies have been mentioned in this paragraph, and we will learn more about it in the following section.

\section{Translation Studies}

Translation Studies emerged and has been considered as a discipline since the late 1970s, when James Holmes coined the term. Despite its young age, the field gained more importance throughout time, and drew from many other disciplines like linguistics, comparative literature, semiotics, sociology, cognitive science, cultural studies. In that sense, it is interdisciplinary. Translation Studies expanded, and like every discipline that is growing, it saw many changes throughout time: the pragmatic turn of the 1970s paved the way for cultural studies in the 1980s, followed by corpus studies in the 1990s, and cognitive studies, which also started in the 1970s and developed in the 1980s and 1990s. There are three main trends in Translation Studies that 
are worth focusing on for the current study: cultural studies, corpus linguistics, and cognitive studies.

\section{Cultural studies.}

One of the major trends in Translation Studies comes from the merge between TS and cultural studies. This area of research in Translation Studies emerged from what was called the pragmatic turn in the 1970s that later became the 'cultural turn' in the 1980s (Snell-Hornby, 2006).

In the 1970s, the pragmatic turn of Translation Studies or textual turn, the name of which came from the introduction of text linguistics in translation studies, enabled new perspectives, especially towards practical and more flexible approaches to language and translation. The textual turn is of the essence for this study, as it separated Translation Studies from Linguistics and Comparative Literature while challenging the concept of equivalence. Linguistic translation theories were concentrating on details instead of texts as a whole, but literary Translation Studies became more interested in texts and the effect of the text on the reader. In 1964, Nida was already presenting his dynamic equivalence theory as opposed to the semantic equivalence: the purpose of dynamic equivalence was to achieve with the target text, an effect that was equivalent to the one of the source text (Vehmas, 2008).

Towards the 1980s, approaches began to change from prescriptive, source-text-oriented, linguistic views to more descriptive, target-oriented, functional views (Snell-Hornby, 2006). Actually, functionalist and communicative translation theories can be considered as the shift from the focus on linguistic aspects of translation to more communicative aspects. Texts were then considered as communication systems. In that sense, for example, the aim of Katharina 
Reiss and Hans Vermeer in the late 1970s, and then Even-Zohar in the 1980s, was to go from the linguistic phenomenon to translation as an act of communication.

Hans Vermeer's main idea is Skopos theory, from the Greek word "purpose”, which means that a translation has a goal (or a skopos). In other words, the translation has to be performed according to what is expected in the target culture. For Vermeer, culture plays a central role, and he thinks that the translator has to be bicultural (Snell-Hornby, 2006). Vermeer expanded on his theory, and in the 1980s, he concluded that there is no such thing as one and only one translation, i.e., meaning is altered while switching contexts: what is the most important is the skopos, and intratextual coherence (coherence of the target text in the target audience and coherence between the target and source text (Hatim, para. 6.3.3). The message needs to be conveyed for the translation to be understood by its reader (Vermeer, 1983) depending on the translation domain. Vermeer thus sees translation as a cultural transfer, rather than a linguistic transfer (Snell-Hornby, 2006).

As far as considering culture and the target culture in translation, (Toury, 1995) also argues that the recipient of the translation is the initiator of how translators are going to orient their translation strategies. Toury actually made that idea the motto of Descriptive Translation Studies (Snell-Hornby, 2006).

Another important scholar of the cultural turn in TS is Katharina Reiss. Her theory refers to a functional text-type approach, which finds its basis in the concept of equivalence, but is rather looking toward the communicative function of the text. As opposed to the theory of equivalence that considers sameness or equivalence between code-units between languages, Reiss' theory is focused on the text as a whole as a unit of translation. Another scholar, 
Christiane Nord (1997) also concentrates on texts and their function. For Nord, text analysis helps the translator understand the source text, and perceive the audience.

At the time, the fact that the focus was no longer on the source text, but rather on the target culture, was then helping to lead to other theories, like Even Zohar's polysystem theory, which concentrates on the relations between all the systems: translated literature operates as a system, which takes into account the way in which the target culture chooses works for translation, and the way translation norms are influenced by other systems (Munday, 2001). For example, in the literary system, which is part of other systems, Octavio Paz asserts that even if a text is unique, it is at the same time the translation of another text (1992, p. 154). Susan Bassnett and Andre Lefevere also played key roles during the cultural turn (Gentzler as cited in Snell-Hornby, 2006). Andre Lefevere is known for having examined the interaction between the concepts of power, ideology, and manipulation with respect to literary translation. His most important contribution is the ideological one: the translator's ideology or the ideology imposed upon him (Munday, 2001).

Other scholars also brought more ideas to the Translation Studies field, like Sherry Simon, who integrated gender and feminist studies into translation. Deconstruction, or the cannibalistic approach — the translation is freed from the original— was studied by Rosemary Arrojo (1986). Arrojo uses Derrida's deconstruction approach (1978), which states that a text is not fixed, that every reading gives a different translation. The translator becomes an author, and thus there is no such thing as the sacred original (Snell-Hornby, 2006). With deconstruction, any possibility must be taken into account: texts can be read according to what is present, but the reader also needs to think about what is absent. Meaning will depend on context, and context can change. As Jennifer Varney (2008) explains in her article "Deconstruction and Translation: 
Positions, Pertinence and the Empowerment of the Translator", "Language is therefore a signifying system in which signifiers refer to each other in an infinite circular process of meaning production" (p. 115). Deconstructing a text thus means to open the door to a plethora of meanings. While translating, translators are not bound to a fixed source, but rather need to take into account all the possible significations or interpretations of the text. This free play activity is often criticized in TS as an endless and futile activity (Koskinen, 2001, p. 240). At this point in time, Translation Studies is composed of several sub-fields, and a solution to bridge the gap between them could be to find a universal framework of TS (Snell-Hornby, 2006).

\section{Corpus linguistics.}

In the 1990s, a new approach to Translation Studies emerged with contributions from corpus linguistics. A corpus according to Baker (1995) is a collection of texts that are available in electronic form, and that can be analyzed automatically or semi-automatically. Corpus linguistics is an empirical approach to the description of language (Baker, 2001). In the 1980s, Holmes, and later Toury were not satisfied with the approaches that had been put forward so far. Evidently, Translation Studies was lacking a methodology, and none of the approaches could describe translations very well. Toury was especially dissatisfied with the limits of the tools in use for processing corpora at the time. Those tools did not give him the opportunity to have reliable statistical methods when dealing with translation norms (Baker, 2001). Toury was advocating for an apparatus that could allow the studies to be replicated. Later on, Baker became a very important scholar in the field of corpus studies, as she used the methods of corpus linguistics and implemented them in Descriptive Translation Studies (DTS). Baker describes different types of corpora like parallel corpora for instance, which are text in a language A with their translations in a language B. Parallel corpora can be used to show equivalence relationships 
between lexical items, for example (Marinai, Peters, \& Picchi, 1992). They can also give information about translation patterns dependent on a specific language pair (Baker, 2001). They can surely also be a good tool to show different translations for one given source text. Another example that can be given is Malmkjaer (1993). Malmkjaer argues that parallel corpora that have information about translators' backgrounds could give data that could be useful for psycholinguists who investigate the differences between first and second language acquisition (Baker, 2001). Sinclair (1991) is also worth mentioning in corpus studies, as he put forward issues in corpus studies like corpus composition, for example.

Other studies using corpus studies include Gellerstam (1986), who used a Swedish comparable corpus (texts in Swedish with texts from other languages translated into Swedish), which is the most useful type of corpus, according to Baker, for analyzing the specific features of translated texts, and for determining the frequency of certain vocabulary items that could lead to a greater standardization in translated texts than in original texts (Baker, 2001).

Corpus research in TS is not without issues though. It is difficult to determine what a translated text is: in the case of comparable corpora, nowadays with the Internet, it becomes hard to know which text is an 'original' and which text is a translation. It is also hard to get permissions from copyright holders for some projects. Malmkjaer (1998) emphasizes that attention should be paid to the selection of texts, and it would be useful also to have more context than the one given by the computer only. Kenny (1998) though, argues that research in TS can give new perspectives on corpora, thus making TS contribute to the field of corpus linguistics.

Nowadays, translators work with Computer Assisted Translation (CAT) tools and Translation Memories, which often come from corpora. Also, as (Zanettin, 2013) mentions, to be able to translate today, translators need to know how to manage corpora, and possess good 
analytical skills. Furthermore, TS researchers have to become familiar with other tools and methods to obtain and analyze data than only corpus analysis software (Zanettin, 2013).

\section{Cognitive studies.}

Looking into how the brains of translators work to determine how they translate is also another trend in Translation Studies. This approach is called process research, and is part of what was called the empirical turn in TS (in the 1990s). It came from the combination of cognitive sciences with translation research.

In the mid-seventies, process research was already underway, investigating interpreting processes with David Gerver $(1974,1976)$ and Barbara Moser (1978). In translation, process research came to life in the 1980s thanks to the work of Sandrock, then Gerloff, Krings and Lörscher (Shreve \& Angelone, 2010). Early process research has investigated translation competence for instance, and how it is linked to long-term memory. Also, it investigated translation units and translation strategies. Process research investigates the problems encountered in translation and their frequency, and the strategies employed by the translators to solve those problems (Krings, 1987).

To collect data in process research, think-aloud protocols (TAPs) were the first datacollection method used (Krings, 1986). However, because of issues encountered with TAPs, other methods like keystroke logging, eye tracking, screen recording have been developed, and are sometimes used together to be able to obtain more reliable data (Shreve \& Angelone, 2010). For example, Barbara Dragsted used keystroke logging and eye tracking to investigate how students and professionals coordinate source text comprehension and target language production processes (Shreve \& Angelone, 2010). Also, O’Brien (2006), and Alves et al. (Alves, Pagano, \& 
Silva, 2009) use eye tracking, key logging, retrospective protocols, and TAPs to obtain more reliable data (Shreve \& Angelone, 2010).

However, it remains difficult to access mental activities of the brain during translation. The findings of process research in TS are not conclusive or uniform, even though they suggest patterns in how translators translate, how they approach problems, and justify their translation choices (Bell, 2001). Also, it is difficult for translation researchers to give good operational definitions of categories such as experts, or professionals (Shreve \& Angelone, 2010). Today, process research is still looking for new methods to get more reliable data, as well as for ways to build new cognitive models, and more complete models of the translation process (Shreve \& Angelone, 2010). Process research borrows from other sub-disciplines of cognitive science like expertise studies, neuro-physiological studies, cognition and learning (Shreve \& Angelone, 2010). To a greater extent, process research in TS can also bring a greater understanding of human communication in general (Bell, 2001).

To summarize, TS has been developing and growing since the 1970s, with the contribution of sister disciplines, and numerous scholars. The methods and approaches borrowed from those neighboring disciplines helped develop different trends in Translation Studies, and expand the knowledge TS scholars can use for the study of translation. At this point, even if a great deal has already been achieved in translation research, and even if actually TS could even contribute to research in other fields like corpus studies, social sciences, and second language acquisition (in a mutual way), much more needs to be done to understand translation. The current study gives us the opportunity to explore that contribution made to second language writing while testing the usefulness of translation strategies in a French Composition class. 


\section{Translation Strategies}

As already mentioned, translation strategies exist under different names: procedures, techniques, or shifts, for example (Pym, 2014). The literature shows that it has been difficult to define translation strategies in Translation Studies, and some of the strategies have been criticized because they are considered too complicated or confusing (Jääskeläinen, 2010). Some of them are also specific to certain language pairs and are not universal (Pym, 2014). In his article "The Pedagogical Value of Translation Types" (2014), Antony Pym compares two types of translation strategies: those from Vinay and Darbelnet and those from Chinese scholar Loh Dian-yang. Pym discovered that students translating English-French preferred Vinay and Darbelnet's strategies, and the students translating Chinese-English preferred the Chinese scholar's strategies. He also concluded that those strategies need to be accompanied by practice for them to be fully understood, as declarative knowledge of strategies alone does not help students understand how those strategies are used.

In the literature, translation strategies have been divided in different categories by different scholars. As already mentioned, several terms have been used to describe the means used to translate: techniques, strategies, methods, procedures, tactics, rules, solutions, and plans. Scholars also decide on the level of intervention of the so-called methods or strategies used: they usually concentrate on the macro-level of the text to then focus on the micro-level. However, there is no unity in how the terms are used. They depend on the scholars' choices. For instance, there are textual and procedural strategies, which Dimitrova (2005) and Kearns (2008) distinguish as follows: textual strategies happen at the global level of the text, for instance domestication (adaptation of the translated text to the target audience) or foreignization (keeping elements of the source culture in the target text) (Venuti, 1998); procedural strategies refer to 
what happens during the translation process, and can be observed in translators' verbalizations (Jääskeläinen, 2010). For other scholars like Venuti (1998), there are more general strategies that are followed by more specific strategies: product-related strategies are related to the text, and they then call for methods of translating that text. Chesterman (1997) and Lörscher (1991) have similar views on the strategies. Chesterman presents three categories: syntactic, semantic, and pragmatic strategies. For Lörscher, there are general strategies that can be followed by other methods, which will be used to deal with the individual problem. For example, if foreignizing (keeping cultural aspects from the source text in the target text) is used as a global approach, then culture-bound items will be transferred to the target text. These can be called global and local strategies. Lörscher calls translation strategies "procedures for solving translation problems" (Lörscher 2002, p.101). He takes a psycholinguistic approach to the translation process. For him, strategies are goal-oriented, they are individual, and methods (direct transfer, calque, omission) are supra-individual. For instance, he distinguishes five types of goal-oriented individual problem-solving translation strategies that were used by the subjects of his study: Type 1: Realizing (that there is a translation problem), Preliminary solution Type 2: Realizing, Potential search for solution Type 3: Realizing, Verbalizing, Preliminary solution, achieve solution Type 4: Realizing, Potential search for solution, Verbalizing, Potential search for solution Type 5: Preliminary solution, achieve solution (2002, p. 104).

Jääskeläinen (2010) also suggests that translation strategies can be divided into global and local strategies, and she presents a map of the different strategies that can come into play while translating, which are displayed below (Fig. 1). She distinguishes also process-oriented (problem-solving) strategies and product-oriented (textual) strategies. She builds on Krings' 
view (1986) that strategies are plans representing mental action while solving a translation problem. Rules are socially prescriptive; tactics control an action, whereas strategies represent sequences of action (Jääskeläinen, 2010). According to Levý (1989):

Translating is a DECISION PROCESS: a series of a certain number of consecutive situations - moves, as in a game - situations imposing on the translator the necessity of choosing among a certain (and very often exactly definable) number of alternatives ( $\mathrm{p}$. $38)$.

Similarly to Lörscher, Hönig \& Kußmaul (1982) also favor a general approach strategy followed by decisions at the syntactic and lexical levels. Jääskeläinen (2010) proposes a translation strategies map showing global strategies and local strategies that can be implemented while translating (p. 384). Under the label "global strategies" or "macrostrategies", she presents process-oriented strategies (e.g. consistency) and product-oriented strategies (e.g. foreignizing, domesticating, summarizing). Then, under the label "local strategies" or "microstrategies", she presents the process-oriented local strategies on the one hand, such as problem-solving strategies, and on the other hand, the product-oriented strategies such as direct transfer, calque, paraphrase, and cultural adaptation. To give a concrete example of product oriented local strategy, one can refer to the example Chesterman (2000) gives in his article "Memetics and Translation Strategies". It is extracted from an article of the Guardian Weekly (March 23, 2000):

1. [The opening sentences] It is a corporate remake of The Empire Strikes Back. Two weeks ago a clutch of new technology stars soared into the elite of the FTSE 100 index. Since then, the shares of Freeserve, Psion and Kingston Communications have plummeted by more than a third, and even Baltimore Technology has lost more than $10 \%$ of its value. 
2. [Later in the article] But analysts warn that not all cheap stocks are bargains. Michael O’Sullivan of Warburg Dillon Reed points to companies with consistently good results and strong positions in their markets, such as GKN, the engineer, $\mathrm{CRH}$, and BAe. He likes technology stocks but says: "As for Freeserve and lastminute.com, we say waitaminute.com. (Memes in translation teaching section, para. 8).

How would we translate the play on words in the last sentence in another language? Would we decide to choose a local equivalent (cultural adaptation - pragmatic strategy) or perhaps should we keep the original and provide some explanation?

In defining strategies, some scholars have focused on culture. For instance, Hervey and Higgins (1992) present a compensational model of strategies. Given the incommensurability between some elements in two different cultures, Harvey and Higgins propose compensation strategies for any loss. A cultural transposition occurs every time there is a cultural problem to deal with: exoticism and cultural transplantation, cultural borrowing, calque, and communicative translation help bridge any cultural gap (Piotrovwska, 1998). Piotrovwska (1998) distinguishes between strategies and techniques. She calls strategies "context-oriented procedures" (p. 210); translators consider the target text (TT) audience, the purpose and nature of the source text (ST); those procedures are text-oriented. Techniques are specific ways of acting as mental processes for a translator when he or she is faced with a translation problem. They are made for accomplishing tasks; they are problem-oriented (rephrasing, omission, addition, substitution, etc.). Strategies and techniques are both related, and strategies come before techniques in hierarchal order. It is difficult to define translation strategies, and also, as Pym asserted, his study showed that pedagogically speaking, translation strategies only have a beneficial impact if taught accompanied by practice (Pym, 2014). 
In the present study, as participants are in a French Composition class, and are introduced to translation strategies, the ones used are Vinay and Darbelnet's (see Table 7), who call these strategies "procedures" in their book Comparative Stylistics of French and English (1995), as well as Skopos theroy. Vinay and Darbelnet's procedures help learners to understand the differences in syntax in English and French, as they offer solutions where a direct equivalent is not possible. Skopos theory can be considered as a global strategy, and Vinay and Darbelnet's strategies can be considered as local textual strategies. 
Table 7 Adapted from Vinay and Darbelnet's Main Translation Procedures Listed in Increasing Order of Difficulty (1995, p. 41) https://benjamins.com/catalog/btl.11

\begin{tabular}{|c|c|c|c|}
\hline Procedure & English & French & Comments \\
\hline 1. Borrowing & $\begin{array}{l}\text { John bought a } \\
\text { croissant yesterday } \\
\text { at the supermarket. }\end{array}$ & $\begin{array}{l}\text { John a acheté un } \\
\text { croissant au } \\
\text { supermaché hier. }\end{array}$ & $\begin{array}{c}\text { The word "croissant" } \\
\text { is borowed from } \\
\text { French. }\end{array}$ \\
\hline 2. Calque & $\begin{array}{l}\text { They went to Hawaii } \\
\text { for their honeymoon. }\end{array}$ & $\begin{array}{c}\text { Ils sont allés à Hawaï } \\
\text { pour leur lune de } \\
\text { miel. }\end{array}$ & $\begin{array}{l}\text { "honeymoon" is } \\
\text { literally translated in } \\
\text { French. }\end{array}$ \\
\hline $\begin{array}{l}\text { 3. Literal } \\
\text { translation }\end{array}$ & What time is it? & Quelle heure est-il? & \\
\hline 4. Transposition & $\begin{array}{l}\text { They had a lot of fun } \\
\text { at Jacques' party. }\end{array}$ & $\begin{array}{c}\text { Ils se sont beaucoup } \\
\text { amusés à la fête de } \\
\text { Jacques. }\end{array}$ & Noun/verb. \\
\hline 5. Modulation & Perhaps you are right. & $\begin{array}{c}\text { Tu n'as peut-être pas } \\
\text { tort. }\end{array}$ & $\begin{array}{l}\text { The point of view is } \\
\text { shifted here. }\end{array}$ \\
\hline 6. Equivalence & $\begin{array}{l}\text { Once bitten, twice } \\
\text { shy. }\end{array}$ & $\begin{array}{l}\text { Chat échaudé craint } \\
\text { l'eau froide. }\end{array}$ & $\begin{array}{l}\text { Some idioms have } \\
\text { equivalents. }\end{array}$ \\
\hline 7. Adaptation & Cock-a-doodle-do & Cocorico & Onomatopoeias. \\
\hline
\end{tabular}

The table below will help visualize what has been presented in this section.

Table 8 Summary of Translation Strategies

Author Title of the strategies

Action

\begin{tabular}{lll}
\hline $\begin{array}{l}\text { Dimitrova (2005) Kearns } \\
\text { (2008) }\end{array}$ & $\begin{array}{l}\text { Textual strategies. } \\
\text { Procedural strategies. }\end{array}$ & $\begin{array}{l}\text { Outside the text. } \\
\text { What happens during } \\
\text { translation process. }\end{array}$ \\
\hline Venuti (1998) & $\begin{array}{l}\text { Product-related strategies. } \\
\text { Methods for translating text. }\end{array}$ & $\begin{array}{l}\text { General } \\
\text { Specific }\end{array}$ \\
\hline Chesterman (1997) and & $\begin{array}{l}\text { Syntactic, semantic, } \\
\text { pragmatic. }\end{array}$ & \\
Lörscher (1991) & $\begin{array}{l}\text { General strategies followed } \\
\text { by other methods. } \\
\text { Conscious procedure. }\end{array}$ & $\begin{array}{l}\text { Foreignizing } \rightarrow \text { culture- } \\
\text { bound items used. } \\
\text { Goal oriented. Individual, and } \\
\text { supra-individual. }\end{array}$
\end{tabular}




\begin{tabular}{|c|c|c|}
\hline \multirow[t]{2}{*}{ Jääskeläinen (2010) } & \multicolumn{2}{|l|}{ Global and local strategies } \\
\hline & $\begin{array}{l}\text { Rules } \\
\text { Tactics } \\
\text { strategies } \\
\end{array}$ & $\begin{array}{l}\text { Socially prescriptive. } \\
\text { Control an action. } \\
\text { Sequences of action. }\end{array}$ \\
\hline Krings (1986) & $\begin{array}{l}\text { Translation strategies }=\text { plan } \\
\text { to solve translation } \\
\text { problems. }\end{array}$ & \\
\hline Hönig \& Kußmaul (1982) & $\begin{array}{l}\text { General approach strategies } \\
\text { followed by decisions at the } \\
\text { syntactic and lexical levels. }\end{array}$ & \\
\hline \multirow[t]{2}{*}{ Piotrovwska (1998) } & Strategies & $\begin{array}{l}\text { Context-oriented procedures } \\
\text { (or text-oriented). }\end{array}$ \\
\hline & Techniques & $\begin{array}{l}\text { Specific ways of acting as } \\
\text { mental process (problem } \\
\text { oriented). }\end{array}$ \\
\hline \multirow[t]{2}{*}{ Vinay and Darbelnet (1995) } & $\begin{array}{l}\text { Translation procedures or } \\
\text { methods }\end{array}$ & $\begin{array}{l}\text { Looking for a solution to a } \\
\text { translation problem. }\end{array}$ \\
\hline & & $\begin{array}{l}\text { Must be supplemented by } \\
\text { documentation on the social } \\
\text { environment of the text. }\end{array}$ \\
\hline
\end{tabular}

\section{Translation and Second Language Acquisition}

Translation and SLA have a long history of controversy (Carreres, 2006, pp. 1-2). In ancient times, when the Roman Empire was expanding, so did Latin. Translation was used to translate Greek works, and it was perceived as a privilege to be able to translate into Latin. Translation was also used for the teaching of Latin and Greek, to learn grammatical forms, and to improve rhetorical proficiency, for which it was not only perceived as an exercise, but also an art form (Copeland, 1991). The Romans were in fact the first ones to consider translation part of writing instruction. They would ask their students to imitate (referred to as Imitatio or Mimesis) and paraphrase texts of previous works to improve their rhetoric. It is worth mentioning that for Cicero (106-43 BC) — Roman philosopher and orator — translation should not be performed word for word. Quintilian (35-100 AD) — Roman rhetorician— advocated for Imitatio to enhance 
compositions. The teaching of Latin continued until the seventeenth century, and Latin then evolved little by little into other languages. It was still taught, but remained a dead language the purpose of which was to master grammatical structures rather than to use as a communication tool. When other foreign language courses started in Europe in the eighteenth century, the tradition of using grammar as a learning tool continued, which gave birth to the grammartranslation method (GTM).

\section{The grammar-translation method.}

The GTM is the method that ended the use of translation in the foreign language classroom, and following are the reasons behind this dismissal. As Latin decreased as a spoken language in the sixteenth century and became a means to master grammar and rhetoric, its model of teaching was used to teach modern languages until the nineteenth century. Latin was taught to develop intellectual skills and was the basis of higher education in Europe. Modern languages textbooks mimicked the teaching of Latin with grammar rules, lists of vocabulary, and sentences meant to be translated. The learning experience was set around grammar. This method became the grammar-translation method, which was first known in the United States as the Prussian Method in the nineteenth century (Richards \& Rodgers, 2014, p. 6).

At the time, people were traveling much less, and foreign languages instruction was made available to make foreign literature more accessible. The emphasis was on reading and writing, and not so much on speaking. Vocabulary was learned as lists, and not in context. The focus was at the sentence level and on translation of these sentences, as well as on accuracy. Students learned grammar rules, and then practiced this grammar while translating. Also, the L1 was mostly used in the classroom (Richards \& Rogers, 2014). The GTM was used until the 1940s, and was gradually replaced with other methods. 


\section{Ban of grammar-translation method and rise of the communicative method.}

The grammar-translation method, or indirect method, was rejected because it did not focus on orality. It was also depicted as authoritarian and unintelligent (Kupske, 2015, p. 55). That method started to be questioned by the reform movement, which focused on three principal ideas: speech is a priority learning goal, texts used in class must be interconnected, and the classroom methodology must be based on orality (Randaccio, 2012, p. 10). The members of the reform movement concentrated on language learning in a natural way, as seen in the acquisition of the mother tongue, mimicking the way children learn a language (Richards \& Rogers, 2001, p. 11).

The University of Nice Sofia-Antipolis' website in France has a web page dedicated to grammar-translation, and there are three citations on that page that illustrate quite well the status of the grammar-translation method even today: all three of them condemn it. The first citation is from the British Council:

A way of teaching in which students study grammar and translate words into their own language. They do not practise communication and there is little focus on speaking. A teacher presents a grammar rule and vocabulary lists and then students translate a written text from their own language into the second language. See communicative approach (Université Nice, n.d.).

The second one is from the Bogglesworld ESL glossary:

A dull, dry, and ineffective teaching method completely devoid of theoretical justification. The method has its roots in the teaching of Latin. The method focuses on translating grammatical forms, memorizing vocabulary, learning rules, and studying conjugations. Its focus is on accuracy and not fluency. Emphasis is on form and not on 
meaning. Paragraphs are dissected for form, while students and teacher could care less if the paragraph actually has anything worth saying. Another problem with this method is that most of the teaching is done through explanation in the learner's first language (Bogglesworld, n.d.).

And the third one from Scott Thornbury, an English language teacher from Spain:

Grammar-Translation (GT) has come to be seen as the antithesis of good teaching practice, and much scorn is customarily heaped upon it. This bad reputation is not entirely undeserved: GT is associated with a very grammar driven approach to learning, with an emphasis on accuracy rather than fluency, and on the written form rather than the spoken form. Moreover, most exercise types in traditional GT courses work at the sentence level or below: there is no such thing as authentic text, for example, in a standard GT course. In fact, inauthenticity is a hallmark of GT courses, and lends itself to endless ridicule (Thornbury, 2010).

In the 1980s, methodologists were advocating the exclusive use of the L2, and the GTM was used as the proof that the L1 should not be used in language teaching (Cook, G., 2010). For some scholars like Lado (1964), translation could not be used in place of language practice, and thus should not be used at all. It was considered as being too complicated and too different from the four main language skills.

After the GTM, the direct method then came to life, ordered by the reform movement. It consisted of dialogues from everyday life. The focus was on induction: from example to the rule, and meaning was given via demonstration and action (Richards \& Rodgers, 2001, p. 09) The L2 had to be used exclusively, with a focus on speaking and pronunciation, so that the foreign language could become a habitual and natural way of communication (Leffa, 2012). 
Following the direct method was the Audio-lingual method, which, similarly, consisted of speaking rather than writing but rather than repeating vocabulary, learners had to repeat grammar drills, and classes were taught in the L2 (Carreres, 2006). With all these new methods, the L1 was perceived as a completely bad influence in the foreign language classroom, and that became a popular belief that is sometimes still maintained today (Kupske, 2015).

Methods like the communicative approach at the end of the 1970s, which concentrates on learners' ability to learn the L2 in context, and in the classroom — everyday activities are reproduced in the classroom, or task-based learning for example — totally avoid the L1. The L1 will only be mentioned in the discussions of advice as to how one can avoid its use (Cook, 2001). The use of the L1 in these contexts would be counterproductive, and thus is not justified. In the same view, listening, as well as reading, were secondary skills (Nunan, 1999). Reading was not considered as a "communicative" activity (Kupske, 2015, p. 57), which is another argument for avoiding translation (as translation implies the reading of a text). For example, below are Newson's (1998) arguments about translation being a disadvantage in the foreign language classroom; translation:

i. encourages thinking in one language and transference into another, with accompanying interference;

ii. is independent of the four skills which define language competence: reading, writing, speaking, listening;

iii. deprives teacher and learner of the opportunity to benefit from accruing advantages of working within one language; iv. it gives false credence to the naïve view that there is such a thing as simple word-toword equivalence between languages; 
v. does not allow or facilitate the achievement of such generally accepted L2 teaching objectives as:

- emphasis on fluency in spoken language,

- attention on the controlled introduction of selected and graded structures (1960s style) or communicative competence strategies (1990s style),

- attention to controlled introduction of and mastery of selected and graded lexical items,

- the use of situationalized, contextualized language,

- communicative language use,

- learner-centred language learning,

- absence of observable learning effect, either of new vocabulary or structural items. (pp.

63-64)

In light of these examples, the GTM was perceived as inauthentic, static, noncommunicative. While there seems to be only negative arguments about this method, even today, this approach, mixed with others, could be used in foreign language teaching. Chang (2011), for example, with his study of a comparison of the translation-grammar method and the communicative method in a foreign language class concludes that the GTM can still be used in combination with the communicative method to teach English grammar, for instance. Moreover, it seems the GTM was not as terrible as one might think. The idea that the method was not efficient was reinforced by those who thought that the study of foreign languages such as French or German had to be as rigorous as learning classical languages (Richards \& Rodgers, 2001).

Other methods like the communication approach and other methods banning the L1 in the foreign language classroom makes it practically impossible for translation to have a place in those courses. However, it is almost impossible to completely ban the L1 from a language 
course. Even though some might think that immersion is the ultimate way of learning a foreign language, the simple example of students working together in an elementary foreign language class to be able to talk to each other and exchange ideas, shows that the L1 is not a means that should be dreaded by teachers (Cook, V. 2001). Furthermore, studies like Alegría; De la Colina and García Mayo’s (2009), in which undergraduate foreign language learners were observed during collaborative tasks, revealed that students used the L1 for metacognitive talk and metatalk. It enabled them to handle tasks more efficiently (p. 343). The use of the L1 is also discussed in immersion programs, both in French and Spanish (Bao, 2015, p. 14). For example, Swain and Lapkin (2000), who looked at French immersion students working in pairs while using the L1, determined three different uses of that language (p. 257-258):

- Making sure the instructions are understood, and deciding about the role of each collaborator

- Discussing the vocabulary encountered

- Building a relationship between students

The researchers also reveal that while talking to the immersion program teachers, those confided that they do not like using group work because students use the L1 during that time, which is very difficult to control and prevent (Swain \& Lapkin, 2000, p. 258).

\section{The positive use of the $L 1$ in the foreign language classroom.}

The focus of the recent methods mentioned above was on the use of the L2 mainly. Students are expected to think in that language (Kupske, 2015, p. 56). However, some scholars maintain that the L1 has a place in the foreign language classroom, and that is of importance for our study, as the use of translation in the foreign language classroom includes both languages, the L1 and the L2. For example, in Pablo's 2011 study, it is concluded that the use of the L1 is 
beneficial in the language classroom, but the decision to use it or not is made according to individual beliefs (p. 124). Also, as mentioned earlier, students use the L1 in the classroom to work together (Kupske, 2015). If the L1 is present when students work in groups, that means there is informal translation taking place, and it might help improve students' vocabulary for example, and help them learn from each other (Atkinson, 1987). For V. Cook (2001), the L1 can be pictured as a cornucopia, as there are many different ways to use it. It is used not only by students during their collaborative work, but also by teachers to explain concepts, grammar points, and also for matters of organization. For him, the L1 should not be avoided at all costs; evidently, how can one language be completely banned or compartmentalized in the brain? Cook writes about the L1 and the L2 being linked, which reflects the idea of compound bilingualism: there are no distinct compartments in the brain in which to put the $\mathrm{L} 1$ on one side and the $\mathrm{L} 2$ on the other, as languages are interconnected. Grosjean and Soares (1986) also argue that even if one of the languages is prominent in a situation, a complete deactivation of the other language in the brain never happens (Duran, 1994).

V. Cook (1991) mentions code-switching, which is a bilingual activity in which the speaker switches from one language to the other in the same sentence, and is widely used in foreign language situations outside of the classroom. Even if code-switching is still perceived as unconventional by some - a recent study (2014) by Olmo-Castillo showed that teachers still have some misconceptions about code-switching (p. 6) - it could present an opening to understanding how bilingualism works, and could advocate for the use of the L1 in the language classroom. Code-switching is a natural feature, and there is no reason why students should not use it. Brown (2001) argues that scholars now should have acquired enough experience to see that complete immersion is not natural, as the L1 exists in the brain and is always present even for fluent 
bilinguals, and to thus understand that the L1 has a place in the foreign language classroom. Many scholars attempted to define code-switching and also code mixing, but the distinction between both is often not made and code-switching is used as an umbrella term for both (Mabule, 2015). Code-switching can happen in speech, but also in writing. For example, as Bandia (1996) explains in the case of African writers, following Gumperz's definition of codeswitching: "the juxtaposition within the same speech exchange of passages of speech belonging to two different grammatical systems or subsystems" (Gumperz, 1982, p. 111). Another scholar, Singh (1985), also cited by Bandia, uses the term code-mixing for intersentential switching (Bandia, 1996, p. 140). In addition, Mabule (2015) defines code mixing as "expressions in which a mixture of the grammar of one language and another language is used without altering the grammar of the first language used" (p. 341). In view of these definitions, in our study, it is the term code-switching that attracts our attention, as students often use the L1 and the L2 grammar and/or syntax mixed in their writing.

\section{The Return of Translation in the Foreign Language Classroom (Pedagogical Translation)}

The communicative approach has been undergoing some changes recently in the language learning classroom (Kupske, 2015). It seems that the problem in the GTM was not translation per se, but rather the fact that this method was lacking a communicative component (Kupske, 2015). For some scholars who studied the question such as Omura, (1996), Shiyab and Abdullateef (2001, pp. 1-2, and 7), translation can have a positive and facilitative role, as students learn consciously and explicitly, which should reduce language interference. In addition, students become active participants, which helps achieve meaningful learning (Kupske, 2015). Translation also brings motivation (Mogahed, 2011, para. 18). 
Some studies concentrated on the opinion of learners and teachers about the use of translation in the foreign language classroom. For example, Carreres $(2006$, p. 8) concluded that students think translation is helpful for L2 learning. He also advocates for the use of translation trainer methodologies (p. 18). For Conacher (1996), Lavault (1985), or Hervey et al. (2005, p. 5), students enjoy doing translation activities and ask for them. In the same way, Felipe Flores Kupske (2015) asserts that if translation is not limited to grammar exercises, and is well incorporated in the classroom by professionals, it can be a very useful tool (p. 62). Kupske is not the only one suggesting well-planned translation activities: Phillip Kerr (Macmillan Education ELT, 2012) also gives many examples of translation activities in his webinars. He insists on students collaborating in the classroom. However, in the examples given, Kerr waits for his students' translations and then gives them a single model translation, which he presents as definitive, but there is no such thing as one and only one translation, as it is impossible to read the source text the same way multiple times even for the same translator over time. His mention of the usage of glossaries instead of dictionaries can be a good idea. However, online dictionaries are available, and it is difficult to forbid students to use them. Translators for example need to check their terms constantly, and will use dictionaries or parallel documents. Outside of the classroom, learners of a foreign language will not always have the opportunity to use glossaries, as those are not always provided and will be forced to use a dictionary, so it might be a good idea to teach them how to use one properly_especially also monolingual dictionaries, which help check meaning in context. Kerr also uses examples with errors and bad translations, to show how word for word translation produces a nonsensical target text, for example on a menu in a restaurant. 
If students are fluent enough in the foreign language, this method of showing errors to students might work. However, if they are not fluent enough, showing them errors might have the opposite effect, as noticed in a French Composition class at Kent State University in 2014: they will keep the error in mind and reproduce it instead of being able to correct it. In his webinar, Kerr mentions the use of Google Translate ${ }^{\mathrm{TM}}$ and how it can help students realize that using translation software is not how a native speaker would write or say a specific sentence or expression (Macmillan Education, 2012). How would students make the sentence sound more natural, then? Are any improvements proposed? Kerr does not say. However, while it is true that students can be shown the limitations of Google Translate ${ }^{\mathrm{TM}}$, which is a positive point, they need to be redirected towards a dictionary that displays examples, as well as parallel texts and parallel corpora, as context is important. Or, their attention should be drawn to Google Translate ${ }^{\mathrm{TM}}$ 's new feature that shows sentences in context. In any case, students should be made aware of other tools to help them achieve their goals.

Many studies conducted with translation in the L2 classroom pertain to Eastern European or Indo-Asian locations to teach English as a second language (Elmayantie, 2015). Perhaps this regional scope is due the fact that one of the misconceptions about the use of translation in the foreign language classroom is the belief that in classes taught by native speakers of the $\mathrm{L} 2$, the L2 should be favored (Leonardi, 2010). Chang (2011) in his study of a comparison of the translation-grammar method and the communicative method, concludes that both methods combined yield great results in grammar teaching of English. He argues that both respectively bring accuracy and fluency, which are the goal of English learning. Another scholar, Leonardi (2010), advocates for the use of pedagogical translation in SLA, and distinguishes pedagogical translation from translation pedagogy: pedagogical translation is used as a teaching tool in the 
foreign language classroom, and translation pedagogy is used to train translation professionals (p. 81) She maintains also that pedagogical translation, used properly, can be a communicative activity, not only concentrating on accuracy. Leonardi also mentions some pedagogical translation activities, such as a summary translation, and literal translation. Duff also mentions that translation activities can be used to improve the four skills and "develop accuracy, clarity and flexibility" (Duff, 1989, p. 7). However, those activities must be well designed. According to Hurtado Albir (1999), there are common mistakes made by L2 teachers that can hinder the efficacy of those activities. One of the mistakes is to choose the texts for translation randomly. The second mistake would be not to give students instructions for the translation. Finally, excluding translation theory that goes hand in hand with practice is another pitfall (Albir, as cited in Carreres, 2006, pp. 15-16).

\section{Scholars who are against, and scholars who are for, the use of translation.}

Regarding the way translation can be used in the classroom, Malmkjaer (1998) argues that if translation is taught the same way it is in professional translation, it can activate the four language skills and bring great advantages in L2 learning (pp. 8-9). Kupske (2015) would like to promote the use of translation in the foreign language classroom, and provide L2 teachers with resources on translation theory and try to take them onboard to be able to fight against the taboo idea that translation should not be used in the foreign language classroom. Indeed, many scholars defend the use of translation in the foreign language classroom. For Owen (2003), translation should be used to fine-tune the target language. It is a good way to integrate explicit language teaching in the foreign language classroom. In the same way, thanks to her study of students' beliefs about using translation to learn the English language, Liao (2006) draws positive conclusions about the use of translation in foreign language teaching: 
- it may help students to better understand the L2;

- it may help students to evaluate their comprehension;

- it eases memory impediments in learning new items, idioms, syntax and grammar;

- it may help students to develop and express ideas in the L2;

- it can reduce learning anxiety and boost motivation to learn the L2 (p. 201)

In her study of 2010, Rocha concentrated on having students translate descriptions of art, as the purpose of her class was for the learners to acquire information organization skills in L2 descriptive text writing. Even though the translation tasks used were not varied, and remained quite mechanical while mimicking L2 descriptive texts, she concludes that her method proved to be efficient (p. 53).

Translation can also be used at any level of learning as it can help improve the four language skills (Leonardi, 2011). This idea should be dealt with caution, though, as translation at an early stage of foreign language acquisition should not fall into the 'dry drills' category, but rather stay a means of communication. Indeed, Leonardi, in the same way as Christina Schäffner (1998), distinguishes pedagogical translation from translation pedagogy: pedagogical translation's purpose is the reproduction of meaning for language learning purposes with an emphasis on grammar forms, whereas translation pedagogy is used in translator training and it represents the production of text for a specific purpose. That distinction, even though it seems to push TS and SLA apart, should in fact help bring the two disciplines together, as there is always an advantage in learning from different methods.

In addition, even though the use of translation in the foreign language classroom has some advocates, some scholars think that translation should not be present. For example, Kobayashi and Rinnert (1992) in their study, conclude that translation can hinder students' L2 
writing. Older studies suggest that translation should not be used in the L2 classroom, as it is too different from the four language skills: reading, writing, speaking and listening, and it cannot replace language practice (Gatenby, 1967). More recently, Newson (1998) put forward disadvantages of the use of translation as a teaching and a testing tool in an English as a Foreign Language situation. He states for instance, that translation prevents the learner and the teacher from working in one language exclusively; it makes learners believe that there is word-to-word equivalence between languages; it hinders some goals of language teaching such as fluency in speech, the use of language in context, the use of communicative language, and learner-centered learning.

The current study proposes to test whether the introduction of translation strategies affects L2 writing, and if so, how. In that sense, it is important to explore what has been written about L2 writing and see how it is usually approached and the methods that are used to improve it.

\section{Research in L2 Writing}

Research in L2 writing includes ways to improve students' skills, different kinds of assessment, and cognitive processes used during the writing activity. Students' L2 writing can be enhanced with different teaching techniques (Ishikawa 1995) such as writing out picture stories, or supplemental grammar work (Frantzen, 1995).

Different measures for assessing linguistic accuracy can be used in compositions: holistic scales, number of error-free units, and number of errors (with or without error classification) (Polio, 1997); 4-component scale from Tarone et al. (1993), Kroll's error classification system 
(1990) (Polio, 1997). Most studies use Think Aloud protocols, even though this method is now thought to hinder the performance of the subjects (Bowles, 2010, p. 14).

In psychology, some learning mechanisms have been identified as explanation for the improvement of fluency in foreign language learning. For example, automated processing is referred to as fast and efficient, and it happens in well-practiced tasks. Controlled processing is slow, effortful, and inefficient in new tasks. McLaughlin et al made the connection between fluency (the rate at which a speaker utters sentences in a given language) and automated processes, stating that one of the differences between a fluent and non-fluent speaker is the level of automatization used to process vocabulary, and thus experts exhibit more automacity than novices (McLaughlin et al, 1983, p. 148). In that sense, if students acquire automated processes, they may be more fluent, and they also may enhance their naturalness in writing of the L2. A similar situation can be noticed for novices and experts in translation: experts in translation solve translation problems automatically (Jääskeläinen, 2010, p. 220).

Those cognitive processes can be found and displayed in different models of writing. There is Kellogg's model of cognitive processes in writing (1999) (Hayes, 2006), Hayes' framework of cognitive processes in writing (Hayes, 2006), and Levelt's model of first language speaking. Kellogg's model presents planning and translating (from thoughts to writing), programming and executing, reading and editing. For him, some writing processes rely on the working memory, but some others do not. Translating and reading use the verbal working memory; editing and planning use the spatial working memory, and programming and executing motor movements use neither-The executive function manages the verbal and visual information (for planning, translating, programming, and reading).

In Levelt's model, lower processing is more automatized than high level processing (De 
Bot, 1992). His model follows Kellogg's in the sense that he presents planning as corresponding to conceptualization, translating representing formulation, and execution representing articulation. However, Levelt's model is for speaking. Kellogg's is for writing and can probably raise some differences with L2 writing, as L2 writers use their L1. Zimmerman (2000, pp. 85-87) and Raab (1992) concluded that L2 writers were not using their L1 at the translation stage (transform thoughts into written words), but were rather using it in global planning. And even though some studies mention the use of the L1 at the planning stage only, some other studies such as G. Cook's (2007) reveal that students translate mentally when they write, so they use their L1 also at the production stage.

For Hayes, writing processes all draw from the working memory (Hayes, 2006). Kellogg's model has been tested by Hayes and Chenoweth, and Levy and Marek (1999). Levy and Marek's studies confirmed Kellogg's hypotheses that text production and editing do not include the phonological component. Hayes and Chenoweth's was mixed. Some scholars also do not support the idea of a drafting stage, as some writers can start writing, and the ideas come along as they write (Elbow, 1973). For Elbow, this technique serves to free the writers as they can write more openly as they go, without constantly editing. Kellogg stated that this method can be beneficial for certain types of writers and certain kinds of texts, especially literary texts (Hayes, 2006).

There is also activity theory that can be applied to writing. Activity theory consists of describing actions that have a goal and are related to the environment in which the person performs the action. In other words, students' writing can be influenced by the environment they are in when they write. The "activity" represents the action and its environment. Russel and Yanez (2003) did a study that produced a model of an activity system, 
which can help understand some issues detected in students' writing. These scholars looked for differences in the activity system, as the participants were experiencing conflicts. In their specific case, what was causing issues for the students of an Irish History course, were norms and goals of writing. These were not specified enough, which led students to write in a different way than what the teacher expected. The students had their own norms, and would write while being influenced by their educational background. For example, one of the participants was a journalism major, and would write short factual paragraphs, which were not appreciated by the teacher, who was basing her grading on academic history norms and was expecting long paragraphs including critical analysis (Hayes, 2006, p. 38).

Those models can perhaps help to understand naturalness in writing. The literature is full of studies about fluency in speech, but is lacking studies about naturalness in L2 writing. For example, Alex Gilmore used online corpora to test the improvement of naturalness in students' L2 writing. The conclusion was that after only a ninety-minute session, students were able to improve their naturalness in writing while correcting their own errors using online corpora (Gilmore, 2009, p. 369).

The textual turn in Translation Studies, as well as the relationship between translation and second language acquisition enable one to understand why the current study can be of importance. The research mentioned above is used in the current study, the methodology of which is described in the next chapter. 


\section{Chapter 3: Methodology}

This chapter presents the methodology used to answer the research questions presented in Chapter 1. It discusses how the participants were chosen, the methodology used for data collection, as well as the data analysis methods applied.

\section{Classes and Selection of Participants}

Three sections of a French Composition Class at Kent State University were used for this study:

- Section of Fall 2014, French Composition and French Composition Extended: control class 1

- Section of Fall 2015, French Composition and French Composition Extended: control class 2

- Section of Spring 2016, French Composition and French Composition Extended: experimental class

Those classes were fifteen-week courses with a break of three days for Thanksgiving for the Fall sections, and a week of Spring Break for the Spring section. Each section of those courses was divided in two classes: French Composition, and Composition Extended. These are normally considered as two classes of three and two credit hours respectively, but they actually form a single composition class, with the same students and the same material. The same novel, Pêcheur d'Islande (1886) by Pierre Loti, selected by the coordinator of the course was used as 
reading material and basis for the compositions students wrote in those sections. Students also took three tests during the semester including the final exam; all three tests consisted of comprehension questions about the novel and grammar questions. During the semester, students had to answer comprehension questions for each French Composition class meeting time (three times fifty minutes per week). The grammar points studied in class came from the novel, as well as students' mistakes in their answers to the reading questions, and their compositions. The curriculum was decided at the departmental level and the course was set up by the coordinator.

\section{Participants.}

Participants are all undergraduate students enrolled in three French composition classes at Kent State University at the junior level. Some students had French as a minor or as a major. Students from the Fall of 2015 and the Spring of 2016 were presented with a consent form by a third party and were able to opt out of the study if they wished to do so. The writings of the students coming from the Fall of 2014 class were gathered after the course was over. There were fifteen students in the Fall 2014 section of the course, eleven students in the Fall 2015 section of the course, and eight students in the Spring 2016 section of the course. To have the same number of participants for the study in all three groups, eight participants have been chosen randomly in both Fall sections $(2014,2015)$. A questionnaire on a Word document was distributed to the participants in the Fall 2015 and Spring 2016 sections with questions about their translation knowledge and their background in the French language. Among the eight participants, in the 2015 class, five spent some time abroad in a francophone country. In the 2016 class, four students spent some time in a francophone country. All participants had at least four semesters of French. See Appendix A for the questionnaire template. 
For participants to remain anonymous, names were erased from students' papers, and they were replaced by a letter and a number. For the Fall 2014 section: $\__{-} 1, P \_2, P \_3, P \_4, P \_5$, P_6, P_7, P_8. For the Fall 2015 section: $P_{-} a, P_{-} b, P_{-} c, P_{-} d, P_{-}$e, $P_{-} f, P_{-} g, P_{-} h$. For the Spring 2016 section: P_A, P_B, P_C, P_D, P_E, P_F, P_G, P_H. The Fall 2014 section is the control class 1, and no intervention regarding translation was performed in that class. The Fall 2015 section is the control class 2 and one intervention with one translation activity and translation strategy was introduced. The Spring 2016 class is the experimental class, in which several translation activities, as well as translation strategies were introduced.

\section{Method}

\section{Tasks.}

In each class, students are tasked with writing compositions relating to the novel read in class, Pêcheur d'Islande (1886) by Pierre Loti. The first topic for students' compositions was about the author's impressionistic style, and how he particularly made images less clear in readers' minds. The second topic was about how the author uses similes, and the third topic was about how the author made his characters. Here is the class website where the syllabus, as well as the text are available: http://www.personal.kent.edu/ rberrong/fr33212/. The calendars corresponding to each class can be found in Appendices Appendix B, Appendix C, and Appendix D. The present study concentrates on students' compositions at the beginning and at the end of the semester (for the two control classes-Fall 2014, and 2015), and the pre-test and post-test for the class of the Spring of 2016. The pre-test is a summary students were assigned to write of the novel read in class. At that point, students had read a third of the novel. After students were formally introduced to translation strategies in the Spring 2016 class, they wrote 
another summary (post-test). At that moment, students had read the whole novel. See Appendix $\mathrm{E}$ and Appendix $\mathrm{F}$ for an example of a composition and a summary produced by students.

The first composition the students wrote in those classes was written in stages: first, for "draft 1", students searched for examples in the text, sorted them out into categories or themes, then wrote an introduction sentence for each category (draft 2); they added context and an analysis for each example (draft 3), wrote the introduction (draft 4), and then the conclusion (draft 5). The instructor commented on each draft for the first composition, whereas that was not the case for the other compositions. For the two other compositions, students wrote their drafts on their own, and the instructor only commented on the first draft to make sure students were going in the right direction with the examples and categories they chose, but then only the final product was evaluated. The first composition taken into account in the current study from the beginning of the semester (in both control classes of Fall 2014 and 2015) does not contain the changes that students implemented while going through the different drafts mentioned above. The compositions taken into account in this study from the end of the semester (in both control classes of Fall 2014 and 2015) do not contain any form of corrections, as students did not submit each draft in stages as for the first composition. Those are students' genuine writing without any intervention from the instructor. Even though for this study, participants' writings were used without students' revisions based on instructor feedback, it is important to note that students were able to make changes to their writing after the instructor gave feedback.

\section{Translation activities.}

In the control class of Fall 2014, no translation activities were presented to the students, and translation was never mentioned. For the class of the Fall of 2015, only one translation strategy and activity were mentioned: the translation strategy used was transposition (see table 
7), which is a shift in the grammatical category: where English uses a noun, sometimes French will use a verb, for instance. As students had difficulties understanding how French syntax worked and were using the English syntax to write in French, the instructor thought of ways to show the differences between English and French. Here is an example of a sentence a participant wrote:

Ex: *Gaud n'a pas veut pour Yvonne être seule au monde (20 October 2015-control class 2). (The symbol * means that a sentence is not grammatically correct.) The English syntax comes out here: Gaud did not want for Yvonne to be alone in the world. After many grammar-driven exercises that did not help students improve, at the beginning of November 2015, the instructor decided to present translation as a means of communication, and introduced an activity including transposition (a change in the grammatical category). Students became aware of how the French language was functioning. Some of them had an epiphany. Those realizations were happening at that level (upper level course in French) only, and not earlier in the acquisition of the language, which is quite late in the learning process. According to the ACTFL levels of proficiency, generally, students entering the French Composition class are in the intermediate level range (Intermediate low, mid, and high); very few are at an advanced low level. For the Spring 2016 class, after students wrote the first summary, translation strategies were formally introduced in class. Here is the calendar of activities for that class (class was taught in French with some English when necessary): 
Table 9 Calendar of Activities Spring 2016

Day

Wednesday January 202016
Activities

First day of class / syllabus / presentation of the

novel / explanation of the website and review

of passé simple

\begin{tabular}{|c|c|}
\hline Friday January 222016 & $1^{\text {st }}$ reading / answer questions about the text \\
\hline Monday January 252016 & Reading 2 / Causative "faire" \\
\hline Wednesday January 272016 & $\begin{array}{l}\text { Reading } 3 \text { / Direct object and indirect object } \\
\text { complements }\end{array}$ \\
\hline Friday January 292016 & $\begin{array}{l}\text { Reading } 4 \text { / Work on the first draft of the first } \\
\text { essay }\end{array}$ \\
\hline Monday February $1^{\text {st }} 2016$ & $\begin{array}{l}\text { Reading } 5 \text { / grammar - passive voice -Draft } 1 \text { of } \\
\text { first essay due }\end{array}$ \\
\hline Wednesday February 32016 & Reading 6 / What is asked for draft 2 of essay 1 \\
\hline Friday February 52016 & Reading 7 \\
\hline Monday February 82016 & Reading 8 / Work on draft 2 \\
\hline Wednesday February 102016 & $\begin{array}{l}\text { Reading } 9 \text { / grammar - subjunctive - Draft } 2 \text { of } \\
\text { first essay due }\end{array}$ \\
\hline Friday February 122016 & Reading 10 \\
\hline Monday February 152016 & $\begin{array}{l}\text { Reading } 11 \text { / SUMMARY } 1 \text { (Readings 1-11) / } \\
\text { Grammar - how would you say in French (See } \\
\text { Appendix G) }\end{array}$ \\
\hline Wednesday February 172016 & $\begin{array}{l}\text { Readings } 12-13 \text { / Grammar points from students' } \\
\text { answers to the questions about the readings }\end{array}$ \\
\hline
\end{tabular}


Friday February 192016

Monday February 222016
Reading 14 / Grammar points from students' answers to the questions about the readings -

Draft 3 of first essay due

Readings 15-16 / Grammar points from students'

answers to the questions about the readings /

Imagine and write the end of the story

\begin{tabular}{ll}
\hline Wednesday February 242016 & Reading 17 / grammar: find the right answer \\
\hline Friday February 262016 & Reading 18 / Introduction to transposition \\
& (PowerPoint)
\end{tabular}

Monday February 292016

Monday March 72016

Wednesday March 92016

Friday March 112016

Friday March 42016

Monday March 142016
Reading 19/ Transposition - Sentences translated

using transposition. Write a paragraph using the

expressions found while transposing (Activity A)

Readings 20-21 / Review for midterm 1 -

comprehension and grammar

Reading 22 / Review for midterm 1 -

comprehension and grammar

Readings 23-24 / Review for midterm 1 -

comprehension and grammar

Midterm 1 / Work on draft 3

Reading 25 / Introduction to different translation

strategies - Draft 4 of first essay due

Reading 26 / Read the translation of an extract of

reading 1 and determine which translation

strategies have been used by the translator

(Activity B) 
Wednesday March 162016

Friday March 182016

Spring Break March 21-27

Monday March 282016

Wednesday March 302016

Friday April $1^{\text {st }} 2016$

Monday April 42016

Wednesday April 62016

Friday April 82016

Monday April 112016

Wednesday April 132016
Reading 27 - Debate on translation and strategies

Reading 28
Reading 29 - Draft 5 of first essay due

Readings 30-31

Reading 32

Reading 33 / examine the translation of your

classmate

Reading 34 / Back translation from one of

classmates' translation - Draft 1 of second essay

due

Grammar (before and after)

Reading 35 - Work on second essay

Reading 36 - Attract your reader's attention -

(See Appendix H) Work on second essay
Reading 37

Readings 38-39 - Work on second essay

Monday April 182016

Wednesday April 202016

Readings 40-41 / grammar - How to use the

dictionary -

Completed second essay due

Friday April 22 April 2016

Introduction to third essay - Characters in 19th

century novels

Monday April 252016

Wednesday April 272016

Friday April 292016

\section{Second SUMMARY - Review}

Draft 1 of third essay due - Work on third essay 
Monday May 2016

Wednesday May 42016

Friday May 62016
Midterm 2 - Work on third essay

Review of errors in midterm 2

Review for final exam - Completed third essay

due

Translation strategies were introduced and activities using translation were incorporated in that class, but the instructor's priorities were set by the curriculum: to make sure 1) that students understood the novel well, which meant spending time on discussing the text itself as well as on the answers to the questions about the readings, 2) that they were following their composition schedule (having writing time in class with the possibility to ask questions if needed), 3) that they were prepared for the midterm exams (comprehension and grammar questions).

\section{Examples of translation activities.}

Handout given in the 2015 class.

One translation strategy was introduced: transposition (change in grammatical category).

\section{$\underline{\text { Activity A }}$}

Transposition (examples compiled from francaisfacile.com, Intellego.fr, and Vinay \& Darbelnet, 1984)

Adverb/verb

Yann merely nodded. $\rightarrow$ Yann se contenta de faire oui de la tête.

Sylvestre's situation is still critical. $\rightarrow$ La situation de Sylvestre reste critique.

Yann will soon be back from Iceland. $\rightarrow$ Yann ne tardera pas à rentrer d'Islande.

Yann nearly got killed. $\rightarrow$ Yann a failli se faire tuer. 
He nearly got killed. (Remplacez « nearly » par un verbe)

He soon realized his mistake. (Remplacez « soon » par un verbe)

$\underline{\text { Verb/noun }}$

As soon as she got up, Yvonne started singing this awful song. $\rightarrow$ Dès son lever, Yvonne s'est mise à chanter cette chanson affreuse.

Before he comes back to Paimpol, Yann has some fun with other women. $\rightarrow$ Avant son retour à Paimpol, Yann s'amuse avec d'autres femmes.

The day after he returned. (Remplacez "returned" par un nom)

They smiled as he passed by. (Remplacez "passed by" par un nom)

$\underline{\text { Noun/verb }}$

They had much fun at the picnic. (Remplacez "fun" par un verbe)

"Hello", she said with a smile. (Remplacez "smile" par un verbe)

$\underline{\text { Adjective/noun }}$

He constantly refers to his own sources which are understandably but nevertheless annoyingly

anonymous. $\rightarrow$ Il se reporte constamment à ses propres sources, dont l'anonymat est compréhensible mais néanmoins agaçant.

In the early 20th century. (Remplacez "early" par un nom)

She is often seasick. (Remplacez "seasick" par un nom)

Yann's hair was wild as usual. (Remplacez "wild" par un nom)

Other examples of transposition to be completed by students:

(adv-verb) Yann merely smiled when he met Gaud $\rightarrow$ Yann s'est contenté de sourire quand il a rencontré Gaud. 
(adj-noun) I am hungry $\rightarrow$

(adv-noun) It was a lovely day, early in August $\rightarrow$

(verb-noun) People from Paimpol smiled as they passed $\rightarrow$

(noun-verb) This is not Yann's first visit $\rightarrow$

Task: En utilisant les phrases et expressions traduites dans ce document ainsi que dans le document sur la Transposition, écrivez un paragraphe (au moins 15 phrases) sur ce sujet : imaginez la fin de Pêcheur d'Islande (que se passe-t-il pour Gaud et Yann? Et pour Yvonne? Students had to re-use those expressions we worked on in class and found above, and write a paragraph of at least fifteen sentences imagining the end of the novel (what happens with Gaud and Yann? With Yvonne?). They had to anticipate it, as at that point in the semester, we were not done reading the whole novel. Students' writing was evaluated intersententially.

Handouts given in the 2016 class.

The task mentioned above for the Fall 2015 class was used in the Spring 2016 class starting on February 26, 2016, and on February 29, 2016.

Here is a list of the translation strategies that were introduced in class on March 11, 2016:

\section{$\underline{\text { Translation strategies }}$}

Remember, we had talked about transposition, which is a change in grammatical category from one language to another.

Adverb $>$ verb

Ex: Sylvestre's situation is still critical. $\rightarrow$ La situation de Sylvestre reste critique. 
There are other translation strategies that can be useful to think about when you are writing in French.

For example, modulation (change of perspective, of view point) :

Here is a sentence written by a student:

* « Les voisins d'Yvonne l'ont dit qu'elle était demandé à venir au bureau des marins. »

* I guess the corresponding English would be something like:

- "Yvonne's neighbors told her she was asked to come to the fishermen's office."

○ *«Les voisins d'Yvonne l'ont dit qu'elle était demandé à venir au bureau des marins. »

○ Les voisins d'Yvonne lui ont dit qu'on l'a demandait au bureau des marins.

You can notice the literal translation there that actually makes the sentence grammatically incorrect, and prevents naturalness.

In English you say "she was asked to do something...", but in French, you have to change perspectives, and go for: « On lui a demandé d'aller au bureau des marins. » She was asked to go to the sailor's office.

Another sentence written by a student:

*«Le travail physique l'a fait sentir mieux.»

* I guess the corresponding English would be something like:

- "Physical work made him feel better."

○ *«Le travail physique l'a fait sentir mieux. »

In French we would say:

« Il s'est senti mieux grâce au travail physique. » 
Another example of modulation (négatif représenté par positif) :

- "It is not difficult to show that Gaud loves Yann."

○ «Il est facile de démontrer que Gaud aime Yann. »

\section{L'étoffement (amplification)}

Sometimes, the French language needs more information than English. Sometimes one word is not enough, and it needs to be reinforced with others.

Sentence written by a student:

*«Sylvestre a semblé un beaucoup d'adrénaline quand il était tir avec une balle. »

* I guess the corresponding English would be something like:

- "Sylvestre seemed to have a lot of adrenaline when he was shot with a bullet."

○ *«Sylvestre a semblé un beaucoup d'adrénaline quand il était tir avec une balle. »

In French we would say:

« Sylvestre a senti monter l'adrénaline quand on lui a tiré dessus. » (In English you only have « shot », but in French, it's "tiré dessus", we add "dessus").

Another sentence written by a student:

*« Dans la septième lecture Yann et Gaud vont à un mariage, ici on sait que les deux aiment l'autre.»

* I guess the corresponding English would be something like:

- "In the seventh reading, Yann and Gaud go to a wedding, here we know that both love each other." 
○ * « Dans la septième lecture Yann et Gaud vont à un mariage, ici on sait que les deux aiment l'autre. "

In French we would say:

« Dans la septième lecture Yann et Gaud vont à un mariage, ici on sait que les deux amoureux

s'aiment. ")

We needed to add a noun in French "amoureux", otherwise we would lose some meaning.

Amplification of particles with verbs:

- He stopped at the desk for his mail.

$>$ Il s'arrêta au bureau pour prendre son courrier.

- The maid was tearing sheets into strips.

La servante déchirait des draps pour en faire des bandes. (G. Flaubert)

Amplification of particles with adjectives or past participles:

- A man in a blue suit, black shoes, and a grey hat.

$>$ Un homme vêtu d'un costume bleu, chaussé de souliers noirs, et coiffé d'un chapeau gris.

- The inspector on the case.

$>?$ 


\section{Amplification of conjunctions}

- It depends on when you have to go.

$>$ Cela dépend de la date de ton départ.

\section{Explicitation}

An explication of what is implicit in the source language is given in the target language.

- "There is no single solution that will help us make a quick transition or one that fits all."

« Il n’y a pas de solution unique pour nous aider à réaliser une transition rapide, ni de solution applicable à tous. »

\section{Skopos (theory)}

The skopos is the purpose. Translation is a purposeful activity that needs to be adapted to every project. The way you translate, and the final product produced depends on the audience (who are you translating for?). In the same way, your writing in French will depend on who will read your essay. Who are you writing for?

The way you translate a text will change depending on your audience, and on the brief (instructions given to translate) you are given. When you are writing in French, you are paying attention to the brief too. 
Activity B - handout (March 14, 2016)

For example, students had to analyze the translation of an extract of the first chapter of Pêcheur d'Islande; An Iceland Fisherman, translated by Jules Cambon (1902):

Chapitre 1 (Pierre Loti, 1886)

Ils étaient cinq, aux carrures terribles, accoudés à boire, dans une sorte de logis sombre qui sentait la saumure et la mer. Le gîte, trop bas pour leurs tailles, s'effilait par un bout, comme l'intérieur d'une grande mouette vidée ; il oscillait faiblement, en rendant une plainte monotone, avec une lenteur de sommeil.
Chapter 1 (Jules Cambon, 1902)

There they were, five huge, square-built seamen, drinking away together in the dismal cabin, which reeked of fish-pickle and bilgewater. The overhead beams came down too low for their tall statures, and rounded off at one end so as to resemble a gull's breast, seen from within. The whole rolled gently with a monotonous wail, inclining one slowly to drowsiness.

Instructions:

- Identify the translation strategies used by the translator

- Propose your own translation while thinking about an audience (purpose, skopos)

- Compare with the translation of your peers (April 6, 2016)

The outcomes of this activity were that students agreed and disagreed on their peers' translation choices especially when given a specific target audience: the debate was about contemporizing or not; they noticed that naturalness was lacking sometimes, as they were translating at the word level and not at the sentence level. They realized that they had to step back from the linguistic sign and look at the text as a whole. Students, as novice translators were not at a level advanced enough to be able to produce natural sentences in French containing archaisms or to render the text perhaps natural sounding for the time (1886).

\section{Students' writings.}

Each computer file containing participants' writings (compositions for the control classes 2014 and 2015, and pre-test summary-post-test summary for the experimental Spring 2016 
class) were renamed with the participant letter and number discussed at the beginning of this chapter ( $\mathrm{P} \_\mathrm{A}_{-} \mathrm{P}_{-} \mathrm{a} ; \mathrm{P}_{-} 1$; etc. $)$. Students' names and citations from the novel were taken out of students' compositions for anonymity and to be able to count the number of words and sentences exclusively produced by each participant. The corpus consists of 24 texts and 28,041 words total. The number of words was determined for each Word document file from Microsoft Office ${ }^{\circledR}$ Word's word count. Sentences have been counted with an online tool called Count Wordsworth (http://countwordsworth.com/sentences).

Each sentence was then coded or tagged manually with: $<1>$ for wrong lexical/grammatical choice: wrong word for the context, gender of articles, verb forms

Ex: Il y a une tempête qui $<1>$ poser des problèmes aux marins.

$<2>$ Awkward form: (grammatically or semantically deviant sentences)

Ex: Avant de partir de Sylvestre pour la guerre en Chine...<2>.

$<2>$ deviant sentences were also counted when the sentence included error $<1>$ and impaired understanding or made the sentence sound awkward.

$<\mathrm{NG}>$ Natural and grammatically correct

Ex: Il y a une fête qui s'appelle le pardon des Islandais $<\mathrm{NG}>$.

$<\mathrm{NG}>$ Natural, grammatically incorrect

$<\mathrm{GN}>$ Grammatically correct, but not natural

$<$ L1M $>$ L1 Match: structural parallelism with the L1: unnatural but grammatically correct 
Ex:

French : Elle | était $\mid$ en $\mid$ peine $<$ L1M $>$.

English : She | was | in | pain.

Correct translation: Elle avait de la peine. Or: Elle était triste.

That coding was inspired by Kobayashi and Rinnert's error coding (1992).

Three native speakers from France (two living in the US and one living in France) were

consulted to determine if the sentences sounded natural (sentences could be grammatically

correct, or not) according to Owen's method that stipulates that to determine if a sentence sounds

natural, a native speaker has to say so (1988).

\section{Corpus concordance search.}

In order to check that the sentences marked $<\mathrm{NG}>$ were natural, they were extracted from students' writings using the WordSmith software while searching for the $<\mathrm{NG}>$ tag. Nominal groups or clauses of these sentences that could be problematic were then entered in the online Canadian corpus Concordancier-Corpus français https://lextutor.ca/conc/fr/ to see if there was at least one similar instance that collocated. Students' sentences were quite straightforward; their level of French was not high enough to have poetic or uncommon phrases that would sound natural but would not be grammatically correct. When no instance was found in the Concordancier, Google.fr searches were performed using quotation marks to obtain hits for the exact phrase. That is a method used by translators to verify the popularity of an expression. Ex: Il y a une fête qui s'appelle le pardon des Islandais $<\mathrm{NG}>$. (Spring 2016, Summary one, P_a). The researcher concentrated on the hits found in trustable sources such as books and official websites. 
Figure 2 Example of concordance search for the verb "s'appeler"

Onze à présenter un spectacle qui s' APPELLE C'est pour toi que je fais ça.

The sentence would not be considered as natural if at least one of the features in the sentence would not normally occur with the verb "s'appeler".

All the files were converted into .txt files for WordSmith to be able to process them and extract them from the texts. Spaces around the tag brackets were important in order to obtain the best results, and for all the tags to be taken into account in each file.

\section{SPSS $^{\circledR}$.}

Statistics were used to compare each student' progress in writing at the beginning of the semester and at the end of the semester for the classes of Fall 2014 and 2015 and for the pre-test and post-test of the class of Spring 2016. A statistics evaluator was consulted at the Research and Evaluation Bureau at Kent State University. The evaluator helped to decide which tests to use for the study, and also how to report the results.

Two types of tests were considered for analyzing the data for this study: paired sample ttests, and a repeated measures ANOVA. The use of paired-sample t-tests could be justified by the fact that the dependent variables were not controlled the same way: summaries were used in the experimental class, and compositions were used in the two control classes. Those tests would show what is happening in each group, without comparing the groups to each other. However, by conducting multiple paired sample t-tests, the type I error rate alpha $(\alpha)$ or significance level is inflated. The type I error is the fact that the null hypothesis (commonly accepted hypothesis) $\mathrm{H}_{0}$ is rejected when it should not be. "The type I error rate is inflated" means that each time the test is run (the tests would be run three times, one time for each class), the alpha ( $\alpha$ ) value .05 
changes, which would give us erroneous results or at least less reliable results. As the tests are run three times, each time there is a chance to make that error.

As an alternative, then, a repeated measures ANOVA was run three times-one for each dependent variable: wrong lexical/grammatical choice, deviant sentences, and natural sentences - with a between-subjects factor, to examine differences between groups. However, this analysis is also limited by the small sample size $(n=24)$. The repeated measures ANOVA did not show a main effect for group and no interaction effect between group and time, so to see which group or groups changed from pre to post (in each class, each student's progress was measured at the beginning and at the end of the semester or in the pre-test phase and post-test phase for the Spring 2016 class), post-hoc one-tailed paired sample t-tests were run (the SPSS software only allows for two-tailed results. To obtain the one-tailed results, the significance obtained ( $\mathrm{p}$ value) was divided by two). The purpose was to see then if for each group there was a decrease in wrong lexical/grammatical choice and deviant sentences, and if there was an increase in natural sentences. As three paired sample t-tests were run, the probability of receiving at least one significant result increased. So, in order to account for the alpha inflation (or type I error), a Bonferroni adjustment was used. This correction enables the researcher to maintain an overall confidence coefficient. With the Bonferroni adjustment, the significance level for the post-hoc tests was set at $\alpha /$ the number of tests conducted or $.05 / 3=.016$.

To obtain the means used in the statistical tests, the number of lexical/grammatical choice errors $<1>$, deviant sentences $<2>$, and natural sentences $<\mathrm{NG}>$ were computed. For each participant, in each class, there are three sets of data (one set for each class), which were prepared in Microsoft Excel and were then input in SPSS ${ }^{\circledR}$. The following divisions help manage discrepancies, as summaries and compositions were of different length. 
Set of data for the two control classes:

1. Lexical/grammatical choice (beginning of the semester and end of the semester): \# lexical/grammatical errors $\div$ Total \# words in the text

2. Deviant sentences (beginning of the semester and end of the semester):

\# deviant sentences $\div$ Total \# sentences in the text

3. Natural sentences (beginning of the semester and end of the semester):

\# natural sentences $\div$ Total \# sentences in the text

Set of data for the experimental class

1. Lexical/grammatical choice (pre-test and post-test):

\# lexical/grammatical errors $\div$ Total \# words in the text

2. Deviant sentences (pre-test and post-test):

\# deviant sentences $\div$ Total \# sentences in the text

3. Natural sentences (pre-test and post-test):

\# natural sentences $\div$ Total \# sentences in the text

"Pre-test and post-test", as well as "beginning of the semester and end of the semester" will both simply be called "before and after" for simplicity purposes for the rest of this study.

The pages showing the detailed breakdown of the data used have been removed to protect the researcher's copyrights. The results are discussed in the following chapter. 


\section{Chapter 4: Results and analysis}

This chapter discusses the results of the tests presented in Chapter 3, as well as the analysis of those results.

\section{Results from the Sentence Coding}

Sentences were coded for wrong lexical/grammatical choice, deviant sentences, and natural sentences in students' writings before and after in all three classes or groups. In the control class 1 (Fall 2014), the corpus had 10,421 words. Here is a table showing the breakdown of the number of sentences and words for that class before and after:

Table 10 Total Number of Lexical/grammatical Choice Errors, Deviant sentences, Natural Sentences, Sentences, and Words before and after (Fall 2014)

\begin{tabular}{cccccc} 
& $\begin{array}{c}<> \\
\text { Lexical/grammatical } \\
\text { choice errors }\end{array}$ & $\begin{array}{c}<2> \\
\text { Deviant } \\
\text { sentences }\end{array}$ & $\begin{array}{c}<\mathrm{NG}> \\
\text { Natural } \\
\text { sentences }\end{array}$ & Sentences & Words \\
\hline Before & 387 & 166 & 68 & 246 & 4388 \\
\hline After & 451 & 206 & 100 & 327 & 6033 \\
\hline
\end{tabular}


In the Fall 2014 class with no translation intervention, there were more wrong lexical/grammatical choice errors after compared to before. There were more deviant sentences after compared to before, and there were more natural sentences after compared to before.

In the control class 2 (Fall 2015), the corpus size was 12,735 words. Here is a table showing the breakdown of the number of sentences and words for that class before and after:

Table 11 Total Number of Lexica/grammatical l Choice Errors, Deviant sentences, Natural Sentences, Sentences, and Words before and after (Fall 2015)

\begin{tabular}{cccccc} 
& $\begin{array}{c}<1> \\
\text { Lexical/grammatical } \\
\text { choice errors }\end{array}$ & $\begin{array}{c}<2> \\
\text { Deviant } \\
\text { Sentences }\end{array}$ & $\begin{array}{c}<\mathrm{NG}> \\
\text { Natural } \\
\text { sentences }\end{array}$ & Sentences & Words \\
\hline Before & 494 & 209 & 53 & 276 & 4483 \\
\hline After & 497 & 301 & 175 & 492 & 8250 \\
\hline
\end{tabular}

In that class (Fall 2015) in which one translation strategy and activity were introduced, there were more wrong lexical/grammatical choice errors after compared to before, there were more deviant sentences after compared to before, and there were more natural sentences after compared to before.

In the experimental class (Spring 2016), the corpus size was 4,887 words. Here is a table showing the breakdown of the number of sentences and words for that class before and after: 
Table 12 Total Number of Lexical/grammatical Choice Errors, Deviant sentences, Natural Sentences, Sentences, and Words before and after (Spring 2016)

\begin{tabular}{cccccc} 
& $\begin{array}{c}<1> \\
\text { Lexical/grammatical } \\
\text { choice errors }\end{array}$ & $\begin{array}{c}<2> \\
\text { Deviant } \\
\text { Sentences }\end{array}$ & $\begin{array}{c}<\mathrm{NG}> \\
\text { Natural } \\
\text { sentences }\end{array}$ & Sentences & Words \\
\hline Before & 211 & 112 & 21 & 144 & 1957 \\
\hline After & 190 & 127 & 75 & 227 & 2930 \\
\hline
\end{tabular}

In that class (Spring 2016), in which several translation strategies and activities were introduced, there were less wrong lexical/grammatical choice errors after compared to before, there were more deviant sentences after compared to before, and there were more natural sentences after compared to before.

Some sentences were difficult to classify in the "deviant" or "natural" category. They were coded as $<\mathrm{L} 1 \mathrm{M}>$ structural parallelism with the L1: unnatural but grammatically correct , $<\mathrm{NG}>$ Natural, grammatically incorrect, and $<\mathrm{GN}>$ Grammatically correct, but not natural.

Table 13 Total Number $\langle L 1 M>,<N G>$, and $\langle G N>$ in the Whole Corpus Total

\begin{tabular}{lc}
\hline$<$ L1M $>$ sentences & 4 \\
\hline$<$ NG $>$ Natural, grammatically incorrect & 2 \\
\hline$<$ GN $>$ Grammatically correct, but not natural & 17 \\
\hline
\end{tabular}


What follows are participants' literary translated sentences, natural but grammatically incorrect, and grammatically correct but unnatural sentences documented in detail: 
Table 14 Specific Awkward Sentence Types

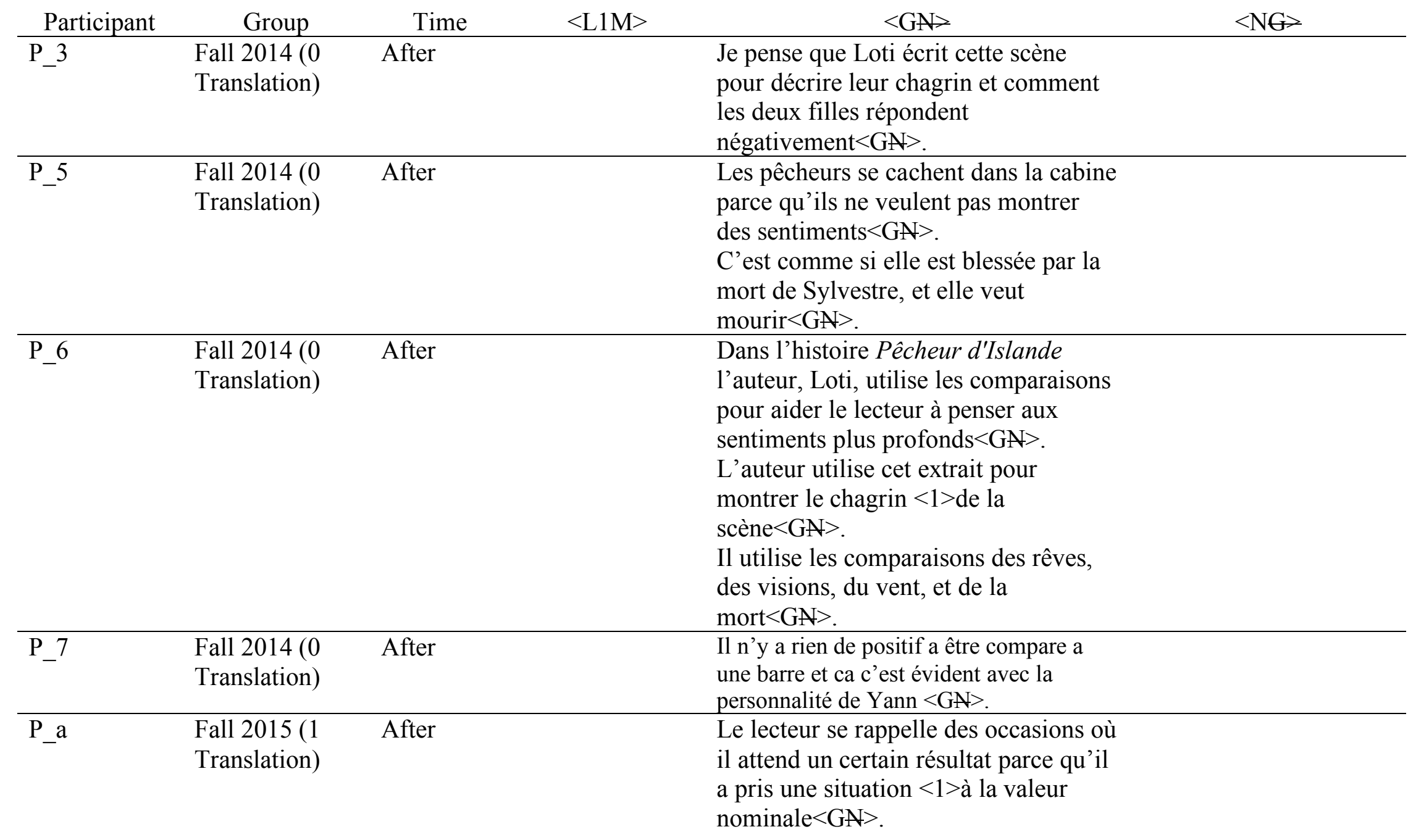




\begin{tabular}{|c|c|c|c|c|c|}
\hline & & & & $\begin{array}{l}\text { À ce moment dans Pêcheur d'Islande, } \\
\text { la vie de Gaud éprouve beaucoup de } \\
\text { changement }<1><\mathrm{GN}>\text {. }\end{array}$ & \\
\hline P_c & $\begin{array}{l}\text { Fall } 2015 \text { (1 } \\
\text { Translation) }\end{array}$ & After & $\begin{array}{l}\text { Elle a } \\
<1>\text { beaucoup de } \\
\text { stress depuis la } \\
\text { perte de son } \\
\text { amour, et Loti } \\
\text { écrit... }<\text { L1M }>\text {. }\end{array}$ & $\begin{array}{l}\text { Une nuit après la disparition de Yann, } \\
\text { c'était très tard et il y a un coup sur sa } \\
\text { porte }<\mathrm{GN}>\text {. }\end{array}$ & \\
\hline P_e & $\begin{array}{l}\text { Fall } 2015 \text { (1 } \\
\text { Translation) }\end{array}$ & After & & $\begin{array}{l}\text { En refusant cela, Yann s'est dégoûté } \\
\text { de lui-même parce que son sort aura } \\
\text { été sa mort à ce rythme }<\mathrm{GN}>\text {. }\end{array}$ & \\
\hline P_D & $\begin{array}{l}\text { Spring } 2016 \\
(2+ \\
\text { Translation })\end{array}$ & After & & Ça laisse Gaud très pauvre $<\mathrm{GN}>$. & $\begin{array}{l}\text { Gaud et sa grande tante } \\
\text { (Yvonne) écrivent une } \\
\text { lettre à envoyer à } \\
\text { Sylvestre }<\text { NG }>\text {. }\end{array}$ \\
\hline P_F & $\begin{array}{l}\text { Spring } 2016 \\
(2+ \\
\text { Translation })\end{array}$ & After & & $\begin{array}{l}\text { En même temps Yann part pour la } \\
\text { pêche en Islande }<\mathrm{GN}>\text {. } \\
\text { Yann accompagne les deux femmes à } \\
\text { leur petite chaumière pauvre }<\mathrm{GN}>\text {. }\end{array}$ & $\begin{array}{l}\text { A Paimpol Gaud voit } \\
\text { que Yann parle et se } \\
\text { promène avec des autres } \\
\text { femmes pas } \\
\text { respectables }<\mathrm{NG}>\text {. }\end{array}$ \\
\hline P_G & $\begin{array}{l}\text { Spring } 2016 \\
(2+ \\
\text { Translation })\end{array}$ & After & $\begin{array}{l}\text { Sylvestre et } \\
\text { Yann, sont } \\
\text { meilleur }<1> \\
\text { amis }<\text { L1M }>\text {. }\end{array}$ & $\begin{array}{l}\text { Il y a une tempête qui montre } \\
\text { l'importance de l'atmosphère et }<1> \\
\text { la mer dans l'histoire }<\mathrm{GN}>\text {. }\end{array}$ & \\
\hline $\mathrm{P} \_\mathrm{H}$ & $\begin{array}{l}\text { Spring } 2016 \\
(2+ \\
\text { Translation })\end{array}$ & After & $\begin{array}{l}\text { Les deux } \\
\text { hommes sont } \\
\text { appelés } \\
\text { Sylvestre et } \\
\text { Yann, et ils sont } \\
\text { des } \\
\text { amis }<\text { L1M }>\text {. }\end{array}$ & $\begin{array}{l}\text { Le roman Pêcheur d'Islande } \\
\text { commence avec un bateau à la mer et } \\
\text { des hommes }<\mathrm{GN}>\text {. } \\
\text { Le roman est terminé avec la mort de } \\
\text { Yann, finalement dans la mer }<\mathrm{GN}>\text {. }\end{array}$ & \\
\hline
\end{tabular}


Les deux sont contents pour le moment $<$ LI M $>$.

82 
Those sentences appear in all three groups, but only after, not before.

Some sentences were also problematic, as they were considered as natural by one native speaker, but not by the other. They were still counted in the natural sentences category. 
Table 15 Sentences Difficult to Classify (Naturalness)

\begin{tabular}{|c|c|c|c|c|c|}
\hline & \multirow[b]{2}{*}{ Participant } & \multirow[b]{2}{*}{ Sentence } & \multicolumn{2}{|c|}{ Native Speaker 1} & \multirow{2}{*}{$\begin{array}{c}\text { Native speaker } \\
2 \\
\text { Comments } \\
\end{array}$} \\
\hline & & & Natural & Not natural & \\
\hline 1 & Fal12014_C1_P_5 & $\begin{array}{l}\text { Le style d'écriture en général est utilisé pour une variété de } \\
\text { raisons. }\end{array}$ & & $\begin{array}{c}\text { X « variété » mal } \\
\text { employé, pour } \\
\text { « plusieurs » raisons } \\
\text { The word « variété » } \\
\text { is ill employed. } \\
\text { « pour } \\
\text { plusieurs raisons » is } \\
\text { correct. }\end{array}$ & $\begin{array}{l}\text { The word } \\
\text { " variété » was } \\
\text { considered to be } \\
\text { ok here, and in } \\
\text { the students" } \\
\text { feedback. }\end{array}$ \\
\hline 2 & Fal12014_C1_P_6 & L'auteur de l'histoire dépeint la nature ancienne du soleil. & $\mathrm{X}$ & & \\
\hline 3 & Fal12014_C2_P_5 & $\begin{array}{l}\text { Loti décrit Yvonne comme un animal pour illustrer sa tristesse } \\
\text { complète. }\end{array}$ & & $\begin{array}{c}\mathrm{X} \text { « complète »: } \\
\text { « sa profonde } \\
\text { tristesse »? }\end{array}$ & $\begin{array}{l}\text { The word } \\
\text { " complète » } \\
\text { was considered } \\
\text { to be ok here, } \\
\text { and in the } \\
\text { students' } \\
\text { feedback. }\end{array}$ \\
\hline 4 & Fall2015_C1_P_c & Ce paysage donne une vue du paradis. & $\mathrm{X}$ & & \\
\hline 5 & Fall2015_C2_P_b & $\begin{array}{l}\text { La santé d'Yvonne est très mauvaise et elle doit rester à sa } \\
\text { maison. }\end{array}$ & & $\mathrm{X}$ « à la maison » & $\begin{array}{l}\text { It is ok, French } \\
\text { children } \\
\text { sometimes write } \\
\text { that this way. }\end{array}$ \\
\hline 6 & Fall2015_C2_P_b & $\begin{array}{l}\text { Gaud touche le fond et le lecteur comprend comment on se } \\
\text { sent quand les pressions du monde deviennent trop difficiles. }\end{array}$ & & $\begin{array}{c}\mathrm{X} \text { « touche le fond » } \\
\text { un peu trop } \\
\text { populaire, sinon } \\
\text { phrase ok. }\end{array}$ & Style issue. \\
\hline 7 & Fall2015_C2_P_b & Après cet exemple, le lecteur comprend fermement Gaud. & & $\begin{array}{l}\mathrm{X} \text { «Suite à cet } \\
\text { exemple... }\end{array}$ & Style issue. \\
\hline 8 & Fall2015_C2_P_b & $\begin{array}{l}\text { Près de la fin de chapitre dix-neuf, Yvonne envoie une lettre à } \\
\text { Sylvestre. }\end{array}$ & & $\begin{array}{l}\text { X A la fin du } \\
\text { chapitre... }\end{array}$ & \\
\hline
\end{tabular}


9 Fall2015_C2_P_d Ils parlent de la situation avec l'argent aussi.

10 Fal12015_C2_P_e Encore une fois, il y a la reconnaissance des épreuves de la vie quotidienne de Gaud.
$\mathrm{X}$ du problème de

l'argent

$\mathrm{X}$ reconnaissance à It is correct,

remplacer

though.

should be replaced 
The sentences presented in Table 15 were difficult to classify as natural or not. For Sentence number 1, Native speaker 1 would have preferred the adjective "plusieurs" instead of the noun "variéte", but both could be used. For sentence 3, native speaker 1 did not like the adjective "complète" combined with the noun "tristesse", but it is not impossible to find those two together, as it was the case with Concordancier-corpus français.

Figure 3 "Tristesse complète" in Concordancier-corpus français

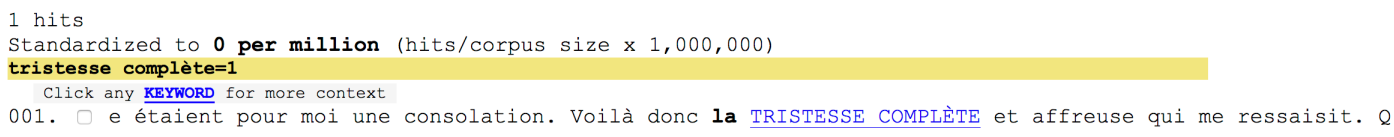

For sentence 5, while it is true that "elle doit rester à la maison" is what should be said, it is not impossible to hear the phrase "elle doit rester à sa maison" using the possessive "sa" in French for "her house", especially when French children express themselves. It is also not uncommon to encounter that expression with the possessive in the written form.

Figure 4 "à sa maison" in Concordancier-corpus français

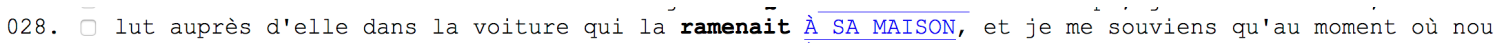

Sentence 8 uses "près de la fin de" with the noun "chapitre". In French, we would rather say "vers la fin du chapitre" (towards the end of the chapter) or "à la fin du chapitre" as proposed by Native speaker 1, but that would be "at the end of the chapter", which is slightly different in meaning. However, an instance in Concordancier-corpus français helps us think that "près de la fin" is acceptable:

Figure 5 "près de la fin" in Concordancier-corpus français

001. $\square$ s se rendit à table, le premier comme d'habitude. PRÈS DE LA FIN du repas, il se leva et prit la par 
Normally, one would expect "vers la fin du repas" (towards the end of the meal) and not "près de la fin du repas" found in the Concordancier-corpus français. However, it is an instance that is possible. Sentence 9 did not have any justification within the Concordancier-corpus français. Native speaker 2 still found that this sentence sounded natural. In Sentence 10, the issue was "reconnaissance", but the researcher checked in the monolingual French dictionary, and its usage is totally fine in that context, in the sense of "recognition". It can be noted that Native speaker 1 just commented that the noun "reconnaissance" needed to be changed, but no alternative was offered.

\section{Results from the Concordance Search}

The sentences marked as natural by the native speakers were checked in the Concordancier-corpus français online. Each unit of meaning in those sentences was entered in the concordance search to see if they were similar collocates. The following examples illustrate some of the findings. Please see Appendix K and Appendix L for more examples. Some of the instances checked in the Concordancier-corpus français had no corresponding matches, but then the Google.fr searches enabled the researcher to decide about the status of the sentence. 
Table 16 Excerpt of Concordance Search Results for the Fall 2014 Class' First Composition

\begin{tabular}{|c|c|c|c|}
\hline Participant & Sentence & String used & Results \\
\hline$P_{-} 1$ & $\begin{array}{l}\text { En écrivant ça, } \\
\text { il explique } \\
\text { comment les } \\
\text { gens l'utilisent } \\
\text { pour tous les } \\
\text { types de } \\
\text { prières. }\end{array}$ & $\begin{array}{l}\text { En écrivant } \\
\text { Explique } \\
\text { comment }\end{array}$ & 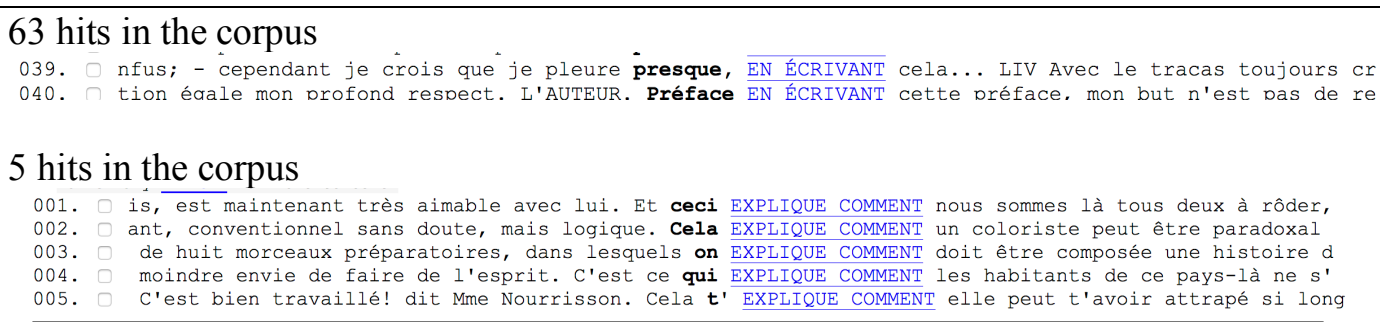 \\
\hline P_2 & $\begin{array}{l}\text { Les pêcheurs } \\
\text { préparaient les } \\
\text { poissons. }\end{array}$ & $\begin{array}{l}\text { Préparer les } \\
\text { poissons }\end{array}$ & 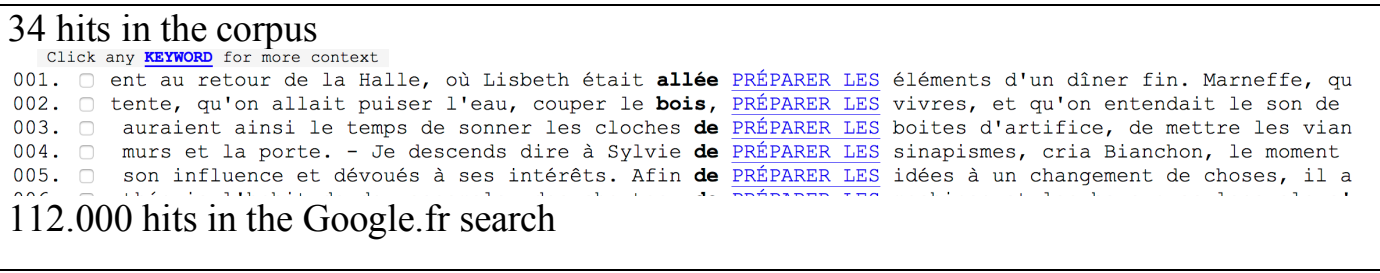 \\
\hline $\mathrm{P} 33$ & $\begin{array}{l}\text { Plus tard dans } \\
\text { le roman, elle } \\
\text { est } \\
\text { impressionnée } \\
\text { par sa taille et } \\
\text { ses muscles. }\end{array}$ & $\begin{array}{l}\text { impressionnée } \\
\text { par }\end{array}$ & 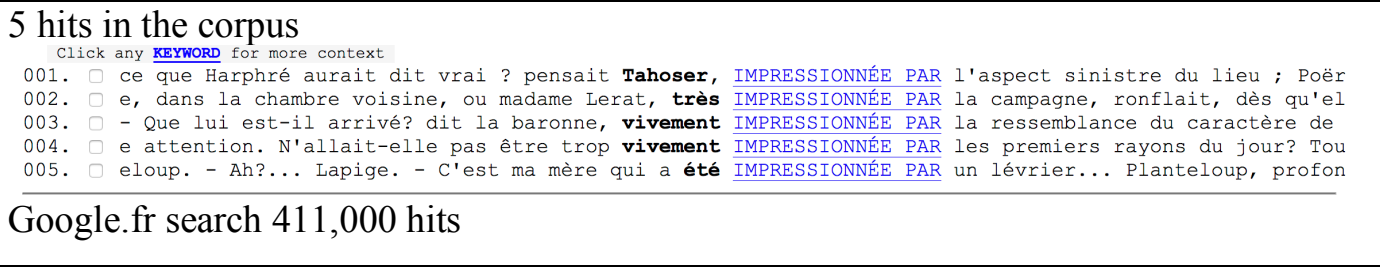 \\
\hline $\mathrm{P}_{-} 4$ & $\begin{array}{l}\text { Dans la } \\
\text { citation, la } \\
\text { lumière semble } \\
\text { plus puissante } \\
\text { parce qu'elle est } \\
\text { compactée et } \\
\text { pousse les } \\
\text { ténèbres loin. }\end{array}$ & $\begin{array}{l}\text { Lumière } \\
\text { compactée }\end{array}$ & $\begin{array}{l}\text { None in the corpus. Google.fr search performed. } \\
\text { Very few results (9), including two books, one of them from } 1828 \text {. } \\
\text { "Dans notre ordre des choses actuel, tout dans la création a pour voile les ténèbres, qui ne } \\
\text { sont que la lumière compactée, et si, par la puissance colérique, qui est la seule que nous } \\
\text { possédions, nous brisons ce voile, les corps ne peuvent nous offrir que les merveilles } \\
\text { infernales." (Mure Latour, 1828, p. 136) } \\
\text { "Dans la lumière compactée par la colère, existe le germe de toutes les furies et de tous } \\
\text { les maux que pet enfanter l'abyme." (Mure Latour, 1828, p. 119) } \\
\text { "Lumière compactée en un seul point d'arrivée, comme piégée de sa propre absence } \\
\text { (...)." (Carré, 2015, p. 22) }\end{array}$ \\
\hline P_5 & $\begin{array}{l}\text { Plutôt, les } \\
\text { pêcheurs sont } \\
\text { comme un fruit } \\
\text { de }\end{array}$ & $\begin{array}{l}\text { Sont comme } \\
\text { Plutôt, ils }\end{array}$ & $\begin{array}{l}118 \text { hits in the corpus } \\
\text { 005. s'interrogent. "On ne sait rien. Ceux qui font ça sonT comME les cafards. On croit en être venu à bo }\end{array}$ \\
\hline
\end{tabular}




\begin{tabular}{|c|c|c|c|}
\hline & $\begin{array}{l}\text { l'imagination } \\
\text { de l'auteur. }\end{array}$ & & $\begin{array}{l}\text { None in the corpus. Google.fr search } 108,000 \text { hits. "Plutôt, ils trouvent leur nourriture } \\
\text { grâce à la chimioréception, un processus (...)." (Bryce, 2017, par. 3) Translated from } \\
\text { English by Juliette Colinas. }\end{array}$ \\
\hline P_6 & $\begin{array}{l}\text { Sinon, il ne } \\
\text { peut pas } \\
\text { comprendre le } \\
\text { sens plus } \\
\text { profond de } \\
\text { Pêcheur } \\
\text { d'Islande. }\end{array}$ & $\begin{array}{l}\text { Le sens plus } \\
\text { profond }\end{array}$ & $\begin{array}{l}\text { None in the corpus. Google.fr search performed. } 64,100 \text { hits. } \\
\text { Match found in several Google Books. } \\
\text { "Elle laissait apparaître le sens le plus profons de la maladie mortelle comme derière } \\
\text { conquête de soi de sa vie.” (Fink, 1976, p. 61) This book has been translated from } \\
\text { German. } \\
\text { "(...) il a découvert, derrière le sens littéral de l'Ecriture sainte (de l'ancien Testament)le } \\
\text { sens plus profond, le sens spirituel. » (Drobner, 1999, p. 123). Translated from German. } \\
\text { "Il distingue en général dans ces occasions un double sens scriptuaire, la lettre et le sens } \\
\text { plus profond.” (Bardenhewer, 1899, p. 325). Translated from German. } \\
\text { "(...) On aboutit enfin à la sententia qui est le sens plus profond que l'auteur a voulu } \\
\text { attacher à son texte.” (Chardonnens, 1997, p. 7) }\end{array}$ \\
\hline \multirow[t]{2}{*}{$P_{-} 7$} & $\begin{array}{l}\text { Il utilise des } \\
\text { procédés pour } \\
\text { décrire la scène, } \\
\text { les }\end{array}$ & $\begin{array}{l}\text { Afin de rendre }+ \\
\text { noun }\end{array}$ & 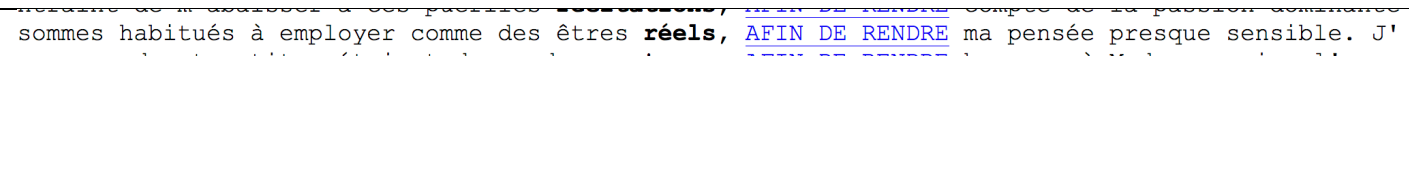 \\
\hline & $\begin{array}{l}\text { personnages, et } \\
\text { la religion, afin } \\
\text { de rendre son } \\
\text { histoire plus } \\
\text { incertaine pour } \\
\text { ses lecteurs. }\end{array}$ & $\begin{array}{l}\text { Histoire plus } \\
\text { incertaine }\end{array}$ & $\begin{array}{l}\text { None in the corpus. Google.fr search performed. } \\
8 \text { results. }\end{array}$ \\
\hline P_ 8 & $\begin{array}{l}\text { Premièrement, } \\
\text { il nous vole le } \\
\text { sens de la vue } \\
\text { en écrivant une } \\
\text { vague et } \\
\text { sombre } \\
\text { description de } \\
\text { la mer quand il } \\
\text { dit... }\end{array}$ & $\begin{array}{l}\text { Ecrire une } \\
\text { description }\end{array}$ & None in the corpus. Google.fr search performed. 123,000 results. \\
\hline
\end{tabular}


The search had to be adapted. If no matches were found in the corpus, a Google.fr search was performed, as other peer reviewed corpora in French are not so common. All the sentences that had been marked as natural by the native speakers had matches either in the corpus or in Google searches. Some of the strings were repeated in other sentences, so they were not searched a second time. In the table above, it is worth noticing that sentences for participants $\mathrm{P} \_5$ and $\mathrm{P} \_6$ the strings "Plutôt" and "le sens plus profond" were found in books that have been translated from English and German respectively. It is rare to see the adverb "plutôt" in French at the beginning of a sentence, but it is possible to use it that way.

\section{Results from the Statistical Analysis}

Three repeated measures ANOVAs for each dependent variable (wrong lexical/grammatical choice, deviant sentences, and natural sentences) with a between-subjects factor was performed in the SPSS software with descriptive statistics obtained for each group: For the two control classes:

4. Lexical/grammatical choice (beginning of the semester and end of the semester): \# lexical/grammatical errors $\div$ Total \# words in the text

5. Deviant sentences (beginning of the semester and end of the semester):

\# deviant sentences $\div$ Total \# sentences in the text

6. Natural sentences (beginning of the semester and end of the semester):

\# natural sentences $\div$ Total \# sentences in the text

For the experimental class:

7. Lexical/grammatical choice (pre-test and post-test): \# lexical/grammatical errors $\div$ Total \# words in the text 
8. Deviant sentences (pre-test and post-test):

\# deviant sentences $\div$ Total \# sentences in the text

9. Natural sentences (pre-test and post-test):

\# natural sentences $\div$ Total \# sentences in the text

Following is a descriptive table representing the standard deviation for each group for each dependent variable.

Table 17 Mean and Standard Deviation Before and After

\begin{tabular}{ccccc} 
& Group & $\begin{array}{c}\text { Mean (Std. } \\
\text { Deviation) } \\
\overline{\mathrm{x}}(\mathrm{SD})\end{array}$ & $\begin{array}{c}\text { Mean (Std. } \\
\text { Deviation) } \\
\overline{\mathrm{x}}(\mathrm{SD})\end{array}$ & $\begin{array}{c}\text { Number of } \\
\text { participants (n) }\end{array}$ \\
\hline $\begin{array}{c}\text { Lexical/gram } \\
\text { choice }\end{array}$ & 0 Translation & $.08(.03)$ & $.07(.03)$ & 8 \\
& 1 Translation & $.11(.04)$ & $.05(.03)$ & 8 \\
& $2+$ Translation & $.10(.02)$ & $.06(.02)$ & 8 \\
\hline $\begin{array}{c}\text { Deviant } \\
\text { sentences }\end{array}$ & 0 Translation & $.66(.20)$ & $.60(.17)$ & 8 \\
& 1 Translation & $.74(.13)$ & $.66(.13)$ & 8 \\
\hline $\begin{array}{c}\text { Natural } \\
\text { sentences }\end{array}$ & 2+ Translation & $.78(.09)$ & $.56(.15)$ & 8 \\
& 1 Translation & $.28(.17)$ & $.32(.18)$ & 8 \\
& 2+ Translation & $.19(.13)$ & $.31(.13)$ & 8 \\
\hline
\end{tabular}

The results from the three repeated measures ANOVAs show that:

For wrong lexical/grammatical choice:

- There was a main effect for time (before and after): $\mathrm{F}(1,21)=26.933, \mathrm{p}<.001$ 
- $\quad$ There was no main effect for group: $F(2,21)=0.27, p=.76$

- There was no interaction effect for group and time: $F(2,21)=3.13, p=.065$

For Deviant sentences:

There was a main effect for time (before and after):: $\mathrm{F}(1,21)=8.79, \mathrm{p}=.007$

Group and time: $\mathrm{F}(2,21)=1.48, \mathrm{p}=.250$

Group: $F(2,21)=.704, p=.506$

For Natural Sentences:

There was a main effect for time (before and after): $F(1,21)=10.87, p=.003$

Group and time: $\mathrm{F}(2,21)=1.303, \mathrm{p}=.293$

Group: $\mathrm{F}(2,21)=.778, \mathrm{p}=.472$

This means that there was a significant difference between before and after, which means that, as expected, participants have improved over time. However, there was no significant difference between the groups. According to the repeated measures ANOVAs, there is no group that performed better than another for wrong lexical/grammatical choice, deviant sentences, and natural sentences.

Since there was a significant difference for time though, it is important then to concentrate on each group and see if there was a significant difference for wrong lexical/grammatical choice, deviant sentences, and natural sentences. Post-hoc paired sample ttests were thus run. The results for the post-hoc paired sample t-tests show that for the control class 1 (Fall 2014-No translation), there was no significant difference before and after for lexical/grammatical choice, deviant sentences, and natural sentences.

One-tailed paired sample t-test results for Fall 2014 ( $\mathrm{p}$ value obtained by dividing the two-tailed $\mathrm{p}$ value by two): 
Lexical/grammatical choice: $\mathrm{t}(7)=.996, \mathrm{p}(1$-tail $)=.177$

Deviant sentences: $\mathrm{t}(7)=.665, \mathrm{p}(1-$ tail $)=.262$

Natural sentences: $\mathrm{t}(7)=-.707, \mathrm{p}(1$-tail $)=.251$

With the Bonferroni correction to maintain an overall confidence coefficient, the significance level or $\mathrm{p}$ value was set at $\alpha / \mathrm{n}$ or $.05 / 3=.016$.

To have a significant difference between before and after for lexical/grammatical choice, deviant sentences, and natural sentences, the p value obtained needs to be less than .016, which is not the case here. The Fall 2014 class did not improve throughout time. It is important to note here again, that students were able to make some changes to their writing after the instructor gave them feedback. All students still made some progress and they all passed the class.

One-tailed paired sample t-test results for Fall 2015 (one translation activity) (p value obtained by dividing the two-tailed $\mathrm{p}$ value by two):

Lexical/grammatical choice: $\mathrm{t}(7)=3.827, \mathrm{p}(1$-tail $)=.003$

Deviant sentences : $\mathrm{t}(7)=1.402, \mathrm{p}(1-$ tail $)=.102$

Natural sentences: $\mathrm{t}(7)=-2.236, \mathrm{p}(1$-tail $)=.03$

With the Bonferroni correction to maintain an overall confidence coefficient, the significance level or $\mathrm{p}$ value was set at $\alpha / \mathrm{n}$ or $.05 / 3=.016$.

To have a significant difference between before and after for lexical/grammatical choice, deviant sentences, and natural sentences, the p value obtained needs to be less than .016 .

For the 2015 class, there was a significant decrease before and after for wrong lexical/grammatical choice. There was no significant decrease before and after for deviant sentences and no significant increase for natural sentences. 
One-tailed paired sample t-test results for Spring 2016 (several translation activities) (p value obtained by dividing the two-tailed $\mathrm{p}$ value by two):

Lexical/grammatical choice: $\mathrm{t}(7)=4.699, \mathrm{p}(1$-tail $)=.001$

Deviant sentences: $\mathrm{t}(7)=3.379, \mathrm{p}(1$-tail $)=.006$

Natural sentences: $\mathrm{t}(7)=-2.783, \mathrm{p}(1$-tail $)=.0135$

To have a significant difference between before and after for wrong lexical/grammatical choice, deviant sentences, and natural sentences, the $\mathrm{p}$ value obtained needs to be less than .016 .

For the Spring 2016 class, there was a significant decrease before and after for wrong lexical/grammatical choice and deviant sentences, and a significant increase in natural sentences. 


\section{Chapter 5: Conclusion}

This chapter presents a discussion of the results, the contributions of this study, as well as its limitations, and recommendations for further research.

\section{Discussion}

The goal of this study was to discover if introducing translation strategies in an undergraduate upper level French composition course had an impact on students' expository writing, specifically in terms of its naturalness. The natural sentences that were marked by several native speakers and then checked in the Concordancier-corpus français showed that naturalness is not that easy to define. "Naturalness" remains quite a subjective concept, and the check in the corpus limits the findings to the grammatically correct natural sentences identified. Even if the data showed not so many sentences marked as sounding natural but not grammatically correct, attesting in the corpus could not give answers for these types of sentences, and they could not be categorized as deviant either. Only the native speaker check could be of help in that case, especially because sentences were marked as natural or not in context. The sentences marked $<\mathrm{NG}>$ (natural but grammatically incorrect) all appear afterafter the translation interventions, and for the experimental class only. As those sentences do not occur in the two other classes, their presence in the experimental class could be explained by the impact of the use of translation strategies and activities in that class. There were not enough sentences found to draw conclusions, but it would be interesting to investigate that further, and 
see if with more translation activities and over a longer period of time, those sentences become more common in students' writing.

The paired sample t-tests that were run show that there was no significant difference before and after for lexical/grammatical choice, deviant sentences, or natural sentences for the control class 1 (Fall 2014); there was significant difference before and after for lexical/grammatical choice, deviant sentences, and natural sentences for the experimental class (Spring 2016); there was a significant difference also before and after for lexical/grammatical choice in the control class 2 (Fall 2015-One translation activity). The fact that there was no significant difference before and after for the control class 1 (Fall 2014), does not mean that students did not improve their writing at all, though, as they were able to make changes to their drafts after the instructor gave them feedback. It does suggest, however, that students in the control class 2 (Fall 2015), and those in the experimental class (Spring 2016) seemed to be at an advantage over the students in the two other classes.

In the experimental class (Spring 2016), and in the control class 1 (Fall 2015), translation strategies were beneficial for the students. The significant difference in the control class 1 (Fall 2015) in lexical/grammatical choice could mean that after being introduced to translation, students would have a stronger sense of lexical/grammatical choice: their use of pronouns, verbs, and articles improved. That would also means that students improved their naturalness in text (Sinclair, 1984). As in the experimental class, there was a significant difference for all three variables — there were fewer lexical/grammatical choice errors, fewer deviant sentences, and more natural sentences - it means that students improved in the three categories of lexical/grammatical choice, deviant sentences, and natural sentences.

In the class of Fall 2014, grammar exercises were used in which students had to correct 
grammatical errors. Even though the grammar topics were studied in class beforehand, for students to see mistakes over and over again and be asked to correct them caused them memorize those mistakes rather than learning from them (negative modeling), which perhaps could explain that there was no significant difference for before and after for lexical/grammatical choice, deviant sentences, and natural sentences for that group. The use of transposition (shift in a grammatical category) in the 2015 class helped students realize that sentences produced in their L1 could not be transferred directly in their L2; they certainly had to transpose grammatical categories to make sentences sound more natural in French.

The use of several translation strategies and translation activities in the experimental class, such as transposition, modulation, amplification, and explicitation, enabled students to experience the differences between their L1 and their L2. Moreover, the use of Skopos theory also helped the students visualize their audience, and their goal while translating, and also while writing in their L2.

\section{Contributions of this Study}

In composition studies, the teaching techniques or elements taken into account while teaching how to write in a foreign language include: genre-based learning (Yasuda, 2011), features of text, composing or writing processes, sociocultural contexts (Cumming, 2001), and techniques used by good writers such as planning, defining a rhetorical problem, and evaluating solutions (Hyland, 2011, p. 18). For example, novice writers plan less than expert writers. However, non-linear models describing writing as a problem-solving task in which writers go back and forth between their ideas and the different writing stages such as planning, drafting, and revising have been presented (Hyland, 2011). Hyland (2011) also mentions other teaching 
techniques such as focusing on text as discourse, and on readers or the audience, as well as on writing as a social practice. Translation, like writing, is also considered a problem-solving task. It is a social practice, and it also focuses on the target audience. Expert translators also plan more than novice translators, and they use translation strategies in a more automated way (Shreve \& Angelone, 2010). (See Table 18 for similarities between expert writers and expert translators.) Translation is a communication tool, and like writing, it is bound to a certain cultural and social environment. There are many similarities between writing in a second language and translating (see Table 19), and Translation Studies can complement second language writing to make the learning of writing easier for students.

Table 18 Similarities Between Experts in L2 Writing and Experts in Translation in the Way They Achieve Naturalness

\section{Experts in L2 writing Experts in translation}

Mastering linguistic and cultural competence Mastering linguistic and cultural competence Cohesion Considering the text as a whole Careful planning Automatic choice of translation strategies Genre knowledge Domain knowledge

Table 19 Similarities Between Second Language Writing and Translating

\begin{tabular}{ll}
\multicolumn{1}{c}{ Second language writing } & \multicolumn{1}{c}{ Translating } \\
\hline Communicate ideas to an audience & $\begin{array}{l}\text { Communicate a message in another language } \\
\text { for an audience }\end{array}$ \\
\hline Focus on the audience (cultural competence) & Focus on the audience (cultural competence) \\
\hline Focus on the instructions & Focus on the instructions (brief) \\
\hline $\begin{array}{l}\text { Combine composition theories and practice } \\
\text { (tools like text analysis) }\end{array}$ & $\begin{array}{l}\text { Combine translation theory and practice } \\
\text { (tools) - text analysis }\end{array}$ \\
\hline
\end{tabular}




\begin{tabular}{ll}
\hline Use of corpora & Use of corpora \\
\hline Learn from expert behavior & Learn from expert behavior \\
\hline $\begin{array}{l}\text { Code-switching/code mixing as a form of } \\
\text { translation }\end{array}$ & Domesticating/foreignising \\
\hline
\end{tabular}

\section{Translation and $\mathrm{L} 2$ reading skills - The reading/writing relationship.}

This study can help teachers of foreign languages understand the concept and the benefits of Translation Studies in foreign language education. Translation Studies can contribute by improving not only students' writing skills in the second language, but also their reading, as translators are readers too, and the full circle is completed, as there is evidence that reading helps improving writing competence, and vice versa (Hyland, 2011). Fitzgerald and Shanahan (2000) list three approaches taken in the research of reading and writing: rhetorical reading and writing, procedural connections, and shared knowledge and cognitive processes between reading and writing. For rhetorical reading and writing, both disciplines are used as communication tools, and while reading and writing, individuals learn how communication functions by being senders and receivers. This has a parallel in translation: translators are mediators between two cultures: a source culture (sender) and a target culture (receiver). For procedural connections, reading and writing are considered as functional activities that can be combined to achieve external goals. The research on shared knowledge and cognitive processes between reading and writing has concentrated on four kinds of knowledge that the two disciplines have in common:

metaknowledge, domain knowledge about substance and content, knowledge about universal text attributes, and procedural knowledge and skill to negotiate reading and writing (Fitzgerald and Shanahan, 2000, pp. 39-40) (see Table 20). 
Table 20 Knowledge Categories Common to Readers and Writers (After Fitzgerald and

Shanahan's, 2000, p. 41)

\begin{tabular}{|c|c|}
\hline Metaknowledge & $\begin{array}{l}\text { Being aware of functions and goals of reading and } \\
\text { writing }\end{array}$ \\
\hline & Being aware of readers and writers' interaction \\
\hline & $\begin{array}{l}\text { Being able to track one's own way to produce } \\
\text { meaning }\end{array}$ \\
\hline & Being able to track one's own knowledge \\
\hline Domain knowledge about substance and content & Semantics \\
\hline Knowledge about universal text attributes & $\begin{array}{l}\text { Graphophonics } \\
\text { Syntax } \\
\text { Text format }\end{array}$ \\
\hline $\begin{array}{l}\text { Procedural knowledge and skill to negotiate } \\
\text { reading and writing. }\end{array}$ & $\begin{array}{l}\text { Being able to access, use, and produce knowledge } \\
\text { in the areas above mentioned }\end{array}$ \\
\hline
\end{tabular}

Those knowledge categories in reading-writing in the L1 offer a springboard to investigate the functioning of writing and reading in the L2, and also of reading for translation. Indeed, the reading-writing relationship in the L1 can have an impact on the L2; for instance, Hsu (2004) notes the difference between how Taiwanese students learn their first and second languages: when they learn how to read and write in their L1 (Chinese), they first learn how to write the Chinese characters to then be able to recognize them when they start reading. However, when they start learning their L2 (English), they first start reading and learning many grammar rules, and it is only later that they learn how to write. In North America, writing is the means to literacy (Hsu, 2004, p. 3), but for ESL teaching, for example, reading precedes writing. When learners start the L2, they already have acquired skills in the L1 that may or may not affect their learning of the L2. One can wonder, though, to what extent the L1 can have an impact on L2 proficiency. In 1979, Cummins asked the question of the dependence of bilingualism on a very 
well developed first language: it is called the interdependence hypothesis. Lasagabaster (2001) in his study confirmed the effects of the L1 knowledge on L2 writing, reading and grammar. In addition to the interdependence hypothesis, the Language Threshold Hypothesis argues that students must first attain an acceptable level of proficiency in the L2 before they can use their L1 reading skills (Grabe, 2008, p. 248). For writing, the L2 threshold has not been extensively explored. Grabe (2008) mentions two studies dating back to the 1990s: Johns and Mayes (1990), and Sasaki and Hirose (1996). In the first one, students who had better L2 proficiency wrote better summaries, and in the second one, L2 proficiency represented 52\% of the "variance with an L2 writing task" (Grabe, 2008, p. 248). Llach and Pilar (2010) also examined "The role of L2 proficiency in L2 reading-writing relationships", which is also the title of their article and found out that there was a significant correlation between reading and writing for low-mid level learners, whereas for the low-level learners the results were not significant. Fukuda (2011), who tested Japanese learners of English found "a positive correlation between L2 reading and writing skills", and L2 proficiency showed influence on L2 reading and writing skills (p. 371). Also, writing skills were more easily transferable from the L1 to the L2 than reading skills, contradicting Carson et al.'s study of 1990 (p. 371). In addition, as the students had had a writing course before in the L1, that study showed that L1 and L2 writing skills were linked. In sum, the L1 may influence L2 reading and writing, and the level of L2 proficiency is also crucial in the development of reading and writing skills. These studies illustrated the relationships between reading and writing in the $\mathrm{L} 1$ and the $\mathrm{L} 2$, but what about reading in the $\mathrm{L} 1$ and reading for translation? In 1993, Shreve et al. asked that question, and made the analogy between reading for comprehension and reading for translation. When translators read a source text in order to be able to translate it, they spend more time reading, focusing on linguistic problems. Reading for 
translation is part of the translation process. As Hatim and Mason (1990) mentioned, "translators are "privileged readers""; they read to produce, and they decode the source text in order to reencode (p. 224). In that sense, the text has to be well comprehended or analyzed. For example, Washbourne (2012) proposes reading methods for translation trainees such as reading tasks with reading briefs and goals, mind maps, and summary translation tasks (p. 48). Reading for translation is often not accounted for, and according to Shreve et al., some non-professional translators who were surveyed expressed that they actually did not read the text before starting to translate (1993, p. 24). As can be noticed in the following table, reading for comprehension and reading for translation are very similar tasks.

Table 21 Similarities: Reading for Comprehension and Reading for Translation

Reading for comprehension $\quad$ Reading for translation

\begin{tabular}{cc}
\hline Text analysis & Text analysis \\
\hline Know about genre & Know about the subject matter \\
\hline Extract information to agree or disagree & $\begin{array}{c}\text { Extract information for linguistic, and cultural } \\
\text { purposes }\end{array}$ \\
\hline Metaknowledge (including self-monitoring) & Metacognitive monitoring \\
\hline Draw conclusions (interpretation) & Draw conclusions (interpretation) \\
\hline
\end{tabular}

If reading and writing are closely linked and reading for translation can help complete reading for comprehension, it will also help develop writing skills. Shreve et al. (1993) state: "Reading and translating are but two of several types of language processing, including speaking, listening, writing, interpreting, paraphrasing and summarizing” (p. 23). All those language processes are intertwined (see Figure 6). 
Figure 6 Intertwined Language Processing Types

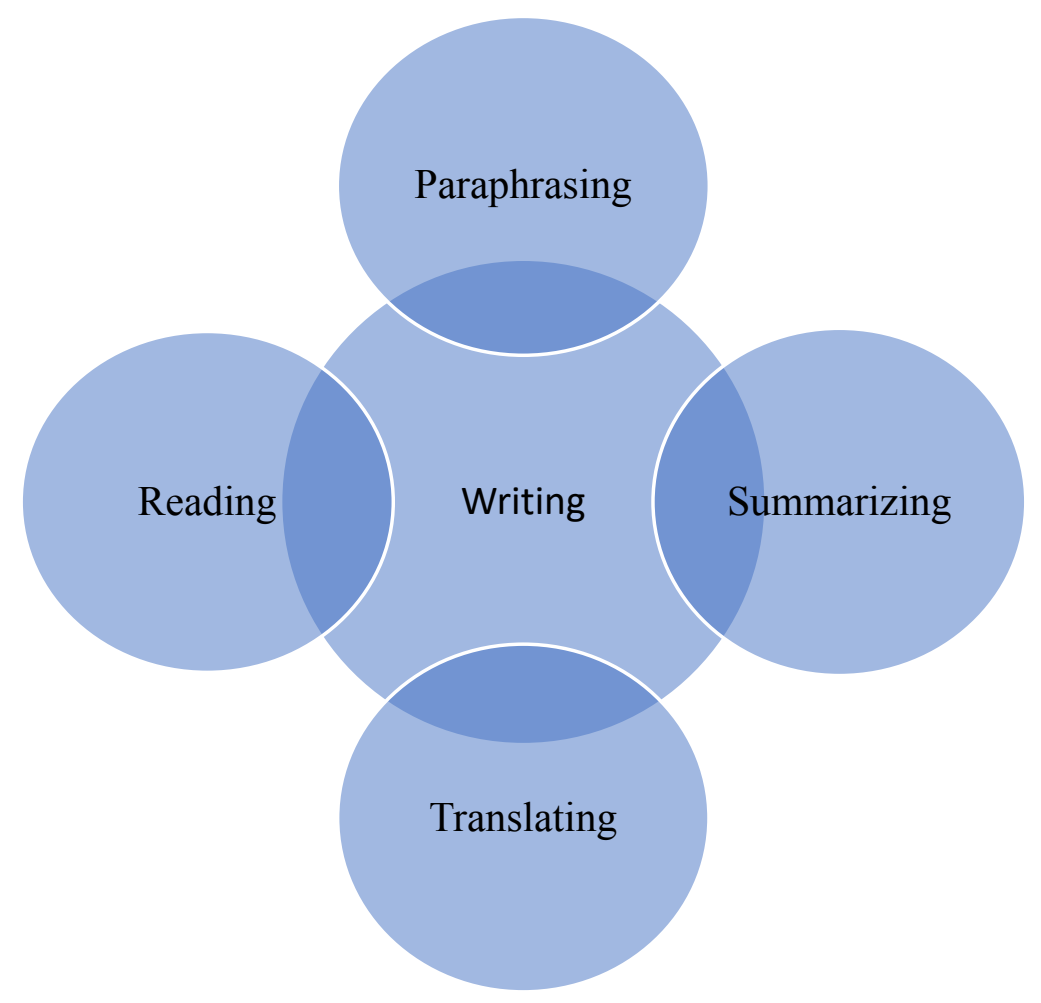

For instance, writing summaries develops reading comprehension (Graham, 2010). Paraphrasing can be used in reading and writing, and also in translation. It is good practice to have translation trainees paraphrase the source text, for example, as it helps comprehension, focuses on ideas rather than the literal textuality, and develops mental abilities. Translation Studies, Second Language Writing, and Second Language Reading are overlapping (see figure 7 below). In the same way, if translation can help improve reading and writing skills in the L2, in that sense, reading and writing may also be improved in the L1. Translation can also contribute to creative writing, as the two disciplines are closely linked. Students in our study wrote expository essays that can also be considered as creative writing. Casey Clabough (2014) in his guide to creative writing argues that even if an expository essay includes examples and analysis of cause and effect, it is still a form of art. It is thus not easy to give a definition of creative 
writing, as it involves subjectivity and emotion; it can be poetry, drama, or fiction, but even academic writing could be considered to belong under that umbrella term (Dev, Marwah \& Pal, 2008).

\section{Relationship between translation and creative writing: translators are writers.}

In a 2005 interview about translation and creative writing, Margaret Rogers, professor emerita at the University of Surrey in the United Kingdom, mentioned that in general, what is considered as creative writing in translation is rather literary translation, whereas specialized translation is perceived as not having any special label. She declares that translation is a "type of writing", "translators are writers", and as translation, creative writing is writing with a particular purpose in mind (Rogers, 2005) (see Figure 7 for a display of sub-competences common to both disciplines).

Manuela Perteghella, in her book chapter "Translation as Creative Writing” (2013) expresses creative writing as the translation of thoughts and inner voice into words. That kind of translation, which is an "imaginative" and "performative" process, is essential to the production of literary works. The text that writers produce is the product of linguistic and stylistic constraints, cultural and personal choices, and is then received and decoded by the reader and indefinitely reinterpreted (p. 196). In interlingual translation (as opposed to translating thoughts into words), writers have to not only deal with their own language, but also other languages, which means they need to pay attention to other voices.

In the $19^{\text {th }}$ and $20^{\text {th }}$ centuries, as travel and trade developed, translation enabled the discovery of new writers and their work and also new ways of writing (Bassnett, 2006, p. 174). In that sense, sometimes writers decide to translate works from other writers because they would have liked to write those themselves: "Translation is not just an exercise in such cases, it is part 
of the continuum of a writer's life" (Bassnett \& Bush, 2006, p. 175). Another form of translation in creative writing is code-switching and code mixing. That form of translation is very particular. The example of African Creative Writing given by Paul Bandia (1996) reflects the different hats a writer can wear. Bandia argues that African writers use code switching and code mixing to embellish their writing, and they are translators in that sense because they try to capture aspects "of African oral tradition in European languages" (1996, p. 151). As for the process research on translating and writing, Risku et al. interviewed a translator on her writing and translating processes, compared the processes of these two disciplines and concluded there were many similarities, but their study also revealed differences for text production: organization and content planning were more important for writing than for translating (2016, p. 64).

Figure 7 Diagram showing the links between the sub competences of translation and second language writing

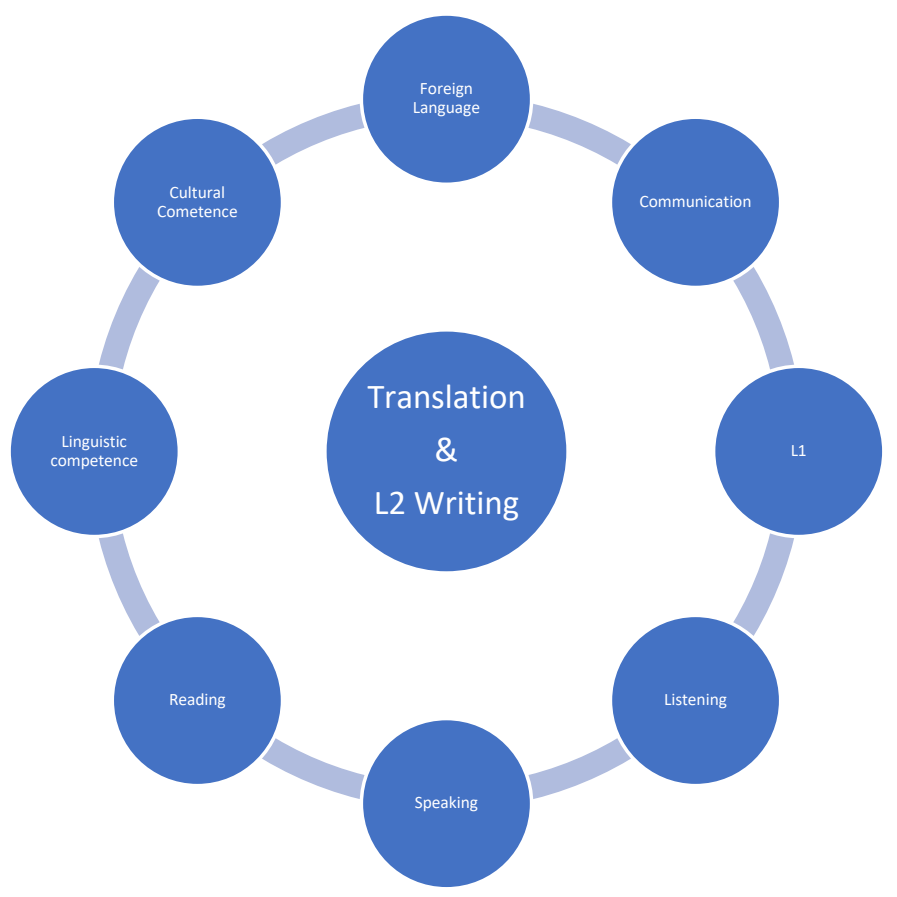




\section{Process research and corpus studies.}

Two other tools that can bring translation and second language writing together and help improve students' naturalness in writing are process-oriented teaching and the use of corpora. Process research enables students to improve their mental activity; it is learner centered and pushes students to solve issues. There are several approaches that can be used in class in a foreign language writing course, as well as in the translation course. An example would be diaries and in-class discussions (Fox, 2000, p. 128). The use of corpora in process-oriented teaching has been used in language learning and in translation: such an approach with such tasks improves learners' autonomy as they give students a means to correct their errors (O'Sullivan, 2007). It is of importance also to develop learners' learning and thinking strategies as well as their domain knowledge. O'Sullivan (2007) warns us about emotional aspects of learning, though, as not all students are disposed to take charge of their own learning.

As was discussed earlier, the knowledge acquired in the L1 can influence the knowledge acquired in the L2, and a lack in rhetorical structures in the L1 that is linked to sociocultural contexts might transpire in students' L2 writing (Myles, 2002). Cognitive modeling and especially cognitive modeling of what experts do can be used to help novice writers know which strategies to use (Kern, 2000, p. 182). Corpora use in foreign language writing and translation can actually help students learn about expert behavior. Some translation patterns or strategies can be extracted from parallel corpora (source texts and their translation), for example (Laviosa, 2002). Federico Zanettin (2013) proposed corpus-based translation activities for language learners to provide an additional resource to the traditional dictionary look-up and grammar rules. Students used corpora to analyze a machine translation and discuss their findings. Students who were able to use and analyze well different corpora resources did better in the ESL class 
studied. In composition, concordance search and collocation search have been used to measure differences between native speakers and second language writers (Laufer and Waldman, 2011). Laufer et al. (2011) investigated how native speakers of Hebrew used verb-noun collocations in their English writing. Their use of collocations was compared to that of native speakers and other learners of different proficiencies. The number of collocations used increased at an advanced level for the learners, but intralingual errors were still present.

\section{Interpreting.}

Of course, reading and writing are not the only skills involved//targeted in the acquisition of a language. There are four skills, and the ones still missing in this conversation are speaking and listening. For those two, which are oral skills, Translation Studies could also improve students' performance in the foreign language (see Figure 8 for Translation Studies' subcompetences). As translation strategies improve students' L2 writing, interpreting skills and strategies might improve learners' speaking and listening skills. For instance, Biasetti (2016) analyzed the impact of a Spanish interpreting course on "students' language, cultural, subject, and overall transfer competencies" (p. 615). When she designed her introductory interpreting course for intermediate Spanish students, she focused on consecutive, simultaneous interpreting, and sight translation. Biasetti made an important point of focusing rather on translator competence instead of translation competence, reminding us that, in Kiraly's words (2000), it "involves joining a number of new communities such as the group of educated users of several languages, those conversant in specialized technical fields, and proficient users of traditional tools and new technologies for professional interlingual communication purposes" (p. 13). That

quote stresses how today's translators' need to be versatile, and open to the world. Indeed, the image that one can have of translators in front of their white page, or their typewriter, isolated 
from everything and everyone else, is long gone. The same is true for a writer or a speaker. In her class, Biasetti used several interpreting activities, such as shadowing (repetition of heard text), chunking, paraphrasing, and restructuring. She concluded that the course was beneficial in reinforcing students' language, cultural, subject, and transfer competencies; they also experienced a sense of the profession. Hamada (2016), introduced shadowing in a class of learners of English in Japan, and concluded that such a method could be used in combination with other teaching techniques towards an improvement of L2 listening proficiency (p. 151).

Figure 8 Venn Diagram representing Translation Studies and its sub-competences

$$
\begin{gathered}
\text { Translation Studies } \\
\text { (translation/interpreting) }
\end{gathered}
$$
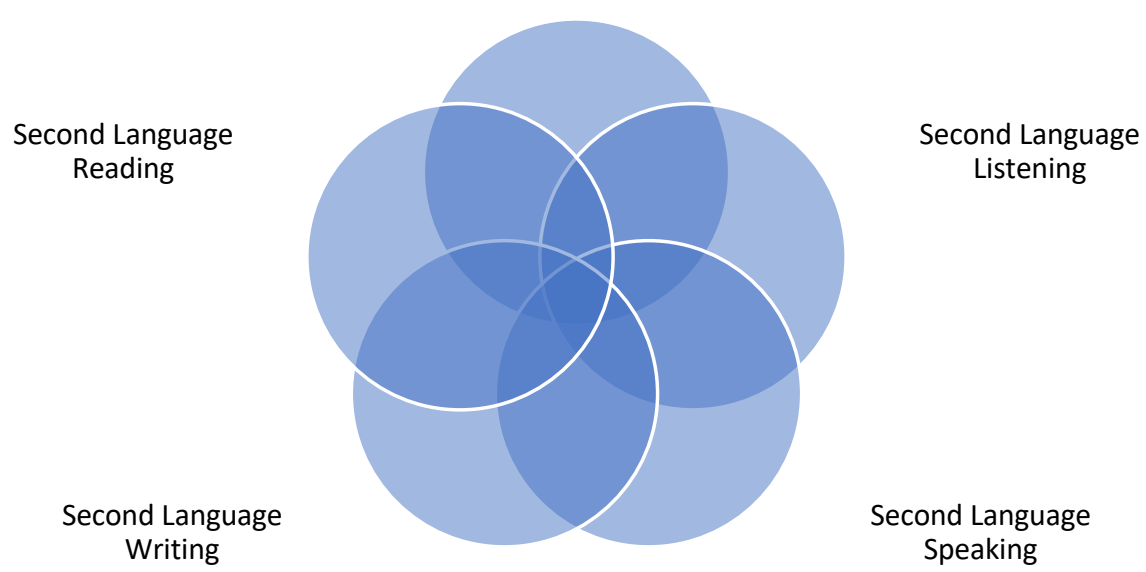


\section{Limitations of this Study}

This study has a few limitations, such as the number of participants. Eight participants per group is not much; more could certainly help obtain more robust results. Also, the participants came from different backgrounds, a variable that could not be controlled. As in any study, individual differences may also have an impact on how participants performed. As regards the teaching methods used in each class, all three were different. Especially in the Fall 2014 class, no translation activity was introduced, but rather grammatical exercises that consisted of recognizing errors in inauthentic sentences. Moreover, the treatments or writings used in the experimental class and in the two other control classes were not the same: data was gathered from summaries in the experimental class, and from compositions in the control classes. The novel read in class was from 1886, and some of its French is obsolete now. The use of the French dialect Breton is also misleading in the novel for students who read it. Actually, what is even more misleading even for a native speaker of French who is not from Brittany, are some French expressions that might be used in Brittany, but not in other parts of France. The distinction between the chronological and geographical dimensions of the French used in the novel are not easy to make for a native speaker, let alone for learners of French. Students have a tendency to mimic what they read, and even if the pedagogical purpose might be expose the students to French from the nineteenth century, this novel, which is read throughout the whole semester, is a distraction to the students' acquisition of contemporaneous French language production skills, as their level of French is not advanced enough to make the distinction between French from the nineteenth century, and contemporary French — and obviously also students cannot determine which French expressions are rather specific to Brittany. Given the students' level in French when they enter the French Composition class, such a novel might rather be introduced later on 
in the curriculum. For example, Hyland (2011, p. 32) suggests that in addition to literary texts, several models of writing should be taken into account while teaching writing, and teachers should concentrate on finding texts that will have a purpose outside of the classroom, such as recipes, business texts (reports), emails, blogs, news stories, and technical instructions. There was no significant difference before and after for lexical/grammatical choice, deviant sentences, and natural sentences in the Fall 2014 class, but it is important to note that even if translation strategies and translation activities were not introduced in that class, students still improved their writing, as feedback was provided to them, and they were able to turn in a corrected version of their compositions.

Another limitation would be the concordance search that was performed to confirm that the natural sentences found sounded natural, as it gave results about a word, usually a verb, to see if at least one instance in the online corpus matches the natural sentence studied. This technique limits verification to the word level and sentence level; this study focused on naturalness in text but concentrating on the text component only was that was hard to achieve. The native speaker check was helpful to counterbalance the concordance search, but then again, depending on the level of education or which French speaking region a native speaker comes from, the results about naturalness might be different: for example, a person who comes from Paris and a person who is from the south of France will not have the same perception on which sentences sound natural or not. Also, a native speaker living who has been living in the United Sates for a while might have a different perspective about how natural a sentence can sound. Vivian Cook (2008) raised the question of knowing if the L2 influences the L1 in that sense (p. 20). The sociocultural and affective environment in which the students were living while writing might also have affected the way they wrote. Students' mindset about writing in general might be 
worth considering, as some of them might be reluctant writers, even in their L1, or they have had a bad experience in a former writing class, for example. Apparently, multilingual writers can be better comprehended while focusing on multicompetences ("knowledge of two language in one mind" and how they influence each other, Cook, V., 2008, p. 17), genre, and identity, rather than concentrating on the L1 vs. L2 differences (Kobayashi and Rinnert, 2013).

As an extension of the task of writing a summary of the novel, in the experimental class (Spring 2016), students were asked to reflect on their work. They recorded their answers, but even if they received directions and were taught how to reflect, it was very difficult for them to have a critical point of view on what they wrote. Students were lacking self-editing skills, as well as self-reflection skills. They were able to fix a mistake when it was pointed out to them but were not able to find mistakes themselves. Students certainly needed more practice to acquire skills enabling them to self-reflect. To reach the level of self-editing, students need to self-regulate, which is a state that is not easy to attain. Better levels of self-regulation are dependent on metacognition, but also on motivation (Kim, 2016). If students can project themselves in the future, and are confident, it will help them develop self-efficacy (capacity to achieve certain goals). Norman and Aron (2003) in their study explored that concept of future self, and they concluded that the levels of availability and of accessibility of that self, and the perceived control over a possible self, act on the motivation an individual has for that possible self (p. 505). In our Spring 2016 course, the researcher also noticed that as the class was very demanding, it was hard for students to commit to assignments they were not used to.

One might also question the importance of naturalness in translation nowadays given the rise of foreignization (elements of the source text being present in the target text). Foreignization and domestication are dependent on text genre. Domestication is usually chosen for technical 
texts. Margaret Rogers (1999, p.24) also argues that for non-native speakers of the TL, it is better to translate informative texts rather than expressive or persuasive ones. However, who should translate what remains debatable depending on the purpose of the translation. One can be reminded that levels of naturalness and non-naturalness acceptance are also mostly subjective. Laufer et al. (2011) point out the fact that "the use of incorrect collocations makes people sound odd but does not impair communication altogether" (p. 666). Another issue nowadays is English for Research Publication Purposes (ERPP) (Flowerdew, 2015): for many scholars and researchers in the world (the majority), English is not their first language, and sometimes some of them do not know English, which can deprive them from accessing some valuable information. In addition, English native speakers might choose to publish writings coming from other English native speakers more easily for quality purposes than coming from speakers for whom English is their second language (p. 252). Hyland (2016) does not agree though, and argues that non-native speakers of English publish nowadays more than ever before, and that for both, native and non-native speakers of English, it is difficult to publish, as both have to adapt their literacy skills for this specific purpose of publishing and where "rhetorical knowledge, persistence, and an awareness of an authorial self” are more important than grammatical accuracy (p. 67).

\section{Recommendations for Further Research}

This study could be run again in a French composition class with more participants, perhaps at a higher level of French, graduate students, for instance. With around twenty participants per group, the results might be different, and there might be a main effect for group, and there might be an interaction effect between group and time. The new groups used could 
actually be the same participants belonging to one and only class, if the number of students in that class were higher, which would avoid the problem of participants coming from different backgrounds, and they would be tested at different points in time. Also, other translation strategies and more activities could be introduced in class, such as activities using corpus studies. Parallel corpora (corpora containing source texts and their translation in the foreign language) could be used so that students could not only better understand how the two languages function, but they could also acquire the sense of coherence and cohesion in texts. Studies including parallel corpora in language learning have already been done, in which corpus studies were revealed as beneficial (Bernardini, 2004). A larger project could follow a group of participants at a lower level of French throughout their French studies who would have been in contact with translation at an early stage of foreign language learning. The progress and performance of these students in the foreign language compared to other students in regular foreign languages classes would be worth investigating.

Moreover, an extension of this study could suggest good strategies for working with students to reflect on their writing and help them, through post-task interviews, to understand what they are doing exactly when they are writing. The cognitive input of such study could be helpful to understand students' writing process in the foreign language. Kim (2016), proposes strategies or metacognitive steps to help students improve their learning process in second language writing, such as: demands of the task, evaluation of one's own language skills, planning of the approach to be taken, monitoring of one's progress, and adjustment of one's strategies as needed (p. 31). She also focuses on learned attention in her syllabus, so that students are aware they will have to take into account what already happened to be able to pay attention in the future. Students could also keep journals in which they would write their reflections on their 
writing; that task should be monitored, though, as they might diverge from the instructions, and move easily off topic.

Naturalness in writing is hard to assess, and the means available are limited. However, to investigate participants' writing in the foreign language, Semantic Latent Analysis (LSA) could be used. LSA's goal is to explore texts to see if they are coherent. It extracts and shows relationships between words while using statistical computations. The website http://sa.colorado.edu/ from Colorado University at Boulder is a useful source providing information about how LSA works, but it also presents tools that can be used directly (without having to make any statistical calculations) to measure coherence in sentences of a text, for example, or explore similarities between texts. Those tools are of value for French, as there is the possibility of choosing a French corpus against which the researcher's texts can be compared. For students' writings in a French composition class, for instance, concentrating on how similar sentences are to each other within a same text to measure coherence might be of interest. Coherence and cohesion are both components of naturalness in text. Foltz (1998) found that the coherence of text measured by LSA correlated with readers' comprehension of those texts, so the comprehension of a text can be predicted by the measure of coherence of that text (pp. 26-27). Another tool that uses LSA as basis, is the TAACO tool developed by Kristopher Kyle (University of Hawaï at Manoa). This tool can help test cohesion in texts, which is of interest for developing this study. In the same way as with the tools provided by Colorado University at Boulder, it enables the researcher to see if texts are coherent or if there is a high degree of cohesion in the texts as a whole rather than at the sentence level only, as it offers different options: local cohesion (sentence level), global cohesion (paragraphs rather than sentences), and overall cohesion (entire text) (Crossley, Kyle, \& McNamara, 2016). Unfortunately, even though 
some features of the software can still enable one to find patterns within French texts (overlap indices might work well), TAACO works best with English texts, as it has been set up for them.

Figure 9 Screenshot of TAACO's Interface

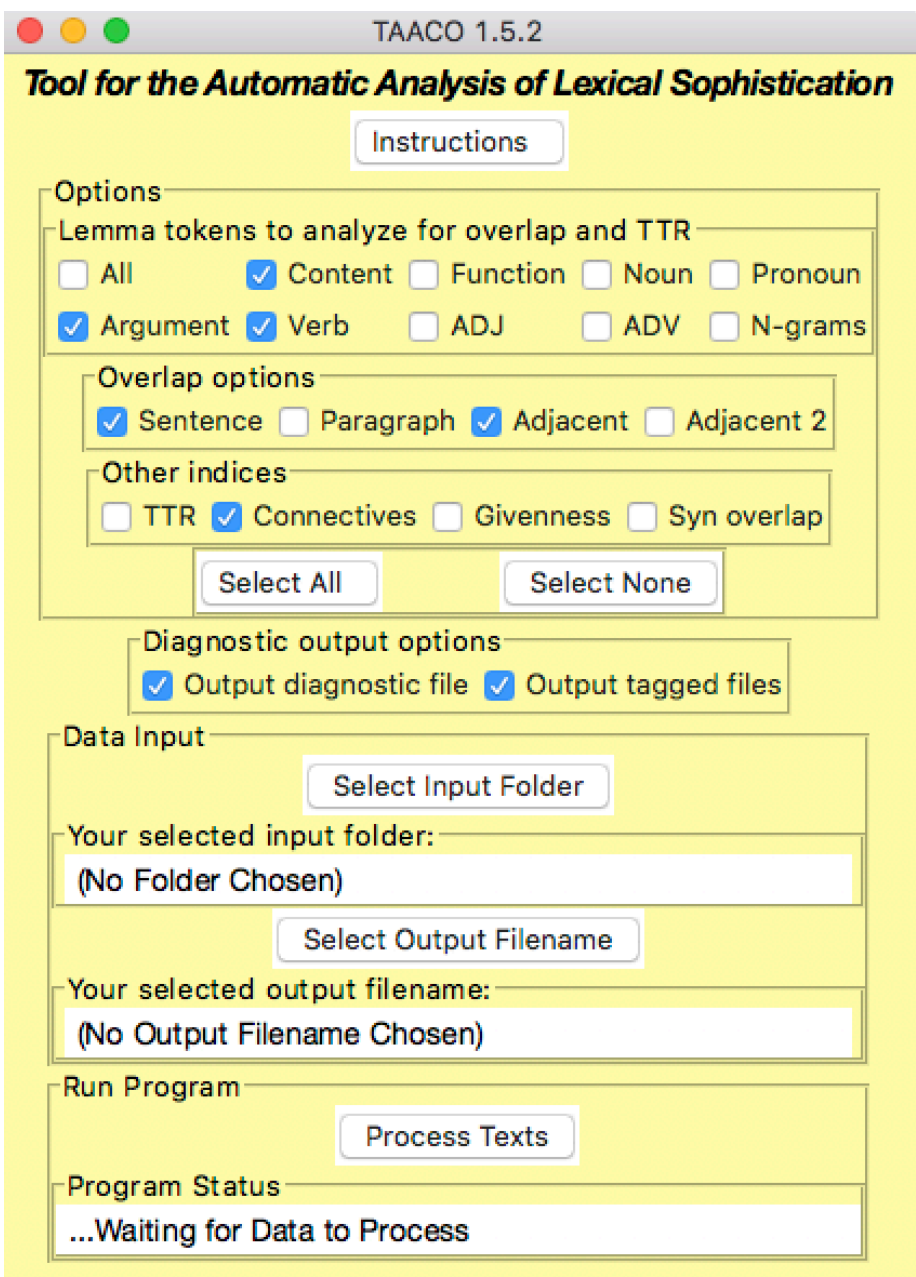

For instance, the features that are worth concentrating on in TAACO for French texts would be the Type-token ratio (TTR), which measures lexical diversity or vocabulary richness. The TTR score obtained is the result of dividing the number of unique lemmas in a text by the number of total lemmas. However, Richards and Malvern (2000) argue that the TTR depends on the length of texts: "larger samples of word tokens will give a lower TTR" (p. 2). They offer 
another tool also that enables to overcome that: vocd. In TAACO, the Adjacent Sentence overlap will show an average of the number of words repeated between sentences. The binary adjacent sentence overlap shows how many adjacent sentences have overlapping words. For the paragraph overlap, it is the same system as for sentences, except for paragraphs. For example, the adjacent paragraph overlap shows an average of number of words that are encountered between paragraphs and the binary two-paragraph overlap helps calculating how many neighboring paragraphs contain repeated items (Kyle, 2017, p. 3-9).

Investigating naturalness in translating into the second language, as second language writing and translating may involve the same cognitive processes could bring some insights not only about naturalness in L2 translating, but also L2 writing. Uzawa (1996) explored the characteristics of translation processes from L1 into the L2 and concluded that translation tasks are beneficial because learners pay more attention to the language they use during the translating process; the results of the interviews conducted revealed that students found translation more helpful than L2 writing tasks as they were more challenged during those tasks (p. 288). Having students translate into the L2 might improve their L2 language skills, and Posey (2009) affirms that the L2 translator has a better cultural competency, he is likely to understand the source text better, and is more conscientious with the target text (p. 46). Also, Vaezi (2007) explored the effects of translation from the L1 to the L2 on the use of correct grammatical structures. The results showed that the use of that translation practice was beneficial; it enabled students to achieve linguistic accuracy for specific structures, which would also help learners in the long run to communicate effectively and accurately in communicative situations. Even if Vaezi's study is of some value for translation and second language acquisition, the translation activities used with those participants were focused on grammar and not oriented towards an audience, and remind 
us of the grammar-translation method. As was already stated in this dissertation, translation is communication, and it can be used in a communicative setting in class. Translation activities do not need to be dry mechanical drills. From a technical perspective, there is evidence that students learn better when they write longhand compared to when they type (May, 2014). In that sense, investigating students' improvement in writing in a class where they handwrite their L2 essays might give different results than in our study in which students typed all their essays and summaries.

\section{Conclusion}

To conclude, in our study, subjects' written L2 text is a translation of the L1 text that is stored in their minds. The tendency shown in this study leads us to believe that translation, and especially translation strategies, are beneficial in the foreign language classroom. Translation studies, which is a discipline that borrows from many others such as linguistics, comparative literature, and composition studies, can also contribute to the pedagogical toolbox of other disciplines such as second language writing. Perhaps if Translation Studies were implemented early in the curriculum, students entering upper level second language writing classes could be equipped with the tools enabling them to be more prepared. Students today are not at the level they are supposed to be in a language when they leave college (Neuman, 2017). More research needs to be done on the links between the four language skills, and Translation Studies to help learners develop their competences. Translation Studies is a discipline in itself, but interdisciplinarity is of the essence, and instead of considering several disciplines separately such as second language writing, or second language reading, or translation, perhaps it is time to bring all of them together to provide a better curriculum for our students. 


\section{References}

Alegría De La Colina, A., \& Del Pilar García Mayo, M. (2009). Oral interaction in task-based EFL learning: The use of the L1 as a cognitive tool. IRAL - International Review of Applied Linguistics in Language Teaching, 47(3-4), 325-345. https://doi.org/10.1515/iral.2009.014

Alves, F., Pagano, A., \& Silva, I. (2009). A new window on orientation in the translation process: Mapping translators' metacognitive activity through the combined use of eye tracking data and retrospective protocols. In International Workshop on Translation Process research. Graz: University of Graz.

Arrojo, R. (1986). Oficina de Tradução: a Teoria na Prática. Sao Paolo: Editora Ática.

Atkinson, D. (1987). The mother tongue in the classroom: A neglected resource? ELT Journal, 41(4), 241-247.

Baker, M. (1995). Corpora in translation studies: An overview and some suggestions for future research. Target, 7(2), 223-243.

Baker, M. (2001). Routledge encyclopedia of translation studies. (M. Baker \& K. Malmkjær, Eds.). London and New York: Routledge

Bandia, P. (1996). Code-switching and code-mixing in African creative writing: some insights for translation studies. TTR : Traduction, Terminologie, Rédaction, 9(1), 139-153. https://doi.org/10.7202/037242ar

Bao, R., \& Du, X. (2015). Learners ' L1 use in a task-based classroom : learning Chinese as a foreign language from a sociocultural perspective. Journal of Language Teaching and Research, 6(1), 12-20. https://doi.org/10.17507/j1tr.0601.02 
Barkaoui, K. (2007). Teaching writing to second language learners : insights from theory and research. TESL Reporter, 40(1), 35-48.

Bassnett, S., \& Bush, P. R. (2006). The translator as writer. Continuum. Retrieved from https://books.google.com/books/about/The_Translator_as_Writer.html?id=7r0UPf8qeNwC

Bell, R. (2001). Psycholinguistic/cognitive approaches. In M. Baker (Ed.), Routledge encyclopedia of translation studies (pp. 185-190). Routledge.

Bernardini, S. (2004). Corpora in the classroom. In J. M. Sinclair (Ed.), How to use corpora in language teaching (pp. 15-36). John Benjamins. Retrieved from https://books.google.com/books?hl=en\&lr=\&id=2Fkhk8gChNsC\&oi=fnd\&pg=PT22\&ots= p1W8AcDZMX\&sig=VuWBfOGWDQYQOCEhCzttvC8Uww4\#v=onepage\&q\&f=false

Biasetti, G. (2016). Benefits of an interpretation course for foreign language learning and development. Hispania-a Journal Devoted to the Teaching of Spanish and Portuguese, 99(4), 615-634. https://doi.org/10.1353/hpn.2016.0107

Bogglesworld ESL Glossary http://bogglesworldesl.com/glossary/grammartranslationmethod.htm

Bot, K. De. (1992). Applied linguistics. Applied Linguistics, 13(1), 1-24. https://doi.org/10.1093/applin/13.1.1

Bowles, M. (2010). The think-aloud controversy in second language research (Second Lan). New York, USA and Oxon, UK: Routledge Taylor \& Francis. https://doi.org/10.1111/j.1540-4781.2011.01251.x

Brown, H. D. (2001). Teaching by principles: An interactive approach to language pedagogy (2nd ed.). New York: Addison Wesley Longman, Inc. 
Bryce, E. (2017). Afin que les coraux mangent moins de plastique, nous devons lui donner mauvais goût. Retrieved from http://www.anthropocenemagazine.org/2017/10/afin-que-lescoraux-mangent-moins-de-plastique-nous-devons-lui-donner-mauvais-gout/?lang=fr

Carré, B. (2015). L’odyssée christique. (P. Carré, Ed.). Lulu Press. Retrieved from https://books.google.com/books?id=TMzVCgAAQBAJ\&pg=PA21\&lpg=PA21\&dq=\%22lu mière+compactée\%22\&source=bl\&ots=6xxFW69X5S\&sig=QyyPvzivkhNja03DF8xXImG Mq28\&hl=en\&sa=X\&ved=0ahUKEwiG5O6y8P3ZAhVvUd8KHZ4CCuUQ6AEINDAD\#v $=$ onepage $\& \mathrm{q}=\% 22$ lumière compacté $\mathrm{\%} \% 22 \& \mathrm{f}=$ false

Carreres, A. (2006). Strange bedfellows: Translation and language teaching. Sixth symposium on translation, terminology and interpretation in cuba and canada, 1-21. Retrieved from http://cttic.org/ACTI/2006/papers/Carreres.pdf

Chang, S.-C. C. (2011). A contrastive study of grammar translation method and communicative approach in teaching english grammar. English Language Teaching, 4(2), 13-24.

\section{https://doi.org/10.5539/elt.v4n2p13}

Chardonnens, D. (1997). L'homme sous le regard de la providence. Paris: Librairie philosophique J. Vrin. Retrieved from https://books.google.com/books?id=M8DvOLBttU8C\&pg=PA7\&dq=\%22le+sens + plus + pr ofond $\% 22 \&$ hl $=$ en\&sa $=$ X\&ved=0ahUKEwjutoSm-v3ZAhUNnAKHf_TDmA4ChDoAQgmMAA\#v $=$ onepage $\& \mathrm{q}=\% 22$ le sens plus profond $\% 22 \& \mathrm{f}=$ false

Chesterman, A. (1997). Memes of translation: The spread of ideas in translation theory. Amsterdam: John Benjamins. Chesterman, A. (2000). Memetics and translation strategies. Retrieved from http://www.helsinki.fi/ chesterm/2000iMemetics.html 
Clabough, C. (2014) Idiot's Ggides: Creative writing. Retrieved from http://proquest.safaribooksonline.com/book/creativity/9781615645015

Conacher, J. E. (1996). Native speaker to native speaker: Crossing the translation gap. In Teaching translation in universities. Present and future perspectives (pp. 161-182). London: Association for French Language Studies \& Centre for Information on Language Teaching and Research.

Cook, G. (2007). A thing of the future: Translation in language learning: Viewpoint. International Journal of Applied Linguistics (Vol. 17). https://doi.org/10.1111/j.14734192.2007.00160.x

Cook, G. (2010). Translation in language teaching. OUP Oxford. Retrieved from https://books.google.com/books?id=bgEwAQAAMAAJ\&pgis=1

Cook, V. (2001). Using the first language in the classroom. The Canadian Modern Language Review, 57(3), 402-423. https://doi.org/10.3138/cmlr.57.3.402

Cook, V. (2008). Multi-competence: Black hole or wormhole for second language acquisition research? In Z. Han \& E. S. Park (Eds.), Understanding second language process (pp. 1626). Retrieved from https://books.google.com/books?hl=en\&lr=\&id=dQWjeq1 CYAC\&oi=fnd\&pg $=$ PA16\&dq $=$ Multicompetence:+Black+hole+or+wormhole+for + second + language + acquisition + research $\% 3 \mathrm{~F}$ \&ots=pTJ82ur4pb\&sig=6OXiJG-S4o9rqs_Bf8UEC5-ds_0\#v=onepage\&q=Multicompetence $\% 3 \mathrm{~A}$ Black hole or wo

Cook, V. (1991). Second language learning and language teaching. London: Edward Arnold. Copeland, R. (1991). Rhetoric, hermeneutics, and translation in the Middle Ages. New York: Cambridge University Press. 
Crossley, S. A., Kyle, K., \& McNamara, D. S. (2016). The tool for the automatic analysis of text cohesion (TAACO): Automatic assessment of local, global, and text cohesion. Behavior Research Methods, 48(4), 1227-1237. https://doi.org/10.3758/s13428-015-0651-7

Cumming, A. (2001). Learning to write in a second language : Two decades of research. International Journal of English Studies, 1(2), 1-23. https://doi.org/10.1007/978-1-44191428-6

Cumming, A. (1989). Writing expertise and second-language proficiency*. Language Learning, 39(1), 81-135. https://doi.org/10.1111/j.1467-1770.1989.tb00592.x

Cummins, J. (1979). Linguistic interdependence and the educational development of bilingual children. Review of Educational Research, Vol . 49 , No . 2 ( Spring , 1979 ), pp . 222-251 Published by : American Educational Research Associati, 49(2), 222-251.

Dev, A.N., Marwah, A., Pal, S. Creative writing. Retrieved from http://proquest.safaribooksonline.com/book/communications/writing/9788131719848

Dimitrova, Englund, B. (2005). Expertise and explicitation in the translation process. Amsterdam/Philadelphia: John Benjamins.

Drobner, H. (1999). Les pères de l'Eglise: sept siècles de littérature chrétienne. Fribourg-enBrisgau: Desclée.

Duff, A. (1989). Translation. Oxford: Oxford University Press.

Duran, L. (1994). Toward a better understanding of code switching and interlanguage in bilinguality: implications for bilingual instruction. The Journal of Educational Issues of Language Minority Students, 14(1986), 69-88.

Elbow, P. (1973). Writing without teachers. London: Oxford University Press. 
Elmayantie, C. (2015). The use of grammartransaltion method. Journal on English as a Foreign Language, 5(2), 125-132. Retrieved from http://e-journal.iainpalangkaraya.ac.id/index.php/jefl/article/view/372/620

Fink, E. (1976). Proximité et distance: essais et conférences phénoménologiques. Grenoble: Jérôme Millon. Retrieved from https://books.google.com/books?id=jSfJNDU0wMAC\&pg=PA61\&lpg=PA61\&dq=\%22le+ sens + plus + profond $\% 22 \&$ source $=$ bl\&ots $=8 \mathrm{j} Y 2 \mathrm{wKotft} \&$ sig $=$ hzr 1UPywb0S6HuBFytm3HAKdQ\&hl=en\&sa=X\&ved=0ahUKEwiChPH09P3ZAhVRON8KHQT5AY44ChDoAQgmMAA $\# \mathrm{v}=$ onepage $\& \mathrm{q}=\% 22$ le sens plus profond $\% 22 \& \mathrm{f}=$ fal

Fitzgerald, J. \& Shanahan, T. (2010). Reading and writing relations and their development. Educational Psychologist (October 2014), 37-41. https://doi.org/10.1207/S15326985EP3501

Flowerdew, J. (2015). Some thoughts on English for research publication purposes (ERPP) and related issues. Language Teaching, 48(2), 250-262. https://doi.org/10.1017/S0261444812000523

Fox, O. (2000). The use of translation diaries in a process-oriented translation teaching methodology. In C. Schäffner \& B. Adab (Eds.), Developing translation competence (pp. 115-130). Amsterdam \& Philadelphia: John Benjamins. Retrieved from https://books.google.com/books?hl=en\&lr=\&id=g1NjLIc2WUC\&oi=fnd\&pg=PA115\&dq=Process + oriented + teaching\&ots=Un2HHWDb43 $\&$ sig $=29$ alVulc5VVryi2PsBqavGW0g5U\#v=onepage \&q=Process oriented teaching $\& \mathrm{f}=$ false 
Frantzen, D. (1995). The effects of grammar supplementation on written accuracy in an intermediate Spanish content cours. Modern Language Journal, 79, 329-344.

Fukuda, E. (2011). Relationships of L1 and L2 reading and writing skills. The Bulletin of the Graduate School, Soka University, 33, 353-379.

Gatenby, E. V. (1967). Translation in the classroom. English Language Teaching, 2(8), 214-218. Gellerstam, M. (1986). Translationese in Swedish novels translated from English. In L. Wolli \& H. Lindquist (Eds.), Translation Studies in Scandinavia. Lund: CWK Gleerup.

Gentzler, E. (1998). Forword. In S. Bassnett \& A. Lefevere (Eds.), Constructing cultures essays on literary translation (pp. ix-xxii). Clevedon, Philadelphia, Toronto, Sydney, Johanesburg: Multilingual Matters.

Gerver, D. (1976). Empirical studies on simultaneous interpretation: A review and a model. In Translation: applications and research (pp. 165-207). New York: Gardner Press.

Gerver, D. (1974). Simultaneous listening and speaking and retention of prose. Quarterly Journal of Experimental Psychology, 26(3), 337-341. https://doi.org/10.1080/14640747408400422

Gilmore, A. (2009). Using online corpora to develop students' writing skills. ELT Journal, 63(4), 363-372. https://doi.org/10.1093/elt/ccn056

González Davies, M. (2014). Towards a plurilingual development paradigm: From spontaneous to informed use of translation in additional language learning. Interpreter and Translator Trainer, 8(1), 8-31. https://doi.org/10.1080/1750399X.2014.908555

Grabe, W. (2003). Reading and writing relations: Second language perspectives on research and practice. In B. Kroll (Ed.), Exploring the dynamics of second language writing. Retrieved from 
https://books.google.com/books?hl=en\&lr=\&id=vBTap8uUhcoC\&oi=fnd\&pg=PA242\&dq $=$ reading + improves + writing $\&$ ots $=3 \mathrm{KaFVIROCQ} \&$ sig $=-$ EQ3dQOQ9acUjWW27Qi6eQJAyK0\#v=onepage\&q=reading improves writing\&f=false Graham, S. and Hebert, M. (2010). Writing to read, 1-57. Retrieved from http://eric.ed.gov/ERICWebPortal/recordDetail?accno=ED254820

Gumperz, J. J. (1982). Discourse strategies. Cambridge: Cambridge University Press.

Hamada, Y. (2016). Teaching EFL learners shadowing for listening : Developing learners' bottom-up skills. Taylor and Francis. Retrieved from http://ebookcentral.proquest.com/lib/kentstate/detail.action?docID=4578983

Harriman-Smith, J. (2015). Une tragédie possible : Corinne, ou l'Italie et Roméo et Juliette. Études Françaises, 51(1), 125. https://doi.org/10.7202/1028525ar

Hatim, B. A. (2014). Teaching and researching translation. New York: Routledge Taylor \& Francis. Retrieved from https://books.google.com/books?id=1E5pAwAAQBAJ\&pg=PT119\&lpg=PT119\&dq=intrat extual + coherence \&source=bl\&ots $=$ OkCnWWWv2C\&sig=xQ0PIzIoAa5VkHwufYPUfTFL uA\&hl=en\&sa=X\&ved=0ahUKEwiHv4KLwovbAhWJ7IMKHUjhBksQ6AEIRDAE\#v=on epage $\& \mathrm{q}=$ intratextual coherence $\& \mathrm{f}=$ false

Hatim, B., \& Mason, I. (1990). Discourse and the translator. London and New York: Longman. Hayes, J. R., \& Chenowith, A. N. (2001). Fluency in writing. Written Communication, 19(1), $80-98$.

Hayes, J. R. (2006). New directions in writing theory. Handbook of Writing Research, 28-40. 
Hervey, S., \& Higgins, I. (1992). Thinking translation: A course in translation method: French to English. London and New York: Routledge.

Hervey, S., Higgins, I., \& Haywood, L. (2005). Thinking Spanish translation. A Course in translation method: Spanish to English. London and New York: Routledge.

Hönig, H. G., \& Kußmaul, P. (1982). Strategy of translation. A teaching and workbook. Tubingen: Gunter Narr Verlag.

Hsu, J. (2004). Reading, writing, and reading-writing in the second language classroom: A balanced curriculum, 34. Retrieved from http://search.proquest.com/docview/62060018?accountid=13042

Hyland, K. (2016). Academic publishing and the myth of linguistic injustice. Journal of Second Language Writing, 31, 58-69. https://doi.org/10.1016/j.jslw.2016.01.005

Hyland, K. (2011). Learning to write issues in theory, research, and pedagogy. In R. Manchon (Ed.), Learning-to-write and writing-to-learn in an additional language (pp. 17-36). Amsterdam \& Philadelphia: John Benjamins. Retrieved from https://books.google.com/books?hl=en\&lr=\&id=AKINXPHz7OYC\&oi=fnd\&pg=PA17\&dq $=$ help + foreign + language + writers + write + better\&ots $=H X h k v 8 g 9 V p \& s i g=H A q 4 i r Z c m y o C S$ $2 \mathrm{ZPIHb0rfwTKXs} \# \mathrm{v}=$ onepage $\& \mathrm{q}=$ help foreign language writers write better $\& \mathrm{f}=\mathrm{false}$ Ishikawa, S. (1995). Objective measurement of low-proficiency EFL narrative writing. Second Language Writing, 4, 51-70.

Jääskeläinen, R. (2010). Looking for a working definition of 'translation strategies'. In I. M. Mees, F. Alves, \& S. Göpferich (Eds.), Methodology, technology and innovation in translation process research: A tribute to Arnt Lykke Jakobsen (pp. 319-336). 
Samfundslitteratur Press. Retrieved from http://www.bogide.dk/productsamples/9788759397572.pdf

Jack C. Richards; Theodore S. Rodgers. (2014). Approaches and methods in language teaching Jack C. Richards, Theodore S. Rodgers - Google Books (3rd ed.). Cambridge: Cambridge University Press. Retrieved from https://books.google.com/books?hl=en\&lr=\&id=HrhkAwAAQBAJ\&oi=fnd\&pg=PR1\&dq= grammar+translation + method + advantages + and + disadvantages\&ots=_KiEzq8ejb\&sig $=W v d$ 2LskdhCFRFvsOYTMbd2hptdU\#v=onepage \&q\&f=false

Jakobson, R. (1959). On linguistic aspects of translation. On Translation. Retrieved from http://www.stanford.edu/ eckert/PDF/jakobson.pdf

Kaiser-Cooke, M. (1994). Translatorial expetise - a cross-cultural phenomenon from an interdisciplinary perspective. In K. K. Mary Snell-Hornby, Franz Pöchhacker (Ed.), Translation studies: An interdiscipline (pp. 135-140). Amsterdam/Philadelphia: Benjamins. Retrieved from https://books.google.com/books?id=TCvB2DN6i9kC\&pg=PA136\&lpg=PA136\&dq=expert $\mathrm{s}+$ and + problem + solving + in + translation\&source $=$ bl\&ots $=$ eSUEyXk$2 v \&$ sig $=a D j L H 28 q N t y N \_y U P u a R \_H E W 7 \mathrm{kmc} \& h l=e n \& s a=X \& v e d=0$ ahUKEwifloeXgP3R AhVE1xQKHTZmDfIQ6AEIODAF\#v=onepage \&q=experts and probl

Károly, A. (2014). Translation in foreign language teaching: A case study from a functional perspective. Linguistics and Education, 25(1), 90-107. https://doi.org/10.1016/j.linged.2013.09.009

Katan, D. (2009). Translator training and intercultural competence. La Ricerca Nella Comunicazione Interlinguistica. Modelli Teorici E Metodologici, 282-301. 
Kearns, J. (2008). Strategies. In Routledge encyclopedia of translation studies (2nd rev. e, pp. 282-285). Routledge.

Kellogg, R. T. (1999). Components of working memory in text production. In M. Torrance \& G. C. Jeffery (Eds.), The cognitive demands of writing: Processing capacity and working memory in text production (pp. 42-61). Amsterdam: Amsterdam University Press.

Kenny, D. (1998). Corpora in translation studies. In M. Baker (Ed.), Routledge encyclopedia of translation studies (pp. 50-53). London and New York: Routledge.

Kern, R. (2000). Literacy and language teaching. Hong-Kong: Oxford University Press.

Kim, M. (2016). Writing about writing: Qualities of metacognitive L2 writing reflections. Second Language Studies, 34(2), 1-54.

Kiraly, D. (2000). A social constructivist approach to translator education: Empowerment from theory to practice. Manchester: St. Jérôme.

Kobayashi, H., \& Rinnert, C. (2013). L1/L2/L3 writing development: Longitudinal case study of a Japanese multicompetent writer. Journal of Second Language Writing, 22(1), 4-33. https://doi.org/10.1016/j.jslw.2012.11.001

Kobayashi, H., \& Rinnert, C. (1992). Effects of first language on second language writing: Translation versus direct composition*. Language Learning, 42(2), 183-209. https://doi.org/10.1111/j.1467-1770.1992.tb00707.x

Koskinen, K. (2001). Kathleen Davis . Deconstruction and translation theories explained. Antoine Berman Aujourd'hui, 14(2), 240-243.

Krings, H. P. (1986). Was in den Köpfen von Übersetzern vorgeht. Eine empirische Untersuchung zur Struktur des Übersetzungsprozesses an fortgeschrittenen Französischlernern. Tübingen: Narr. 
Krings, H. P. (1987). Translation problems and translation strategies of advanced German learners of French (L2). In J. House \& S. Blum-Kulka (Eds.), In Interlingual and Intercultural Communication (pp. 263-276). Tübingen: Narr.

Kupske, F. F. (2015). Second language pedagogy and translation : The role of learners 'ownlanguage and explicit instruction revisited, Brazilian English Language Teaching Journal (June), 51-65.

Kyle, K., \& Crossley, S. (2017). Quick start guide and user manual for TAACO 1.5. Retrieved from http://www.kristopherkyle.com/uploads/1/3/9/3/13935189/_taaco_1.5_user_manual_7-1617.pdf

Lado, R. (1964). Language teaching: A scientific approach. New York: McGraw-Hill.

Lasagabaster, D. (2001). The effect of knowledge About the L1 on foreign language skills and grammar. International Journal of Bilingual Education and Bilingualism, 4(5), 310-331. https://doi.org/10.1080/13670050108667735

Laufer, B., \& Waldman, T. (2011). Verb-noun collocations in second language writing: A corpus analysis of learners' English. Language Learning, 61(2), 647-672. https://doi.org/10.1111/j.1467-9922.2010.00621.x

Lavault, E. (1985). Fonctions de la traduction en didactique des langues. Paris: Didier érudition. Laviosa, S. (2002). Corpus-based translation studies: theory, findings, applications. Amsterdam and New York: Rodopi.

Leffa, V. (2012). Ensino de línguas: passado, presente e futuro. Revista de Estudos da Linguagem. Revista de Estudos Da Linguagem, 20(2), 389-411. 
Leonardi, V. (2011). Pedagogical translation as a naturally-occurring cognitive and linguistic activity in foreign language learning. Annali Online Di Littere - Ferrara, 1-2, 17-28.

Leonardi, V. (2010). The role of pedagogical translation in second language acquisition.Google Books. Bern: Peter Lang International Academic Publishers. Retrieved from https://books.google.com/books?hl=en\&lr=\&id=Zd8DcUFt_wsC\&oi=fnd\&pg=PA11\&dq= The + Role + of + Pedagogical + Translation + in + Second + Language + Acquisition + pdf $\&$ ots $=$ RXS 1olw7_C\&sig=cW0POfo95FettiGOoSQ9Zxk9VQ8\#v=onepage\&q\&f=false

Levy, C., \& Marek, P. (1999). Testing components of Kellogg's multicomponent model of working memory in writing: The role of the phonological loop. In The cognitive demands of writing: Processing capacity and working memory in text pro-duction (pp. 25-41).

Amsterdam: Amsterdam University Press.

Levý, J. (1989). Translation as a decision process. In A. Chesterman (Ed.), Readings in translation theory (2nd ed., pp. 37-52). Mouton de Gruyter.

Liao, P. (2006). EFL learners' beliefs about and strategy use of translation in English learning. RELC Journal, 37(2), 191-215. https://doi.org/10.1177/0033688206067428

Lifang, Z. (2008). Comparison of two writing processes : Direct versus translated composition 英 語寫作中英語構思法與漢語翻譯法對比研究, 4(1), 8-17.

Lörscher, W. (1991). Translation performance, translation process, and translation strategies: a psycholinguistic investigation. Tubingen: Gunter Narr Verlag.

Lörscher, W. (2002). A model for the analysis of translation processes within a framework of systemic linguistics. Cadernos de Tradução, 97-112. Retrieved from http://150.162.1.115/index.php/traducao/article/download/6146/5704 Loti, P. (1886). Pêcheur d'Islande. Paris. 
Loti, P. (1902). An Iceland fisherman (Jules Cambon, Trans.) (E.Gosse, Ed.). New York: P.F. Collier \& Son.

Mabule, D. R. (2015). What is this? Is it code switching, code mixing or language alternating? Journal of Educational and Social Research, 5(1), 339-350. https://doi.org/10.5901/jesr.2015.v5n1p339

Machida, S. (2011). Translation in teaching a foreign (second) language: A methodological perspective. Journal of Language Teaching and Research, 2(4), 740-746.

\section{https://doi.org/10.4304/jltr.2.4.740-746}

Macmillan Education ELT (Producer). (2012). Philip Kerr: The return of translation. Available from https://youtu.be/kk-DUsgaZ4o

Malmkjær, K. (1993). Who can make nice a better word than pretty? Collocation, translation, and psycholinguistics. In M. Baker, F. Gill, \& E. Tognini-Bonelli (Eds.), Text and technology: In honour of John Sinclair. Amsterdam \& Philadelphia: John Benjamins.

Malmkjaer, K. (ed. . (1998). Translation and language teaching language teaching and translation. (K. Malmkjaer, Ed.). Manchester: St. Jérôme.

Malmkjaer, K. (1998). Love thy neighbour: will parallel corpora endear linguists to translators? Meta: Journal Des Traducteurs, 43(4), 534. https://doi.org/10.7202/003545ar

Marinai, E., Peters, C., \& Picchi, E. (1992). Bilingual reference corpora: Creation, querying, applications. In F. Kiefer, G. Kiss, \& J. Pajzs (Eds.), Papers in Computational Lexicography Complex '92. Budapest: Linguistics Institute, Hungarian Academy of Sciences. 
May, C. (2014). A learning secret: don't take notes with a laptop. Retrieved from https://www.scientificamerican.com/article/a-learning-secret-don-t-take-notes-with-alaptop/

McCarthy, M. J. (2015). The role of corpus research in the design of advanced-level grammar instruction. In Teaching and learning English grammar: Research findings and future directions (pp. 87-101). New York and London: Routledge. Retrieved from https://books.google.com/books?id=j17rBgAAQBAJ\&pg=PA98\&lpg=PA98\&dq=mccarthy + preferred + sequences $\&$ source $=$ bl\&ots $=$ mXr5sYgDi3\&sig=bFGYPMt2uIdE3Qap8ZchBn6 YTDk\&hl=en\&sa=X\&ved=0ahUKEwjXsvaG97jRAhWCL8AKHXIPBMUQ6AEIKjAD\#v $=$ onepage $\& \mathrm{q}=$ mccarthy preferred sequences $\& \mathrm{f}=\mathrm{fa}$

McLaughlin, B., Rossman, T., \& Beverly, M. (1983). Second language learning: an informationprocessing perspective. Language Learning, 33(2), 135-158.

Mogahed, M. (2011). To use or not to use translation in language teaching. Retrieved from http://translationjournal.net/journal/58education.htm

Moser, B. (1978). Simultaneous interpretation: A hypothetical model and its practical application. In D. Gerver \& H. W. Sinaiko (Eds.), Language interpretation and communication (pp. 353-368). New York: Plenum Press.

Munday, J. (2001). Introducing translation studies: Theories and applications. New York: Routledge.

Mure Latour, L. (1828). Triomphe de l'amour sur le fanatisme et le matérialisme. Paris, London; Munich, Brussels, Lausanne. Retrieved from https://books.google.com/books?id=IBgAAAAcAAJ\&pg=RA1-PA136\&lpg=RA1PA136\&dq=\%22lumière + compactée $\% 22 \&$ source=bl\&ots $=i$ STPMQsMNH\&sig=ixDjCscIi 
8vMRvgenhWyK0213wE\&hl=en\&sa=X\&ved=0ahUKEwiG5O6y8P3ZAhVvUd8KHZ4CC $\mathrm{uUQ6AEIKzAB} \# \mathrm{v}=$ onepage $\& \mathrm{q}=\% 22$ lumière compactée $\% 22 \& \mathrm{f}=\mathrm{fa}$

Murphy, A. C. (2002). Naturalness is to text what grammatical correctness is to sentences, 1-16. Retrieved from https://www.academia.edu/24689791/Naturalness_is_to_text_what_grammatical_correctnes s_is_to_sentences_a_corpus-driven_perspective

Myles, J. (2002). Second language writing and research : The writing process and error analysis in student texts. Tesl-Ej, 6(2), 1-19.

Nation, P. (2003). The role of the first language in foreign language learning. Indianaedu, (34), 1-8. https://doi.org/10.2307/327765

Neuman, R. (2017). Setting aside bureaucratic requirements. Retrieved from https://www.insidehighered.com/views/2017/05/18/undergraduate-foreign-languagerequirements-arent-particularly-effective-essay

Newson, D. (1998). Translation and foreign language teaching. In K. Malmkjær (Ed.), Translation and Language Teaching (pp. 63-68). Manchester, UK: St. Jérôme.

Nord, C. (1997). Translating as a purposeful activity: Functionalist approaches explained. Manchester: St. Jérôme.

Nord, C., \& Sparrow, P. (1991). Text analysis in translation : theory, methodology, and didactic application of a model for translation-oriented text analysis. Amsterdam - Atlanta: Rodopi. Retrieved from https://books.google.co.in/books?id=HaHTZ2IxIX4C\&pg=PR5\&source=gbs_selected_page $\mathrm{s} \& \mathrm{cad}=2 \# \mathrm{v}=$ onepage $\& \mathrm{q} \& \mathrm{f}=$ false 
Norman, C. C., \& Aron, A. (2003). Aspects of possible self that predict motivation to achieve or avoid it. Journal of Experimental Social Psychology, 39(5), 500-507.

https://doi.org/10.1016/S0022-1031(03)00029-5

Nunan, D. (1999). Second language teaching \& learning. Boston: Heinle \& Heinle Publishers.

O’Brien, S. (2006). Eye tracking and translation memory matches. Perspectives: Studies in Translatology, 14(3), 185-205.

O’Sullivan, Í. (2007). Enhancing a process-oriented approach to literacy and language learning: The role of corpus consultation literacy. ReCALL, 19(3), 269. https://doi.org/10.1017/S095834400700033X

Olmo-castillo, W. N. (2014). Teachers' attitudes towards code switching within a bilingual classroom.

Omura, Y. (1996). Role of translation in second language acquisition: Do learners automatically translate? (Unpublished doctoral thesis). University of Texas, USA.

Owen, C. (1988). Naturalness and the language learner. In M. McCarthy (Ed.), Naturalness in Language, English Language Research Journal (Vol. 2). Birmingham: University of Birmingham.

Owen, D. (2003). Where's the treason in translation? Humanising language teaching. Humanising Language Teaching, 5(1). Retrieved from http://www.hltmag.co.uk/jan03/mart1.htm

Pablo et al. (2011). Students and teachers' reasons for using the first language within the foreign language classroom (French and English) in Central Mexico. Profile, 13(2), 113-129. Retrieved from http://www.redalyc.org/articulo.oa?id=169222663009 
Paz, O. (1992). Translation: Literature and letters. In R. Schulte \& J. Biguenet (Eds.), Theories of translation. An anthology of essais from Dryden to Derrida (pp. 152-162).

Chicago/London: University of Chicago Press.

Perteghella, M. (2013). Translation as creative writing. In A companion to creative writing (pp. 195-212). Chichester, UK: John Wiley \& Sons, Ltd.

https://doi.org/10.1002/9781118325759.ch13

Llach, A., \& Pilar, M. (2010). Examining the role of L2 proficiency in L2 reading-writing relationships. Estudios Ingleses de La Universidad Complutense, 18.

Polio, C. (1997). Measures of linguistic accuracy in second language writing research. Language Learning, (March), 101-143. https://doi.org/10.1111/0023-8333.31997003

Popescu, T. (2013). Developing English linguistics students' translation competence through the language learning process. Procedia - Social and Behavioral Sciences, 93, 1075-1079. https://doi.org/10.1016/j.sbspro.2013.09.333

Posey, M. (2009). The advantages of L2 translation in the Cat in the Hat : A closer look at translation directionality. Letras, 46, 87-100.

Pym, A. (2014). Vinay and Darbelnet and the politics of translation solutions, (August), 1-14.

Raab, U. (1992). Stages and levels of the L2 writing process. (Unpublished master's thesis). Marburg University, Germany.

Randaccio, M. (2012). Translation and language teaching: translation as a useful teaching resource. In Aspetti del la didattica e del l'apprendimento del le lingue straniere: contribute de icollaboratori del Centro Linguistico del l'Università di Trieste (pp. 78-91). Trieste: EUT Edizioni Università di Trieste. 
Reiss, K. Vermeer, H. (2014). Towards a general theory of translational action. (C. Nord \& M. Dudenhofer, Eds.) (2nd ed.). London and New York: Routledge. Retrieved from http://samples.sainsburysebooks.co.uk/9781317640004_sample_573244.pdf

Richards, B., \& Malvern, D. (2000). Measuring vocabulary richness in teenage learners of French. In British Educational Research Association Conference, Cardiff University. Cardiff.

Risku, H., Milosevic, J., \& Pein-Weber, C. (2016). Writing vs. translating, (2016), 47-68. https://doi.org/10.1075/btl.128.03ris

Roca, J., Murphy, L., Marin, J., \& Ariel : (2002). A critical examination of L2 writing process research. In New directions for research in L2 Writing (pp. 11-47). Dordrecht; Boston: Kluwer Academic Publishers.

Rocha, J. (2010). Translation and perspective taking in the second language classroom. (Unpublished master's thesis). Kent State University, USA.

Rogers, M. (1999). Naturalness and translation. SYNAPS. Fagsprak, Kommunikasjon, Kulturkunnskap, 2(99), 9-31.

Rogers, M. (2005) Translation and creative writing: An interview with Professor Margaret Rogers. Interviewer: Ruzbeh Babaee. International Journal of Comparative Literature and Translation Studies http://www.journals.aiac.org.au/index.php/IJCLTS/article/view/2005

Russell, D. R., \& Yanez, A. (2003). Big picture people rarely become historians: Genre systems and the contradictions of general education. In Writing selves/ writing societies: Research from activity perspectives (pp. 331-362). 
Schäffner, C. (1998). Qualification for professional translators: translation in language teaching versus teaching translation? In Translation and Language Teaching: Language Teaching and Translation (Vol. 34, pp. 117-133). https://doi.org/10.1016/j.celrep.2011.1011.1001.7. Schulte, R. (2012). What is translation? Translation Review, 83(1), 1-4. https://doi.org/10.1080/07374836.2012.703119

Shiyab, S., \& Abdullateef, M. (2001). Translation and foreign language teaching. Lang. \& Transl., 13, 1-9.

Shreve, G. M., Schäffner, C., Danks, J. H., \& Griffin, J. (1993). Is there a special kind of "reading" for translation? An empirical investigation of reading in the translation process. Target: International Journal of Translation Studies, 5(1), 21-41. https://doi.org/10.1075/target.5.1.03shr

Shreve, G., \& Angelone, E. (2010). Translation and cognition. (G. Shreve \& E. Angelone, Eds.). Benjamins.

Sinclair, J. (1991). Corpus, concordance, collocation. Oxford University Press.

Sinclair, J. M. (1984). Naturalness in language. Ilha Do Desterro: A Journal of English Language, Literatures in English and Cultural Studies, 5(11), 45-55. Retrieved from http://www.journal.ufsc.br/index.php/desterro/article/viewArticle/9035

Singh, R. (1985). Grammatical constraints on code-switching: evidence from Hindi-English. Canadian Journal of Linguistics, 30, 33-45.

Snell-Hornby, M. (2006). The turns of translation studies. New paradigms or shifting viewpoints? Amsterdam \& Philadelphia: John Benjamins.

Steiner, G. (1975). After Babel : aspects of language and translation. New York: Oxford University Press. 
Swain.M, \& Lapkin, S. (2000). Task-based second language learning: the uses of the first language. Language Teaching Research, 4(3), 251-274.

Tarone, E., Downing, B., Cohen, A., Gillette, S., Murie, R., \& Dailey, B. (1993). The writing of Southeast Asian-American students in secondary school and university. Journal of Second Language Writing, 2, 149-172.

Thornbury, S. (2010). G is for grammar translation (blog). Retrieved from https://scotthornbury.wordpress.com/2010/10/15/g-is-for-grammar-translation/

Tirkkonen-Condit, S. (2010). Prototype definition of translation revisited. In B. LewandowskaTomaszczyk \& M. Thelen (Eds.), Meaning in Translation (pp. 217-230). Frankfurt am Main: Peter Lang International Academic Publishers. Retrieved from https://books.google.com/books?id=sQ_mkrzicCUC\&pg=PA220\&lpg=PA220\&dq=translat ion+does+not+communicate+preexistent + meaning $\&$ source $=$ bl\&ots $=$ OHBu2O0GUC\&sig=2sOe7CFMG311QuL6cisZvIOV VPk\&hl=en\&sa $=$ X\&ved=0ahUKEwiQzr2a6aDVAhUI9YMKHWAPCncQ6AEIPDAD\#v= onepage $\& \mathrm{q} \& \mathrm{f}=\mathrm{fals}$

Toury, G. (1995). Descriptive translation studies and beyond. Amsterdam: John Benjamins. Université Nice Sofia Antipolis. n.d. Learning and Teaching Foreign Languages. Grammar Translation. Retrieved from http://unt.unice.fr/uoh/learn_teach_FL/affiche_theorie.php?id_activite=102 Uzawa, K. (1996). Second language learners' processes of L1 writing, L2 writing, and translation from L1 into L2. Journal of Second Language Writing, 5(3), 271-294. https://doi.org/10.1016/S1060-3743(96)90005-3 
Vaezi, S., \& Mirzaei, M. (2007). The effect of using translation from L1 to L2 as a teaching technique on the improvement of EFL learners` linguistic accuracy-focus on form. Humanising Language Teaching, 9(5).

Varney, J. (2008). Deconstruction and translation : Positions, pertinence and the empowerment of the translator. Journal of Language \& Translation, (March), 113-131.

Vehmas, L. (2008). Translation studies: in search for vigour and relevance. Language and Globalization, (66), 35-70.

Venuti, L. (1998). Strategies of translation. In M. Baker (Ed.), Routledge encyclopedia of translation studies (pp. 240-244). London and New York: Routledge.

Vermeer, H. J. (1983). Aufsätze zur Translationstheorie. Heidelberg.

Vinay, J. P., \& Darbelnet, J. (1984). Stylistique comparée du français et de l'anglais (2nd ed.). Beauchemin Chenelière Education.

Vinay, J. P., \& Darbelnet, J. (1995). Comparative stylistics of French and English: A methodology for translation (11th ed.). Philadelphia: John Benjamins.

Washbourne, K. (2012). Active, strategic reading for translation trainees: Foundations for transactional methods. Translation and Interpreting, 4(1), 38-55.

Yasuda, S. (2011). Genre-based tasks in foreign language writing: Developing writers' genre awareness, linguistic knowledge, and writing competence. Journal of Second Language Writing, 20(2), 111-133. https://doi.org/10.1016/j.jslw.2011.03.001

Zanettin, F. (2013). Corpus methods for descriptive translation studies. Procedia-Social and Behavioral Sciences, 95, 20-32. https://doi.org/10.1016/j.sbspro.2013.10.618 
Zimmermann, R. (2000). L2 writing: Subprocesses, a model of formulating and empirical findings. Learning and Instruction, 10(1), 73-99. https://doi.org/10.1016/S09594752(99)00019-5 


\section{Appendix A}

\section{Questionnaire}

1. How long have you been studying French?

2. Have you been to a French speaking country? If yes, for how long?

3. How familiar are you with the French culture?

1 very familiar

2 familiar

3 a little familiar

4 not familiar

4. How do you make yourself familiar with the French culture?

5. Have you ever taken a writing class (like college writing)?

6. Have you heard about "translation" or "translation studies"?

7. What is translation for you? 
8. Rate your familiarity with translation:

1 very familiar

2 familiar

3 a little familiar

4 not familiar

9. Do you have any knowledge in translation (how it works)?

10. Have you ever taken a translation class? 


\section{Appendix B}

Calendar for French Composition and Composition Extended (French 33212/33214) - Fall

2014 prepared by the coordinator of the course

Webpage: http://www.personal.kent.edu/ rberrong/fr33212

Instructor: Carine Graff

Office: 307 D Satterfield

Office hours: Mondays and Wednesdays from 11 am to $12 \mathrm{pm}$.

Office phone: Please don't call. Send e-mail instead.

e-mail: cgraff2@kent.edu

\section{Calendar}

The professor reserves the right to make alterations in the calendar.

The text for the novel is available on the class website broken down into units for each class

(Lectures), and is accompanied by annotations that will make it easier to understand. Again, you

must print out the assigned reading for the day and bring it with you to class. No, showing up with your laptop is not an acceptable substitute for that, since you cannot make

annotations on the website. Do not, however, print out lectures more than a week in advance,

as I sometimes revise them.

I.

25.8: First day of class: explanation of the website and review of passé simple

27.8: Pêcheur d'Islande, Lecture 1

29.8: Lecture 2 
II.

1.9: Labor Day: no classes

3.9: Lecture 3

5.9: Lecture 4

7.9 Last day to withdraw without a grade of W; last day to add

III.

8.9: Lecture 5, plus Draft 1 of First essay (details below; remember the rules for written

assignments explained above: triple-spacing, etc.) On your zipdrive name the file [Your last

name]1-1

10.9: Lecture 6

12.9: Lecture 7, plus Draft 1 of First essay revised. Remember, you must hand in your first effort with my annotations on it as well. Name the file [Your last name]1-1r

IV.

15.9: Lecture 8

17.9: Lecture 9, plus Draft 2 of First essay (details below). Remember, you must turn in your previous drafts with my annotations on them with this draft. Name the file [Your last name]1-2

19.9: Lecture 10 
V.

22.9: Lecture 11, Victime du jour 20, plus Draft 2 of First essay revised. Remember, you must turn in your previous drafts with my annotations on them with this draft. Name the file [Your last name]1-2r

24.9: Lectures 12-13 Victime du jour 19

26.9: Lecture 14, plus Draft 3 of First essay (details below). Remember, you must turn in your previous drafts with my annotations on them with this draft. Name the file [Your last name]1-3

VI.

29.9: Lectures 15-16, Victime du jour 18, plus Review of grammar problems from Draft 3

1.10: Lecture 17, Victime du jour 17, plus Draft 3 of First essay revised. Remember, you must turn in your previous drafts with my annotations on them with this draft. Name the file [Your last name]1-3r

3.10: Lecture 18 Victime du jour 16

VII.

6.10: Lecture 19, Victime du jour 15, plus Draft 3a of First essay (see model under Composition on the class website). Remember, you must turn in your previous drafts with my annotations on them with this draft. Name the file [Your last name]1-3a 
8.10: Lectures 20-21, Victime du jour 14 plus Review of grammar problems from Draft 3a

10.10: Lecture 22, plus Draft 3a of First essay revised. Remember, you must turn in your previous drafts with my annotations on them with this draft. Name the file [Your last name]1-3ar

10-15 October: Faculty input midterm grades

VIII.

13.10: Hourly One on grammar and reading (Lectures 1-22)

15.10: Lectures 23-24, Victime du jour 13, plus Review of grammar problems from hourly

17.10: Lectures 25, plus Draft 4 of First essay. Remember, you must turn in your previous drafts with my annotations on them with this draft.Name the file [Your last name]1-4 IX.

20.10: Lecture 26, Victime du jour 12, plus Review of grammar problems from Draft 4 22.10: Lecture 27, Victime du jour 11, plus Draft 4 of First essay revised. Remember, you must turn in your previous drafts with my annotations on them with this draft. Name the file [Your last name]1-4r

24.10: Lecture 28 Victime du jour 10

X.

27.10: Lecture 29, Victime du jour 9, plus Draft 5 of First essay. Remember, you must turn in your previous drafts with my annotations on them with this draft. Name the file [Your 
last name]1-5

29.10: Lectures 30-31 Victime du jour 8

31.10: Lecture 32, plus Draft 5 of First essay revised. This is your final version of the First

Essay. Remember, you must turn in all your drafts with my annotations on them with this

final version. Name the file [Your last name]1final

\subsection{1: Last day to withdraw}

XI.

3.11: Lecture 33 Victime du jour 7

5.11: Lecture 34, Victime du jour 6, plus Draft 1 of Second Essay (topic below). Name the

file [Your last name]2-1

Once you get Draft 1 back from me with corrections and comments on it, you want to incorporate those corrections into your computer file promptly and expand it into Draft 2, which only takes a few minutes; all you have to do is arrange your six best examples in three categories and write the topic sentences for each category. Then print out Draft 2 and proof-read it on paper (no one can catch all his/her mistakes by proof-reading on a computer screen). In the days to come, and not the night before the paper is due much less that morning, work up Draft 3, etc., working on this some each day, and proof-reading each draft after you print it out on the printout. If you don't proof-read it draft by draft on the printout and incorporate your corrections as you move on to each new draft, you will never catch all your mistakes. Yes, I 
know, some of you will ignore this advice and leave everything until the morning the paper is due anyway, but at least you' ve been warned. To encourage you to follow my directions, however - and they will help you get a better grade - if I don't see signs of proof-reading as of

Draft 3a, your grade will be lowered.

7.11: Lecture 35 Victime du jour 5

XII.

10.11: Veterans' Day. No class.

12.11: Lecture 36 Victime du jour 4

14.11: Lecture 37 Victime du jour 3;

XIII.

17.11: Lectures 38-39 Victime du jour 2

19.11 Lectures 40-41, Victime du jour 1, plus completed Second Essay. Remember, you must turn in Drafts 1, 2, 3a, 4, and 5, printed out, which includes Draft 1 with my comments and corrections on it, with your completed essay. No credit for the essay without all 5 drafts. (See the comments above for how to do this.) On your zip drive you will just give me the final version, named [your name]2final.

21.11: reserved for snow days 
XIV.

24.11: Review

26.11: Review of grammar problems from Second Essay, plus Draft 1 of Third Essay (topic

blow). Name the file [Your last name] 3-1

26.11 [after noon]-30.11: Thanksgiving Vacation XV.

1.12: Hourly Two on grammar and reading (Lectures 23-41)

3.12: Review of grammar problems from second hourly

5.12: Review for final exam, plus completed Third Essay. Remember, you must turn in

Drafts 1, 2, 3a, 4, and 5, printed out, which includes Draft 1 with my comments and corrections on it, with your completed essay. No credit for the essay without all 5

drafts. (See the comments above for how to do this.) On your zip drive you will just give me the final version, named [your name]3final.

8.12: Comprehensive Final exam, part one, Monday 12:45-3:00 p.m.

10.12: Comprehensive Final exam, part two, Wednesday 10:15-12:30 


\section{Appendix C}

French Composition and Composition Extended (French 33212/33214) - Fall 2015

Webpage: http://www.personal.kent.edu/ rberrong/fr33212

Instructor: Carine Graff

Office: 307 D Satterfield

Office hours: Mondays and Wednesdays from $11 \mathrm{am}$ to $12 \mathrm{pm}$, and by appointment. Office hours will be held in the Moulton Hall lobby on the first floor.

Office phone: Please don't call. Send e-mail instead.

e-mail: cgraff2@kent.edu

Texts

Pierre Loti, Pêcheur d'Islande, available on the class webpage Any good grammar review

A large bi-lingual dictionary. This is essential to passing this course. If you can put your dictionary in your purse, it's too small to get you through this course. (This goes for the women in the class, too;)You will need a LARGE dictionary that has examples of usage. Do not rely on an on-line dictionary. Students who have done so have not done well in this class.

You will also need a zip drive, which you will turn in to me with assignments. Make sure to put your last name on the drive in some fashion that won't come off. 
Calendar

I.

31.8: First day of class: explanation of the website and review of passé simple

2.9: Pêcheur d'Islande, Lecture 1

4.9: Lecture 2

II.

7.9: Labor Day: no classes

9.9: Lecture 3

11.9: Lecture 4

\subsection{Last day to withdraw without a grade of $\mathrm{W}$; last day to add}

III.

14.9: Lecture 5, plus Draft 1 of First essay (details below; remember the rules for written assignments explained above: triple-spacing, etc.) On your zipdrive name the file [Your last name]1-1

16.9: Lecture 6

18.9: Lecture 7, plus Draft 1 of First essay revised. Remember, you must hand in your first effort with my annotations on it as well. Name the file [Your last name]1-1r

IV.

21.9: Lecture 8 
23.9: Lecture 9, plus Draft 2 of First essay (details below). Remember, you must turn in your previous drafts with my annotations on them with this draft. Name the file [Your last name]1-2 25.9: Lecture 10

V.

28.9: Lecture 11, Victime du jour 20, plus Draft 2 of First essay revised. Remember, you must turn in your previous drafts with my annotations on them with this draft. Name the file [Your last name]1-2r

30.9: Lectures 12-13 Victime du jour 19

2.10: Lecture 14, plus Draft 3 of First essay (details below). Remember, you must turn in your previous drafts with my annotations on them with this draft. Name the file [Your last name]1-3

VI.

5.10: Lectures 15-16, Victime du jour 18, plus Review of grammar problems from Draft 3

7.10: Lecture 17, Victime du jour 17, plus Draft 3 of First essay revised. Remember, you must turn in your previous drafts with my annotations on them with this draft. Name the file [Your last name]1-3r

9.10: Lecture 18 Victime du jour 16

VII.

12.10: Lecture 19, Victime du jour 15, plus Draft 3a of First essay (see model under Composition on the class website). Remember, you must turn in your previous drafts with my annotations on them with this draft. Name the file [Your last name]1-3a 
14.10: Lectures 20-21, Victime du jour 14 plus Review of grammar problems from Draft 3a 16.10: Lecture 22, plus Draft 3a of First essay revised. Remember, you must turn in your previous drafts with my annotations on them with this draft. Name the file [Your last name]1-3ar

10-15 October: Faculty input midterm grades

VIII.

19.10: Hourly One on grammar and reading (Lectures 1-22)

21.10: Lectures 23-24, Victime du jour 13, plus Review of grammar problems from hourly 23.10: Lectures 25, plus Draft 4 of First essay. Remember, you must turn in your previous drafts with my annotations on them with this draft. Name the file [Your last name]1-4

IX.

26.10: Lecture 26, Victime du jour 12, plus Review of grammar problems from Draft 4 28.10: Lecture 27, Victime du jour 11, plus Draft 4 of First essay revised. Remember, you must turn in your previous drafts with my annotations on them with this draft. Name the file [Your last name]1-4r

30.10: Lecture 28 Victime du jour 10

$\mathrm{X}$.

2.11: Lecture 29, Victime du jour 9, plus Draft 5 of First essay. Remember, you must turn in your previous drafts with my annotations on them with this draft. Name the file [Your last name]1-5

4.11: Lectures 30-31 Victime du jour 8 
6.11: Lecture 32, plus Draft 5 of First essay revised. This is your final version of the First Essay. Remember, you must turn in all your drafts with my annotations on them with this final version. Name the file [Your last name]1 final

\subsection{1: Last day to withdraw}

XI.

9.11: Lecture 33 Victime du jour 7

11.11: No class: Veterans' Day

13.11: Lecture 34, Victime du jour 6, plus Draft 1 of Second Essay (topic below). Name the file [Your last name]2-1

Once you get Draft 1 back from me with corrections and comments on it, you want to incorporate those corrections into your computer file promptly and expand it into Draft 2, which only takes a few minutes; all you have to do is arrange your six best examples in three categories and write the topic sentences for each category. Then print out Draft 2 and proof-read it on paper (no one can catch all his/her mistakes by proof-reading on a computer screen). In the days to come, and not the night before the paper is due much less that morning, work up Draft 3, etc., working on this some each day, and proof-reading each draft after you print it out on the printout. If you don't proof-read it draft by draft on the printout and incorporate your corrections as you move on to each new draft, you will never catch all your mistakes. Yes, I know, some of you will ignore this advice and leave everything until the morning the paper is due anyway, but at least you' ve been warned. To encourage you to follow my directions, however - and they will 
help you get a better grade - if I don't see signs of proof-reading as of Draft 3a, your grade will be lowered.

XII.

16.11: Lecture 35 Victime du jour 5

18.11: Lecture 36 Victime du jour 4

20.11: Lecture 37 Victime du jour 3;

XIII.

23.11: Lectures 38-39 Victime du jour 2

25.11 Lectures 40-41, Victime du jour 1, plus completed Second Essay. Remember, you must turn in Drafts 1, 2, 3a, 4, and 5, printed out, which includes Draft 1 with my comments and corrections on it, with your completed essay. No credit for the essay without all 5 drafts. (See the comments above for how to do this.) On your zip drive you will just give me the final version, named [your name]2final.

27.11: Thanksgiving Vacation: no class

XIV.

30.11: Review

2.12: Review of grammar problems from Second Essay, plus Draft 1 of Third Essay (topic blow). Name the file [Your last name] 3-1

4.12 Review for Hourly Two 
$\mathrm{XV}$.

7.12: Hourly Two on grammar and reading (Lectures 23-41)

9.12: Review of grammar problems from second hourly

11.12: Review for final exam, plus completed Third Essay. Remember, you must turn in Drafts 1, 2, 3a, 4, and 5, printed out, which includes Draft 1 with my comments and corrections on it, with your completed essay. No credit for the essay without all 5 drafts. (See the comments above for how to do this.) On your zip drive you will just give me the final version, named [your name]3final.

15.12: Comprehensive Final exam, part one, Tuesday, 10:15 a.m.-12:30 p.m.

18.12: Comprehensive Final exam, part two, Friday, 12:45-3:00 p.m.

(Lecture.paragraphe) in the text (1.2,

\section{ADDENDUM to the SYLLABUS (can be subject to changes)}

"Lectures" questions:

The answers to the "Lectures" questions will be handed in on a Word document, as hard copies in class.

Compositions and compositions drafts:

The drafts for the compositions and the compositions themselves will be submitted online in a Blackboard dropbox. 
You will turn in the drafts and the compositions on a triple spaced Word document. Set the language to French in Word.

This class requires regular work. You are responsible for reading the material, and submitting your work. If you feel lost, or if you need help, do not wait the last minute, come talk to me right away.

Sign and date this page and give it to your instructor by Friday of the first week of class, at the latest. Failure to do so will result in your being deregistered from the class, so don't forget. There are other students waiting in line to get into this class who would be happy to take your place.

I the undersigned do hereby acknowledge that I have received the syllabus for French 33212/4 and read it through to the beginning of the Calendar.

Signature:

Date: 


\section{Appendix D}

\section{French Composition and Composition Extended (French 33212/33214) - Spring 2016}

Webpage: http://www.personal.kent.edu/ rberrong/fr33212

Instructor: Carine Graff

Office: 307 D Satterfield

Office hours: Mondays and Wednesdays 1-2 p.m. in the Moulton Hall lobby, and by appointment.

Office phone: Please don't call. Send e-mail instead.

e-mail: cgraff2@kent.edu

\section{Texts}

Pierre Loti, Pêcheur d'Islande, available on the class webpage

Any good grammar review

A large bi-lingual dictionary. This is essential to passing this course. If you can put your dictionary in your purse, it's too small to get you through this course. (This goes for the women in the class, too;) You will need a LARGE dictionary that has examples of usage. Do not rely on an on-line dictionary. Students who have done so have not done well in this class.

You will also need a zip drive, which you will turn in to me with assignments. Make sure to put your last name on the drive in some fashion that won't come off. 


\section{Calendar}

The professor reserves the right to make alterations in the calendar.

I.

18.1. Martin Luther King Day: no class

20.1: First day of class: explanation of the website and review of passé simple

22.1: Pêcheur d'Islande, Lecture 1

II.

25.1: Lecture 2

27.1: Lecture 3

29.1: Lecture 4

31.1 Last day to withdraw without a grade of $\mathrm{W}$; last day to add

III.

1.2: Lecture 5, plus Draft 1 of First essay (details below; remember the rules for written assignments explained above: triple-spacing, etc.)On your zipdrive name the file [Your last name]1-1

3.2: Lecture 6

5.2: Lecture 7, plus Draft 1 of First essay revised. Remember, you must hand in your first effort with my annotations on it as well.Name the file [Your last name]1-1r IV.

8.2: Lecture 8

10.2: Lecture 9, plus Draft 2 of First essay (details below). Remember, you must turn in your previous drafts with my annotations on them with this draft. Name the file [Your last 
name]1-2

12.2: Lecture 10

V.

15.2: Lecture 11, Victime du jour 20, plus Draft 2 of First essay revised. Remember, you must turn in your previous drafts with my annotations on them with this draft. Name the file [Your last name]1-2r

17.2: Lectures 12-13 Victime du jour 19

19.2: Lecture 14, plus Draft 3 of First essay (details below). Remember, you must turn in your previous drafts with my annotations on them with this draft. Name the file [Your last name]1-3

VI.

22.2: Lectures 15-16, Victime du jour 18, plus Review of grammar problems from Draft 3 24.2: Lecture 17, Victime du jour 17, plus Draft 3 of First essay revised. Remember, you must turn in your previous drafts with my annotations on them with this draft. Name the file [Your last name]1-3r

26.2: Lecture 18 Victime du jour 16

VII.

29.2: Lecture 19, Victime du jour 15, plus Draft 3a of First essay (see model under Composition on the class website). Remember,you must turn in your previous drafts with my annotations on them with this draft. Name the file [Your last name]1-3a 2.3: Lectures 20-21, Victime du jour 14 plus Review of grammar problems from Draft 3a 4.3: Lecture 22, plus Draft 3a of First essay revised. Remember, you must turn in your 
previous drafts with my annotations on them with this draft. Name the file [Your last name]1-3ar

Faculty input midterm grades

VIII.

7.3: Hourly One on grammar and reading (Lectures 1-22)

9.3: Lectures 23-24, Victime du jour 13, plus Review of grammar problems from hourly 11.3: Lectures 25, plus Draft 4 of First essay. Remember, you must turn in your previous drafts with my annotations on them with this draft. Name the file [Your last name]1-4 IX.

14.3: Lecture 26, Victime du jour 12, plus Review of grammar problems from Draft 4 16.3: Lecture 27, Victime du jour 11, plus Draft 4 of First essay revised. Remember, you must turn inyour previous drafts with my annotations on them with this draft. Name the file [Your last name]1-4r

18.3: Lecture 28 Victime du jour 10

21-27.3 Spring Break

$\mathbf{X}$.

28.3: Lecture 29, Victime du jour 9, plus Draft 5 of First essay. Remember, you must turn in your previous drafts with my annotations on them with this draft. Name the file [Your last name]1-5

30.3: Lectures 30-31 Victime du jour 8

1.4: Lecture 32, plus Draft 5 of First essay revised. This is your final version of the First Essay. Remember, you must turn in all your drafts with my annotations on them with this final version. Name the file [Your last name]1final 


\section{4: Last day to withdraw}

XI.

4.4: Lecture 33 Victime du jour 7

6.4: Lecture 34, Victime du jour 6, plus Draft 1 of Second Essay (topic below). Name the file [Your last name]2-1

Once you get Draft 1 back from me with corrections and comments on it, you want to incorporate those corrections into your computer file promptly and expand it into Draft 2, which only takes a few minutes; all you have to do is arrange your six best examples in three categories and write the topic sentences for each category. Then print out Draft 2 and proof-read it on paper (no one can catch all his/her mistakes by proof-reading on a computer screen). In the days to come, and not the night before the paper is due much less that morning, work up Draft 3, etc., working on this some each day, and proof-reading each draft after you print it out on the printout. If you don't proof-read it draft by draft on the printout and incorporate your corrections as you move on to each new draft, you will never catch all your mistakes. Yes, I know, some of you will ignore this advice and leave everything until the morning the paper is due anyway, but at least you' ve been warned. To encourage you to follow my directions, however - and they will help you get a better grade - if I don't see signs of proof-reading as of Draft 3a, your grade will be lowered.

8.4: Reserved for catch up from snow days.

XII.

11.4: Lecture 35 Victime du jour 5

13.4: Lecture 36 Victime du jour 4

15.4: Lecture 37 Victime du jour 3; 
XIII.

18.4: Lectures 38-39 Victime du jour 2

20.4 Lectures 40-41, Victime du jour 1, plus completed Second Essay. Remember, you must turn in Drafts 1, 2, 3a, 4, and 5, printed out, which includes Draft 1 with my comments and corrections on it, with your completed essay. No credit for the essay without all 5 drafts. (See the comments above for how to do this.) On your zip drive you will just give me the final version, named [your name]2final.

22.4: Reserved for catch up from snow days.

XIV.

25.4: Review

27.4: Review of grammar problems from Second Essay, plus Draft 1 of Third Essay (topic blow). Name the file [Your last name] 3-1

29.4 More review of grammar problems from Second Essay XV.

2.5: Hourly Two on grammar and reading (Lectures 23-41)

4.5: Review of grammar problems from second hourly. The 12:30-1:45 section does not meet, because of Remembrance Day.

6.5: Review for final exam, plus completed Third Essay. Remember, you must turn in Drafts 1, 2, 3a, 4, and 5, printed out, which includes Draft 1 with my comments and corrections on it, with your completed essay. No credit for the essay without all 5 drafts.(See the comments above for how to do this.) On your zip drive you will just give me the final version, named [your name]3final. 
10.5: Comprehensive Final exam, part one, Tuesday, 10:15 a.m.-12:30 p.m.

13.5: Comprehensive Final exam, part two, Friday, 10:15 a.m.-12:30 p.m.

\section{ADDENDUM to the SYLLABUS (can be subject to changes)}

\section{"Lectures" questions:}

The answers to the "Lectures" questions will be handed in on a Word document, as hard copies in class. The answers need to be at least double spaced.

Compositions and compositions drafts:

The drafts for the compositions and the compositions themselves will be submitted online in a Blackboard dropbox.

You will turn in the drafts and the compositions on a triple spaced Word document. Set the language to French in Word.

This class requires regular work. You are responsible for reading the material, and submitting your work. If you feel lost, or if you need help, do not wait the last minute, come talk to me right away.

Sign and date this page and give it to your instructor by Friday of the first week of class, at the

latest. Failure to do so will result in your being deregistered from the class, so don't forget. There are other students waiting in line to get into this class who would be happy to take your place. 
I the undersigned do hereby acknowledge that I have received the syllabus for French 33212/4 and read it through to the beginning of the Calendar.

Signature:

Date: 


\section{Appendix E}

\section{Participant 1 Composition 1 Fall 2104}

Quand les auteurs écrivent en utilisant l'impressionnisme, ils utilisent beaucoup de procédés stylistiques qui rendent le texte moins clair pour laisser leurs lecteurs imaginer les choses dans le livre pour eux-mêmes. Les procédés peuvent changer entièrement ce que le sens du texte $<1>$ et si les auteurs de l'impressionnisme ne les utilisent $<1>$ pas, le sens des phrases serait très diffèrent $<2>$. Quand il a écrit le $<1>$ Pêcheur d'Islande, Pierre Loti les utilisait beaucoup pour décrire ses personnages en utilisant un style plus imaginatif. Dans cette histoire, il explique les caractéristiques physiques, les personnalités, et l'importance de chaque personnage avec les procédés et il veut que les lecteurs devinent ce qu'il veut dire. Spécifiquement, il utilise les procédés pour décrire les traits des marins, de la vierge, et de la mer.

Dans ces lectures, Loti utilise l'impressionnisme pour expliquer $<1>$ les marins moins clairs $<1>$ donc les lecteurs peuvent découvrir les personnages pour eux-mêmes, une $<1>$ exemple de ça est en $<1>1$ les phrases suivantes $<2>$. Quand Loti décrit les marins, il dit beaucoup de $<1>$ leurs âges, par exemple, il écrit $<2>$. Cette phrase me donne l'impression que les marins sont beaucoup $<1>$ d'âges différents $<2>$. Et quand il commence à expliquer $<1>$ Yann, il écrit $<2>$. Cette phrase montre que Yann est le plus grand marin $<\mathrm{NG}>$. Quand Loti compare Yann aux autres marins, il écrit $<\mathrm{NG}>$. En utilisant cette phrase, il fortifie la dernière phrase en expliquant qu'il est plus grand que les autres personnes en général $<\mathrm{NG}>$. Pour aider les lecteurs d'imaginer $<1>$ Yann, Loti décrit sa figure $<1>$, il fait ça en écrivant $<2>$. Après 
$<1>$ Loti finit de décrire la $<1>$ physique de Yann, il explique comment Yann est un bon $<1>$ homme qui oublie qu'il est très fort $<2>$. Cette phrase explique au lecteur que Yann est un très gentil homme mais souvent il utilise trop de force en jouant avec les autres $<\mathrm{NG}>$.

Dans cette histoire, Loti décrit la vierge comme une femme mystérieuse qui $<1>$ les marins envoient leurs prières, ces phrases suivantes qui sont utilisées par Loti décriront la Vierge plus $<2>$. Les phrases suivantes qui sont utilisées par Loti décriront la Vierge plus pour expliquer l'importance et le rôle de la Vierge dans les vies $<1>$ des pêcheurs $<2>$. Quand Loti introduit la Vierge au lecteur, il explique qu'elle est un symbole très importante $<1>$ des pêcheurs, il fait ça par disant $<1><2>$. Cet exemple montre que la Vierge est très importante pour les vies $<1>$ de la population de Paimpol et aussi les pêcheurs $<2>$. Pour expliquer le rôle de la Vierge plus, Loti écrit $<\mathrm{NG}>$. En écrivant ça, il explique comment les gens l'utilisent pour tous les types de prières $<\mathrm{NG}>$..

La mer est très symbolique dans ces lectures, les pêcheurs en parlent beaucoup, Loti utilise la mer dans $<1>$ beaucoup de façons, comme $<1>$ les phrases suivantes $<2>$. Quand Loti explique la scène au lecteur, il écrit $<\mathrm{NG}>$. Il a écrit ça pour montrer les $<1>$ lecteurs que les pêcheurs sont en mer, très loin de la terre $<2>$. Pour expliquer la taille de la mer, il écrit $<\mathrm{NG}>$. Il a écrit cette phrase pour aider les lecteurs d'imaginer $<1>$ juste les vapeurs sur la surface de la mer, il n'y a rien d'autre là autre $<1>$ que le bateau et les marins $<2>$.

Après que vous lisez Pêcheur d'Islande, vous aurez vu comment Loti utilise des procédés quand il décrit les personnages, spécialement les marins, la vierge, et la mer. En utilisant tous ces procédés, Loti nous force à penser à toutes $<1>$ les personnages et décider pour nous-mêmes le rôle que chaque personnage a dans l'histoire et comment les objets qu'il personnifie affectent l'intrigue et les évènements suivants $<2>$. 


\section{Appendix F}

Participant A Summary 2 Spring 2016

Au d'abord $<1>$ de l'histoire, nous rencontrons à $<1>$ la Marie et deux hommes sur le bateau $<2>$. Les deux hommes s'appellent Sylvestre Moan et Yann Gaos $<\mathrm{NG}>$. Les deux hommes sont $<1>$ marins qui pêchent au $<1>$ bord de la Marie $<2>$. Gaud et Yvonne écrive $<1>$

une lettre pour $<1>$ envoyer a Sylvestre $<2>$. Gaud et Yvonne est $<1>$ les personnes de la même famille de Sylvestre $<2>$. Ils vont au pardon des islandais $<\mathrm{NG}>$. Gaud et $\mathrm{Yann}<1>$ rencontrent pour la première fois $<2>$. Gaud tombe amoureuse avec $<1>$ Yann $<2>$. Au contraire, Yann n'intéresse $<1>$ pas à Gaud $<2>$. Tout au long d' $<1>$ histoire, Gaud aime Yann désespérément $<2>$. Il y a une tempête qui surprend l'équipe $<1>$ de la Marie en bref $<1><2>$. Eventuellement, l'équipe $<1>$ de la Marie retourne à l' $<1>$ Islande à la fin de la saison de pêcher $<1><2>$. Sylvestre et Yann vont dans des directions différentes $<\mathrm{NG}>$. Yann va à la $<1>$ ville différente que sa ville pendant sa $<1>$ vacance $<2>$. Pendant ce temps, Gaud va chez les Gaos pour faire $<1>$ les affaires de son père $<2>$. En réalité, elle va chez les Gaos pour voir Yann mais Yann n'est pas là $<\mathrm{NG}>$. Gaud confronte Yann quand il retourne $<1><2>$. Malheureusement, Sylvestre part pour faire son service militaire en Chine $<\mathrm{NG}>$. Pendant son service, Sylvestre est blesse $<1>$ par une balle $<\mathrm{NG}>$. Eventuellement $<1>$, Sylvestre est mort $<2>$. Yvonne apprend de $<1>$ la mort de Sylvestre et elle commence à se dégrader physiquement et mentalement $<2>$. Yann retourne à sa ville et il apprend de la mort de Sylvestre. Apres la mort de Sylvestre, Gaud s'occupe de Yvonne et elle essaie à $<1>$ oublier Yann $<2>$. Gaud et Yann $<1>$ rencontrent quand 
le chat de Yvonne est tué par les gamins $<2>$. Gaud et Yann ont le même souci au sujet de Yvonne $<2>$. Yann a pitié de Gaud et Yvonne et il demande à Gaud sa main à $<1>$ mariage $<2>$. Yann et Gaud épousent $<1>$ pendant le temps mal $<1><2>$. Apres qu'ils aient eu $<1>$ leurs noces, Yann part pour faire la pêche $<1>$ encore au bord de la Léopoldine et Gaud sent $<1>$ assuré pour son retour $<2>$. Quand la saison de pêcher $<1>$ est fini $<1>$, tous les autre $<1>$ bateau $<1>$ retournent $<1><2>$. La Léopoldine ne retourne $<1>$ pas et l'équipe $<1>$ de la Léopoldine considère $<1>$ mort $<2>$. 


\section{Appendix G}

\section{Lecture 11}

\section{Groupe 2}

1. Remplacez les éléments soulignés par des pronoms et donnez une explication: Yvonne a envoyé une lettre à Sylvestre.

2. Remplacez l'élément souligné par un pronom :

Yann ne réfléchit pas trop à la situation avec Gaud.

3. Comment diriez-vous en français (How would you say in French):

Sylvestre and Yann were having a lot of fun while fishing.

4. Comment s'appelle cette forme du verbe en français ? Pouvez-vous expliquer sa formation?

Yvonne pense toujours à la mort en s'endormant.

5. Complétez les blancs :

La mer est souvent (agiter), mais les morues (nager) toujours de la même façon.

6. Comment diriez-vous en français (How would you say in French) :

Loti describes Gaud and Yvonne in the same way. 


\section{Appendix H}

Pour s'entrainer à attiser la curiosité de votre lecteur (Arouse your reader's curiosity) :

Imaginez qu'Yvonne va mourir. Écrivez le paragraphe qui apparaîtra avant la fin du roman juste avant la découverte de son corps. Vous pourriez peut-être décrire le personnage approchant du corps, ou le lieu, ou les deux. Le but de l'exercice est de développer les techniques qui à la fois attirent le lecteur vers le paragraphe qui va suivre, éveillant son désir de poursuivre, et le retenant sur ce paragraphe par son propre intérêt.

(Imagine that Yvonne is going to die. Write a paragraph that will appear towards the end of the novel, right before the discovery of her body. You could perhaps describe the character discovering and coming closer to the body, or the location, or both. The goal is to develop techniques that at the same time attract the attention of your reader towards the next paragraph, triggering the desire to read more, and make the reader stop for a minute to realize what just happened.)

Contenu 12345 Grammaire 12345 Orthographe 12345 Syntaxe 12345 


\section{Appendix I}

\section{Grading scale - Composition 1}

Topic: Style analysis: Which stylistic devices does Loti use to counter the detail oriented characteristics of the language, to make pictures described by words less clear, less precise, less certain ? (At least 5 paragraphs: introduction, at least 3 paragraphs of analysis, conclusion.)

\begin{tabular}{|c|c|c|}
\hline & & After correction \\
\hline Draft 1: & $/ 20$ & \\
\hline Submitted both documents & $/ 2.5$ & \\
\hline $\begin{array}{l}9 \text { well chosen examples (Keep main } \\
\text { topic in mind) }\end{array}$ & $/ 5$ & \\
\hline Stylistic device underlined & 15 & \\
\hline Reference given & $/ 2.5$ & \\
\hline 3 well defined categories & 15 & \\
\hline Draft 2: & $/ 20$ & \\
\hline $\begin{array}{l}6 \text { well chosen examples (Keep main } \\
\text { topic in mind) }\end{array}$ & $/ 5$ & \\
\hline $\begin{array}{l}\text { The introductory sentence to the } \\
\text { category is clear and corresponds to } \\
\text { the topic of the essay, as well as to } \\
\text { the category. }\end{array}$ & $/ 5$ & \\
\hline $\begin{array}{l}\text { Spelling, grammar, and syntax } \\
\text { errors are minimal. }\end{array}$ & $/ 10$ & \\
\hline Draft 3: & $/ 20$ & \\
\hline $\begin{array}{l}\text { Respected instructions for context } \\
\text { (we should be able to picture the } \\
\text { scene in our heads when reading } \\
\text { your context sentence). }\end{array}$ & $/ 5$ & \\
\hline $\begin{array}{l}\text { Respected analysis instructions (Do } \\
\text { not repeat/restate what your example } \\
\text { already says. Keep main topic in } \\
\text { mind.) }\end{array}$ & $/ 5$ & \\
\hline $\begin{array}{l}\text { Spelling, grammar, and syntax } \\
\text { errors are minimal. }\end{array}$ & $/ 10$ & \\
\hline
\end{tabular}




\begin{tabular}{|c|c|c|}
\hline Draft 4: & $/ 20$ & \\
\hline $\begin{array}{l}\text { Generally respected the different } \\
\text { parts of the introduction. }\end{array}$ & $/ 2.5$ & \\
\hline 2 general sentences & $/ 2.5$ & \\
\hline Goes towards the topic step by step & $/ 5$ & \\
\hline $\begin{array}{l}\text { The outline of the essay is presented } \\
\text { (categories) in the last sentence. }\end{array}$ & 15 & \\
\hline $\begin{array}{l}\text { Spelling, grammar, and syntax } \\
\text { errors are minimal. }\end{array}$ & 15 & \\
\hline Draft 5: & $/ 20$ & \\
\hline $\begin{array}{l}\text { Generally respected the different } \\
\text { parts of the conclusion }\end{array}$ & $/ 2$ & \\
\hline $\begin{array}{l}\text { The first sentence reminds us of the } \\
\text { thesis. }\end{array}$ & 12 & \\
\hline $\begin{array}{l}\text { The second sentence shows personal } \\
\text { thoughts about what has been said in } \\
\text { the essay. }\end{array}$ & $/ 4$ & \\
\hline Conclusion of personal thoughts & $/ 4$ & \\
\hline $\begin{array}{l}\text { General conclusion on everything } \\
\text { that has been said. Brings up other } \\
\text { thoughts to open up the topic, and } \\
\text { triggers further research. }\end{array}$ & $/ 4$ & \\
\hline $\begin{array}{l}\text { Spelling, grammar, and syntax } \\
\text { errors are minimal. }\end{array}$ & $/ 4$ & \\
\hline
\end{tabular}




\section{Appendix J}

Grading rubric for the summary:

Syntaxe: 123456

Grammaire: 12345

\section{Contenu:}

Took into account that the reader doesn't know about the story 123

Didn’t give too many details 123

All the important events are given 123

Total: $/ 20$ 


\section{Appendix K}

Results examples for the concordance search Fall 2015 last composition.

\begin{tabular}{|c|c|c|c|}
\hline Participant & Sentence & $\begin{array}{l}\text { String } \\
\text { chosen }\end{array}$ & Results \\
\hline $\mathrm{P} \_\mathrm{a}$ & $\begin{array}{l}\text { Loti décrit une } \\
\text { autre scène où } \\
\text { Gaud endure } \\
\text { les luttes de } \\
\text { la vie. }\end{array}$ & $\begin{array}{l}\text { Les } \\
\text { luttes de } \\
\text { la vie }\end{array}$ & 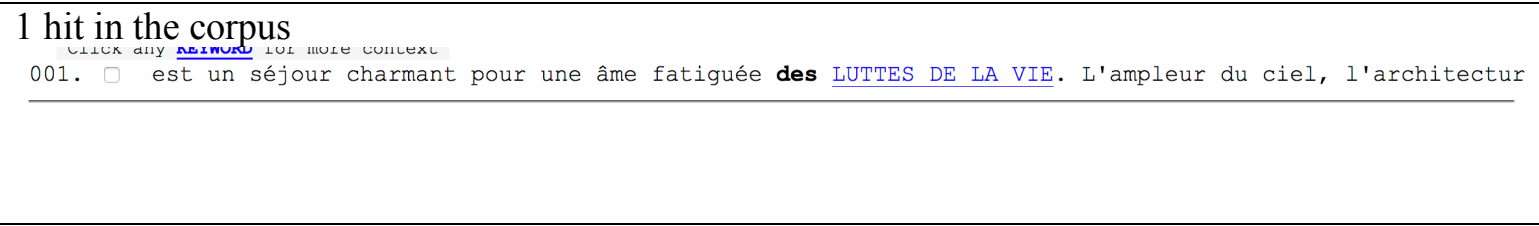 \\
\hline$P_{-} \mathrm{c}$ & $\begin{array}{l}\text { Elle devient } \\
\text { une employée } \\
\text { et pas juste } \\
\text { un joli visage. }\end{array}$ & $\begin{array}{l}\text { Pas juste } \\
\text { un }\end{array}$ & $\begin{array}{l}43 \text { hits in the corpus, but not in the context expected. } \\
229,000 \text { hits in the Google.fr search. } \\
\text { This expression is very colloquial, it is rather used in speech. Dropping the negation "ne" in "ce } \\
\text { n'est pas juste" in French is the same as saying "it ain't" instead of "It is not" in English. }\end{array}$ \\
\hline $\mathrm{P}_{-} \mathrm{d}$ & $\begin{array}{l}\text { La mort de } \\
\text { Sylvestre était } \\
\text { triste, mais il } \\
\text { y a un bon } \\
\text { côté parce que } \\
\text { Yann a trouvé } \\
\text { du bonheur } \\
\text { avec Gaud. }\end{array}$ & $\begin{array}{l}\text { Trouver } \\
\text { du } \\
\text { bonheur }\end{array}$ & 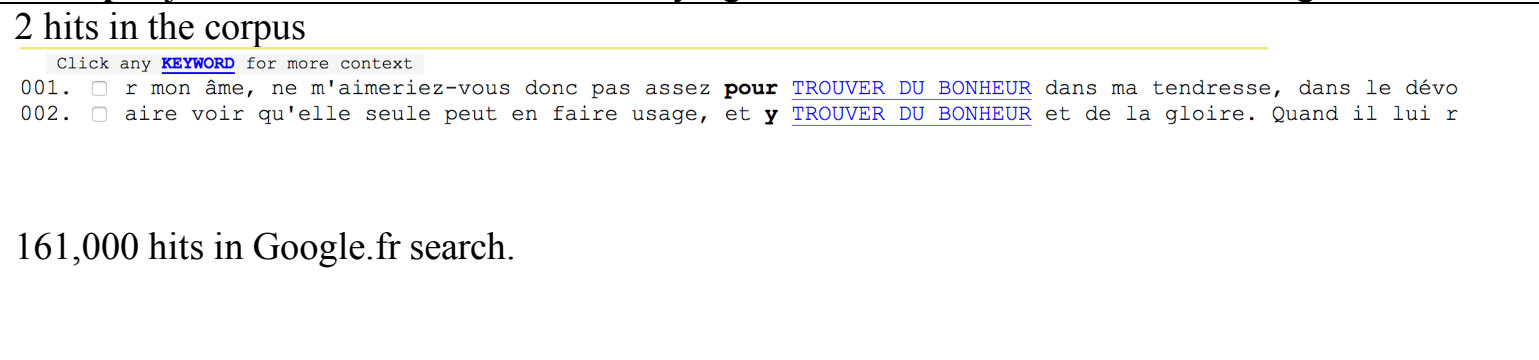 \\
\hline
\end{tabular}




\begin{tabular}{llll} 
P_f & $\begin{array}{l}\text { Sa santé } \\
\text { affecte tous } \\
\text { les } \\
\text { personnages } \\
\text { dans } \\
\text { l'histoire. }\end{array}$ & $\begin{array}{l}\text { dans } \\
\text { l'histoire }\end{array}$ & $\begin{array}{l}\text { None in the corpus } \\
\text { personnages } \\
\text { dans } \\
\text { l'histoire }\end{array}$ \\
\hline P_h & $\begin{array}{l}\text { Il montre aux } \\
\text { lecteurs } \\
\text { comment son } \\
\text { personnage a } \\
\text { changé } \\
\text { pendant le } \\
\text { roman. }\end{array}$ & $\begin{array}{l}\text { Pendant le } \\
\text { roman }\end{array}$ & $\begin{array}{l}\text { None in the corpus. 314,000 hits in the Google.fr search. } \\
\text { "Le diptyque de Castel-Forte est l'exception à cette règle, puisque le contraste qu'il crée reflète } \\
\text { une évolution, une dégradation, et au-delà, les traces de tout ce qui est arrivé à Corinne pendant le } \\
\text { roman." (Harriman-Smith, 2015, p. 139) }\end{array}$ \\
\hline
\end{tabular}




\section{Appendix L}

Results examples for the concordance search

\begin{tabular}{|c|c|c|c|}
\hline Participant & Sentences & $\begin{array}{c}\text { String } \\
\text { used }\end{array}$ & Results \\
\hline \multirow[t]{5}{*}{ P_A } & $\begin{array}{l}\text { En } \\
\text { réalité, } \\
\text { elle va } \\
\text { chez les } \\
\text { Gaos pour } \\
\text { voir Yann } \\
\text { mais Yann } \\
\text { n'est pas } \\
\text { là. }\end{array}$ & $\begin{array}{l}\text { En } \\
\text { réalité }\end{array}$ & 196 hits in the corpus \\
\hline & $\begin{array}{l}\text { Pendant } \\
\text { son }\end{array}$ & & \\
\hline & service, & \multirow{3}{*}{$\begin{array}{l}\text { blessé } \\
\text { par une } \\
\text { balle }\end{array}$} & 1 hit in the corpus \\
\hline & Sylvestre & & 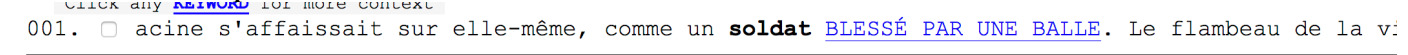 \\
\hline & par une & & 192,000 hits in the Google.fr search. \\
\hline
\end{tabular}




\begin{tabular}{|c|c|c|c|}
\hline$P_{-} \mathrm{D}$ & $\begin{array}{l}\text { Gaud est } \\
\text { fâchée } \\
\text { avec Yann } \\
\text { quand il } \\
\text { revient de } \\
\text { la mer. }\end{array}$ & $\begin{array}{l}\text { revient } \\
\text { de la } \\
\text { mer }\end{array}$ & $\begin{array}{l}\text { None in the corpus. } \\
294,000 \text { in the Google.fr search. }\end{array}$ \\
\hline P_E & $\begin{array}{l}\text { Il a fait le } \\
\text { long } \\
\text { voyage en } \\
\text { Chine, en } \\
\text { voyant } \\
\text { l'Égypte, } \\
\text { l'Inde, et } \\
\text { le } \\
\text { Vietnam. }\end{array}$ & $\begin{array}{l}\text { le long } \\
\text { voyage } \\
\text { en }\end{array}$ & $\begin{array}{l}\text { None in the corpus. } \\
73,400 \text { hits in the Google.fr search. }\end{array}$ \\
\hline \multirow[t]{2}{*}{$P_{-} F$} & \multirow{2}{*}{$\begin{array}{l}\text { Elle sait } \\
\text { que Yann } \\
\text { sera là, } \\
\text { mais il } \\
\text { vient } \\
\text { tard. }\end{array}$} & $\begin{array}{l}\text { vient } \\
\text { tard }\end{array}$ & $\begin{array}{l}2 \text { hits in the corpus } \\
001 . \square \text { en suis pas moins son esclave. - Cette courtoisie VIENT TARD, répondit Isabelle, après } \\
002 . \square \text { s-même, Repartit le vieillard. Tout établissement VIENT TARD, et dure peu. La main des }\end{array}$ \\
\hline & & $\begin{array}{l}\text { il vient } \\
\text { tard }\end{array}$ & 3,260 hits in the Google.fr search. \\
\hline \multirow[t]{2}{*}{ P_G } & $\begin{array}{l}\text { Yann rend } \\
\text { visite à } \\
\text { Yvonne } \\
\text { quand il } \\
\text { revient et } \\
\text { il } \\
\text { remarque } \\
\text { la } \\
\text { pauvreté } \\
\text { de la } \\
\text { maison. }\end{array}$ & $\begin{array}{l}\text { la } \\
\text { pauvreté } \\
\text { de la } \\
\text { maison }\end{array}$ & $\begin{array}{l}\text { None in the corpus. } \\
8 \text { hits in the Google.fr search. }\end{array}$ \\
\hline & $\begin{array}{l}\text { Il y a un } \\
\text { mariage } \\
\text { entre }\end{array}$ & $\begin{array}{l}\text { Mariage } \\
\text { entre }\end{array}$ & 9 hits in the corpus. \\
\hline
\end{tabular}


Gaud et

Yann, et

ils sont

très

heureux.
001. Vous ne pouvez avoir pour légitime femme: Il y a MARIAGE ENTRE nous accordé, Dont vous a 002. I et de sa conversion à nostre Foy, ils accordent MARIAGE ENTRE luy et Bradamante, laquel 0ut deux enfants : un garçon, puis une fille. De MARIAGE ENTRE eux, il n'en fut pas un re IV Projet de MARIAGE ENTRE Mgr le duc de Berry et la 005. 007. seule fois, me répondit-elle; alors il me dit: Le MARIAGE ENTRE nous ne serait qu'une va 008. je suis très ignorantet je sers de témoin pour un MARIAGE ENTRE Irène Adler, demoiselle, $\epsilon$ 009. $t$ comme elle vous aime si elle ne désirait pas un MARIAGE ENTRE nous ? - C est vrai, je

542,000 hits in the Google.fr search. 